\title{
Damat Ferit Paşa'nın IV. Hükümeti Döneminde Kuvâ-yı Milliye İleri Gelenleri Hakkında Verilen İdam Kararları
}

\author{
Doç. Dr. Osman AKANDERE
}

\begin{abstract}
$\ddot{O Z E T}$
Damat Ferit Paşa önceki dönemlerinde olduğu gibi IV. Sadaretinde de Kuvâ-yl Milliyecilerin tenkil edilmesi yönünde çalışmalar yürütmüştür. Öncesinde "İttihatçıllk", "Bolşeviklik", "Yalancı Milliyetçilik"le itham ettiği Kuvâ-yı Milliyecileri, IV. Sadaretinde "Hükümetin Beyannamesi", "Padişahın Hatt-ı Hümayunu" ve Şeyhülislam Dürrizâde Abdullah Efendi'ye çıkartmış olduğu "Fetvâyı Şerife" aracillğıyla etkisiz hale getirmeye çallşmış̧tır. Özellikle Dürrizâde'nin çıkardı̆̆ Fetvâ-yı Şerife aracılığıyla Mustafa Kemal Paşa ve arkadaşları; "dinsizlik", "devlete ve millete düşmanlık"la suçlanmış, nihayetinde de öldürülmelerinin "farz" olduğu Anadolu insanına duyurulmuştur. Böylelikle halkın dinî duyguları siyasî hesaplar uğruna kullanılmaya çalışılmıştır.

Damat Ferit Paşa, bütün çabalarına rağmen üstesinden gelemediği Kuvâ-yı Milliye Hareketi'ni bu sefer hukukî yönden mahkûm etme yolunda çalıșmalara girişmiştir. Öncelikle 1. Divân-ı Harbi Örfi'nin başına Nemrut Mustafa Paşa'yı getirmiş ve Kuvâ-yı Milliye Hareketi'nin lider kadrosu hakkında yargılama sürecini başlatmıştır. Illk olarak Mustafa Kemal Paşa ve arkadaşları gıyaben yargılanmışlar ve "Mülkiye Ceza Kanunname-i Hümayunu" gereğince "idamlarına" karar verilmişstir. Ardından Fevzi Paşa, onun ardından da aralarında İsmet Bey, Rıza Nur ve Hamdullah Suphi gibi önemli simalarında bulunduğu 17 kişi yargılanmıs ve "idama" mahkûm edilmişlerdir. Böylelikle Büyük Millet Meclisi'nin ilk İcra Vekilleri Heyeti üyeleri, başkanı Mustafa Kemal Paşa da dâhil olmak üzere 1. Divân-ı Harbi Örfi tarafindan idama mahkûm edilmiștir.

Mustafa Kemal Paşa ve arkadaşlarının haricinde daha pek çok kişi Kuvâ-yı Milliye'ye mensubiyetleri dolayısıyla Divân-ı Harbi Örfice çeşitli cezalara
\end{abstract}

* Selçuk Üniversitesi Eğitim Fakültesi 
çarptırllmıştır. Nihayetinde de Damat Ferit Pașa'nın "idam kararı" verdirme girişimleri başarılı olamamış, amacına ulaşamamıştır.

Anahtar Kelimeler: Kuvâ-yı Milliye Önderleri, Divân-ı Harbi Örfi, İdam, Mustafa Kemal, Damat Ferit Paşa Hükümeti

\section{Death Sentences Against The Notables of The Nationalist Forces In The Era of The Fourth Government of Damat Ferit Pasa}

\section{ABSTRACT}

Damat Ferit Pasa carried out various actions on his fourth vizierate to intimidate the Nationalist Forces as he did before. In his fourth vizierate, he tried to neutralize the Nationalist Forces that before he accused being the member of Union and Progress Party, Bolshevist and false nationalist, by "Government Declaration", "the Padisah's Decision" and "the Fatwa" of Sheikh al-Islam Dürrizade Abdullah Efendi. Especially by the "Fatwa" of Dürrizade, Mustafa Kemal Pasa and his friends were accused of "irreligiousness" and "enmity to the state and people and finally, It is announced to Anatolia that their killing is the religious duty. In this way, the religious sense of the public is tried to be used for their political benefit.

Damat Ferit Pasa tried to convict the Nationalist Force Movement legally that he couldn't cope with despite all his efforts. First of all, Nemrut Mustafa Pasa was assigned to the head of the $1^{\text {st }}$ Marital Law Court and then the judicial process against the leading staff of the Nationalist Forces was stared. At first, Mustafa Kemal and his friends were judged by the name and they are sentenced to death according to the Civil Service Law. Afterwards, 17 people including Fevzi Pasa, Ismet Bey, Riza Nur and Hamdullah Suphi were sentenced to death. In this way, Mustafa Kemal Pasa who was the chairman, and the members of the Cabinet of the Great National Assembly were sentenced to death by the $1^{\text {st }}$ Marital Law Court. Many people beside Mustafa Kemal and his friends, were sentenced because of being the Member of the Nationalist Forces by the Marital Law Court. As a result, the attempt of giving "death sentences" were not succeeded or reached its goal.

Key Words: Leaders of the Nationalist Forces, Marital Law Court, Execution, Mustafa Kemal Pasa, Damat Ferit Pasa Government. 


\section{GíRIȘ}

Damat Ferit Paşa, 1 Ekim 1919 tarihinde ayrıldı ${ }_{1}{ }^{1}$ sadaret görevine, yaklaşı yedi ay sonra 5 Nisan 1920 'de yeniden tayin edildi'. Bu tayin ile Damat Ferit Paşa IV. defa hükümeti kurmakla görevlendiriliyordu ${ }^{3}$.

Damat Ferit Paşa'nın yeniden iktidar mevkiine gelmesinde İngilizlerin Salih Paşa Hükümeti'ni düşürmeye yönelik faaliyetleri ile ${ }^{4}$ İstanbul'daki Kuvâ-yı Milliye aleyhtarlarının çabaları önemli rol oynamıştı. Bilhassa Kuvâ-yı Milliye aleyhtarı Peyam-1 Sabah ve Alemdar gibi İstanbul gazetelerinin bu çabalarda önemli rol oynadığ görülüyordu ${ }^{5}$. Öyle ki Peyam-1 Sabah'ta, daha 25 Mart 'ta "Sadaret makamının Damat Ferit'e teklif edildiğine" dair yazılar bile yazılmıştır'.

İç ve dış baskılara daha fazla dayanamayan Salih Paşa Hükümeti, 2 Nisan'da istifa etmek zorunda kald1 ${ }^{7}$. Padișahın sadarete Damat Ferit Paşa'yı görevlendirmesi bekleniliyordu. Damat Ferit Paşa'nın daha önceki iktidarları

${ }^{1}$ Damat Ferit Paşa'nın iktidardan uzak kaldığı bu süre içinde İstanbul'da önce Ali Rıza Paşa ve daha sonra da Salih Paşa Hükümetleri iş başında bulunmuşlardı.

Aslında Sadaret görevi Damat Ferit Paşa'ya tevcih edilmeden önce, Padişah Mehmed Vahdeddin tarafindan Tevfik Paşa'ya teklif edilmiş ancak Tevfik Paşa bu görevi kabul etmeyince Damat Ferit Paşa dördüncü defa bu göreve getirilmişti. Bkz. Ali Fuat Türkgeldi, Görüp İsittiklerim, Türk Tarih Kurumu Basımevi, Ankara-1949, s. 282.

Mütareke Dönemi olarak adlandırılan 1918-1922 yılları arasında beş defa hükümeti kurmakla görevlendirilmiş bulunan Damat Ferit Paşa'nın dördüncü defa kurduğu hükümet ( 5 Nisan-31 Temmuz 1920) tarihleri arasında görev yapmıștır.

${ }^{4}$ İtilaf Devletleri özellikle İngiltere, İstanbul'un resmen işgalinden sonra iş başında bulunan Salih Paşa Hükümeti'ni düşürmeye yönelik faaliyetlerini artırdılar. Bu yönde baskı yapmaya başladılar. Nitekim Yüksek Komiserler 26 Mart 1920'de verdikleri ortak bir nota ile Hükümet'ten Kuvâ-yı Milliye hareketini resmen ret ve mahkûm etmesini istediler. Salih Paşa Hükümeti bu notaya 29 Mart'ta verdiği cevapta, Anadolu'daki Kuvâ-yı Milliye namı altında yapılan hareketlerin "meşru hakların müdafaası" olduğu cevabını verdi. Bunun üzerine Yüksek Komiserler 31 Mart'ta bir nota daha vererek aynı isteklerini tekrarladılar. Buna karşılık Hükümet 1 Nisan 1920'de verdiği bir nota ile işgal kuvvetlerinin hukuka aykırı bu muamelelerini protesto etmiști. Bkz. Adnan Sofuoğlu, Kuvâ-yı Milliye Döneminde Kuzeybatı Anadolu(1919-1921), Genelkurmay Basımevi, Ankara-1994, s. 324-325; Ayrica, Bkz. Salahi R. Sonyel, Kurtuluş Savaşı ve Dış Politika, Cilt: I, 2. Baskı, Türk Tarih Kurumu Basımevi, Ankara-1987, s. 209.

5 Peyam-1 Sabah gazetesi basyazarı Ali Kemal'in bu çabalarda önemli rol oynadığını belirten Yahya Kemal, Siyasî ve Edebi Portreler kitabının Ali Kemal'i anlattığı kısmında Damat Ferit Paşa'nın dördüncü defa sadarete gelişinin tek müsebbibi olarak Ali Kemal'i görmektedir. Kitabında Ali Kemal'i o günlerin Istanbul'undaki nüfuzunu anlatırken sunları söylemektedir: “...kat'i olarak denilebilir ki, Ali Kemal olmasaydı, onun gazetesi İtilâfçılığ tekrar kuzıştırmasaydl, șevk ve cür'et vermeseydi, Ferit Paşa tekrar iktidara gelemezdi. Ali Kemal ihtirasinin ateșiyle, ikinci ve asıl yaman olan Ferit Pasa kabinesini mevki-i iktidara getirmiş yegâne adamdır”. Bkz. Yahya Kemal, Siyasî ve Edebi Portreler, Baha Matbaası, Istanbul-1968, s. 89.

${ }^{6}$ Peyam-t Sabah, 25 Mart 1336/1920, Nu: 476/10906.

${ }^{7}$ Gotthard Jaeschke, Türk Kurtuluș Savașı Kronolojisi, 2. Bask1, Türk Tarih Kurumu Basımevi, Ankara-1989, s. 97; Zeki Sarıhan, Kurtulus Savası Günlüğü, Cilt: II, Türk Tarih Kurumu Basımevi, Ankara-1994, s. 463-464; İsmail Hami Danişmend, İzahlı Osmanlı Tarihi Kronolojisi, Cilt: IV, İstanbul-1972, s. 464. 
esnasında Kuvâ-yı Milliye aleyhine yaptığı icraatları bilindiğinden, bu durum İstanbul'da bulunan vatansever kesimlerde endişeye yol açmıştı. Nitekim Meclis-i Mebusan'ın İkinci Başkanı olan Hüseyin Kazım Bey, Damat Ferit Paşa'nın tekrar sadarete getirilmemesi hususunda Padişahla yaptığ görüşmeden eli boş dönmüştü̉. Diğer taraftan Damat Ferit Paşa'nın Sadrazam olmaması için Saray'a ve Meclis'e birçok yerden telgraflar gönderilmişti". Ancak Padişah, İngilizler nezdinde "itimada mazhar olduğuna" inandığ 1 Damat Ferit Paşa'yı sadaret mevkiine getirmeye kararlı görünüyordu ${ }^{10}$.

Beklenildiği gibi Damat Ferit Paşa, 5 Nisan'da hükümeti kurmakla görevlendirilmiş ve aynı gün kurduğu hükümet, Padişah tarafindan tasdik edilmişti ${ }^{11}$. Yeni hükümetin kuruluşu Kuvâ-yı Milliye aleyhtarı çevrelerde ve İngilizler nezdinde büyük memnuniyet yaratmıştı ${ }^{12}$.

Özellikle Kuvâ-yı Milliye aleyhtarı basında yeni Hükümet sevinçle karşılandı. Peyam-1 Sabah'ta Ali Kemal, ele geçen bu firsatın iyi değerlendirilmesini istiyor ve hükümetin 1lımlı kişilerden oluşması için Sadrazam Damat Ferit Paşa'ya tavsiyelerde bulunuyordu ${ }^{13}$. Refii Cevad ise,

${ }^{8}$ Hüseyin Kazım Bey hatıralarında bu görüşmeyle ilgili olarak "Ferit Paşa'nın tekrar mevki-i sadarete getirileceğini isittim. Fakat ihtimal vermedim" seklinde Padișaha bir söz söylediğini, Padişahın da "Evet, kararımı verdim getireceğim!" dediğini belirtmektedir. Konuşmasının devamında "Ferit Paşa'nın tekrar mevki-i sadarete getirilmesi, memleket ve makam-ı saltanat için bir felaket olacaktır(...) Yine bir takım ehliyetsiz ve münasebetsiz adamları yanına toplayacak ve istibdat ile iş görmek isteyecektir" dediğini buna karş1lık olarak da Padişahın "Ferit Paşa'yı mevki-i sadarete getirmek kararını verdim ve öyle yapacă̆ım" dediğini söylediğini ve hatta "ben Rum patriğini, Ermeni Patriğini ve Hahambaşını da istersem getiririm" dediğini belirtmektedir. Bkz. Hüseyin Kazım Kadri, Mesrutiyetten Cumhuriyet'e Hatıralarım, Haz. İsmail Kara, İletișim Yayınları, İstanbul1991,s. 171-174.

${ }^{9}$ Türkgeldi, Görüp İsittiklerim, s. 278, 282.

${ }^{10}$ Mithat Sertoğlu, "Son Osmanlı Padișahı VI. Mehmet Vahideddin ”, Hayat Tarih Mecmuası, Y11:11, Cilt: 2, Sayı: 7, (1 Temmuz 1975), s 66, (61-69)

11 Damat Ferit Paşa'nın Sadarete getirilmesiyle ilgili Hatt-1 Hümayun için, Bkz. Takvîm-i Vekâyi, 5 Nisan 1336/1920, Nu: 3820; Hatt-1 Hümayun'un bugünkü dile çevrilmiş metni için, Bkz. İbnülemin Mahmut Kemal İnal, Son Sadrazamlar, Cilt: 4, 3. Bask1, Dergâh Yayınları, İstanbul-1982, s. 2040; Galip Kemalî Söylemezoğlu, 30 Senelik Siyasî Hatıralarım (Üçüncü ve Son Cilt) 1918-1922, Ülkü Matbaas1, İstanbul-1953, s. 357; Tevfik Bıyıkoğlu, Trakya'da Millî Mücadele, Cilt: II, 2. Bask1, Türk Tarih Kurumu Basımevi, Ankara-1987, s. 83-84

5 Nisan'da İngiliz Yüksek Komiseri Amiral de Robeck, İngiliz Dışişleri Bakanı Lord Curzon'a gönderdiği raporda 'İstanbul'da Damat Ferit Pașa'nın iktidara geldiğini müjdelercesine" bildiriyordu. Bu rapor metni için, Bkz. Bilâl N. Şimşir, Ingiliz Belgelerinde Atatürk, Cilt: 2, Türk Tarih Kurumu Basımevi, Ankara-1975, s. 17

3 Peyam-l Sabah, 4 Nisan 1336/1920, Nu: 486/10916; Yeni kabinenin kimlerden oluşması gerektiği konusunda sadrazam Damat Ferit'e tavsiyelerde bulunan Peyam-1 Sabah'in başyazarı Ali Kemal Bey, bir yazısında, "Kabinede Hürriyet ve İtilâfçı nazırlar istemediği, onun firkacılara karș olduğu ve kabinenin tarafsız kisilerden olușmasını istediğini" belirtiyordu. Ali Kemal'in bu tavsiye ve istekleri Refik Halit (Karay) tarafindan şöyle dile getirilmektedir: "Nihayet onun istediği oldu ve Ferit Paşa, Reşit, Fahrettin Beylerle operatör 
Alemdar'da yazdığı "Yeni Vaziyet Karşısında" başlıklı yazısında Damat Ferit Paşa'nın uygulayacağı politikaya işaret ediyor ve "Ferit Paşa Hazretleri, Köprülü Mehmed Paşa kadar şedid, Kuyucu Murad Paşa kadar tasviyekâr, Sokullu Mehmet Paşa kadar durendiş bulunacaklardır..." diyordu $^{14}$.

Damat Ferit Paşa'nın yeniden hükümet kurmakla görevlendirilmesi Kuvâ-yı Milliye cephesinde ise büyük tepkiler yaratmıştı. Bu hükümete en büyük tepkilerden birisi Mustafa Kemal Paşa'dan gelmiştir. Anadolu ve Rumeli Müdafaa-i Hukuk Cemiyeti Heyet-i Temsiliyesi adına yayınladığ 1 tamimde; işgal ve baskı altında bulunan Salih Paşa Hükümeti'nin, milletin hayati menfaatleri aleyhinde kararlar alması için İtilaf Devletleri tarafından yapılan baskılara daha fazla engel olamadığ ${ }_{1}$ için istifa etmek mecburiyetinde kaldığ 1 ve yerine Damat Ferit Paşa'nın tayin edildiği belirtiliyordu. Tamimde devamla "Hiyanet-i vataniyesi sabit olan ve düşman süngüsü ile tavzif edilen Damat Ferit Paşa ve heyetinin hiçbir surette tanınmayacağını tamim eyleriz" denilmekteydi ${ }^{15}$. Yine Hâkimiyet-i Milliye'de yayınlanan bir yazıda "Damat Ferit'in bu ülkeye yararlı değil zararlı olacă̆ $l$ " savunulmuştu ${ }^{16}$.

Gerek İstanbul'daki vatansever çevrelerin ve gerekse Kuvâ-y1 Milliye cephesinin bu hükümetten endişe duymaları boşuna değildi. Hükümet'te, Yunan ordusunun muvaffakiyeti için dua edilmesini isteyen bir Adliye Nazırı ve yine okul kitaplarındaki Türk kelimesini Osmanlı kelimesiyle değiştirtmeye çalışan bir Maarif Nazırı vardı ${ }^{17}$.

Bu hükümetin kuruluş gayesi bizatihi Padişahın 5 Nisan tarihli Hatt-1 Hümayunu'nda da açı olarak belirtilmişti. Padişah "Ehliyet ve rü'yeti" dolayısıyla Sadrazamlığa tayin ettiği Damat Ferit'ten "milliyet namı altında ika edilen iğtişaşatı" önlemesini, bu karışıklığı yaratanlar hakkında gerekli

Cemil ve Kara Sait Pașaları peşine takmıș, Babıâli'ye yeni şekilde dâhil oldu" demektedir. Refik Halid Karay, Minelbab İlelmihrab (Mütareke Devri Anıları), 2. Bask1, İnkılâp Kitabevi, İstanbul-1992, s. 228-229; Yine Alemdar'da "Nakş-1 Ber'âb" köşesindeki Aydede imzalı yazılarıyla bilinen Refik Halit Bey de 4 Nisan 1920 tarihli yazısında "ittihatçılardan hesap sorulmasını kimse önleyemez. Bundan sonra biz söyleyelim bizi dinleyiniz" diyerek, "Hürriyet ve İtilâf Fırkası'nın Hükümeti bütün kuvvetiyle destekleyeceğini" söylemekteydi. Bkz. Alemdar, 4 Nisan 1336/1920, Nu: 473-2773.

${ }_{14}$ Alemdar, 4 Nisan 1336/1920, Nu: 473-2773; Damat Ferit Paşa tarafindan kurulan yeni Hükümetle ilgili gazetelerde çıan diğer bazı değerlendirmeler için, Bkz. Vakit, 5 Nisan 1336/1920, Nu: 865.

${ }^{15}$ Tamim 13 Nisan 1336/1920 tarihli Hâkimiyet-i Milliye gazetesinde de yayınlanmıştı. Bkz. Hâkimiyet-i Milliye, 13 Nisan 1336/1920, Nu: 21; Tamim için ayrıca, Bkz. Atatürk’ün Tamim Telgraf ve Beyannameleri IV, Türk Tarih Kurumu Basımevi, Ankara-1991, s. 298299.

${ }^{16}$ Hâkimiyet-i Milliye, 13 Nisan 1336/1920, Nu: 21

${ }^{17}$ Tevfik Bıyıkoğlu, Atatürk Anadolu'da I, Türkiye İş Bankası Kültür Yayınları, Ankara 1959, s. 17; Sarıhan, Kurtuluş Savaşı Günlüğ̈̈̈, Cilt: II, s. 490. 
kanuni yaptırımların uygulanmasını ve ülkede asayiş ve huzurun yeniden sağlanmasını istiyordu ${ }^{18}$. Böylece Padişah, Kuvâ-y1 Milliye'ye karşı yürütülecek politikalar için Hükümet'e destek olacağını da ortaya koyuyordu.

Kuvâ-y1 Milliye hareketini ve bu hareketin önde gelen lider kadrosunu yok etmek gayesiyle iş başına gelen Damat Ferit Paşa ve Hükümeti, İngilizler tarafından da desteklenmekteydi ${ }^{19}$. Hatta bu Hükümetle birlikte Mütareke'de ikinci "işbirlikçilik" dönemini başlamıştı diyebiliriz ${ }^{20}$. Nitekim Damat Ferit Paşa, iktidarının daha ilk günlerinde yani 8 Nisan'da İngiliz Yüksek Komiseri Amiral de Robeck'le görüşmüş, Anadolu'daki millî hareketi yok etmek istediğini söyleyerek, İngilizlerin onaylayacağı bir şekilde çalışmaya söz vermiş ve yapacakları için ondan yardım istemişti ${ }^{21}$. $\mathrm{Bu}$ görüşmede; "milliyetçilerin" aleyhinde ferman, beyanname ve fetvaların yayınlanacağı ve bunların uçaklarla Anadolu'ya dağıttırılması için yardımcı olunması, Anzavur'un kumandasında oluşturulacak ve millî hareketi bastıracak olan kuvvetler için silah verilmesi, Hükümeti tarafından Anadolu'ya ajanlar gönderileceği ve bazı siyasi düşmanlarının tutuklanması gibi konular ele alınmışt ${ }^{22}$.

Damat Ferit Paşa, İngiliz Yüksek Komiseri Amiral de Robeck'le yaptığ1 bu görüşmenin sonucunda, Anadolu'daki millî hareketi yok etmek konusunda almayı düşündüğü tedbirler ve gerçekleştireceği faaliyetler için İngilizlerin desteğini sağlamış gözüküyordu ${ }^{23}$. Aslında bu, Kuvâ-yı

${ }^{18}$ Takvim-i Vekâyi, 5 Nisan 1336/1920, Nu: 3820; İnal, Son Sadrazamlar, Cilt: 4, s. 2051-2052.

Damat Ferit Paşa'nın kurduğu bu yeni Hükümet'te görev alan üyelerin çoğu İngilizlerin istediği adamlardan oluşmuştu. Bkz. Osman Özsoy, Saltanat'tan Cumhuriyet'e Giden Yolda Kurtuluş Savaşı'nın Perde Arkası, Aksoy Yayıncılık, İstanbul-1999, s. 296; "Damat Ferit Paşa, kendisini, yegâne kurtuluşun Ingilizlere hoș görünmek olduğuna inandırmış ve bu inancını Padişaha da aşılamıştı" bu değerlendirme için, Bkz. Şefik Okday, Büyükbabam Son Sadrazam Ahmet Tevfik Paşa, İstanbul-1986, s. 56.

20 'Sultan Vahdettin, eniştesi olan Damat Ferit Paşa'yı tekrar sadarete getirdi ve kabine 5 Nisan 1920'de ilan edildi. Böylece mütareke esnasında girişilen ikinci "işbirlikçilik" devri başladı. Bkz. H. Basri Danışman, Artçı Diplomat-Son Osmanlı Hariciye Nazırlarından Mustafa Reşit Paşa, Arba Yayınları, İstanbul-1998, s. 100.

${ }_{1}^{1}$ İngiliz Yüksek Komiseri Amiral Robeck’in bu görüşmeyle ilgili olarak kendi dıșișlerine gönderdiği belge için, bkz. Şimşir, Ingiliz Belgelerinde Atatürk, Cilt: II, s. 26-29; Sonyel, Kurtuluş Savaşı, Cilt: I, s. 211-212. Damat Ferit Paşa'nın, "dünyaya Ingilizlerin gözlü̈̆̈̈yle baktığını" ifade eden değerlendirme için, bkz. Murat Bardakçı, Şahbaba (Osmanoğullarının Son Hükümdarı VI. Mehmed Vahideddin'in Hayatı, Hatıraları, Özel Mektupları), Pan Yayınları, 1. Bask1, İstanbul-1988, s. 437.

${ }_{22}^{2}$ Simșir, Ingiliz Belgelerinde Atatürk, Cilt: II, s. 26.

23 Ingilizler, Damat Ferit Paşa'nın, milliyetçi akımlara karşı başarı kazanacağından emin olarak onu desteklemeye karar vermişlerdi. Nitekim ilk görüşmesinden üç gün sonra Amiral de Robeck'i tekrar ziyaret eden Damat Ferit Paşa, paşalık payesi vererek Balıkesir valiliğine atadığı Ahmet Anzavur'un idaresinde Kuvâ-yı Milliye'ye karşı girişilen harekât için destek istemişti. Amiral Robeck ise, Anadolu'daki ulusal harekete İngilizlerin faal bir şekilde 
Milliye'ye yönelik bir plan ve programın Padișah, Damat Ferit Paşa Hükümeti ve İngilizler tarafından el birliği ile uygulamaya konulması demekti ${ }^{24}$.

\section{I. İdam Kararları Öncesi Damat Ferit Paşa Ve Hükümetinin Kuvâ-yı Milliye Aleyhindeki Karar Ve Uygulamalart}

Damat Ferit Paşa'nın Kuvâ-yı Milliye Hareketi hakkındaki görüş ve düşünceleri IV Sadareti ile sınırlı değildir. Nitekim Damat Ferit Paşa ${ }^{25}, 19$ Mayıs 1919 tarihinde ikinci defa sadarete gelişi ile birlikte Anadolu'da Millî Mücadele yönündeki hareketlenmelerin ciddi olarak üzerine eğilmeye başlamıştır. Çünkü Mustafa Kemal Paşa'nın Samsun'a çıkışı ve İstanbul Hükümeti'nin istekleri doğrultusunda değil de Millî Mücadele'nin gelişmesi yönünde çalışmalar yapması İngilizler başta olmak üzere Damat Ferit Paşa Hükümeti'ni de tedirgin etmiştir. Mustafa Kemal Paşa'nın Samsun'a çıkışıyla birlikte gerçekleştirdiği icraatlar hem İtilaf Devletleri hem de Damat Ferit Paşa Hükümeti tarafından kuşku ile karşılanmış ve Paşa'nın hangi maksada istinaden Samsun'da olduğu General Milne tarafindan Harbiye Nezareti'nden sorulmuştur ${ }^{26}$. General Milne'ye 24 Mayıs 1919'da

katılmalarının söz konusu olamayacağını, ancak Anzavur'un kuvvetlerine askerî yardım yapılacağını, "Hükümetin yetkisine karşı hala meydan okumaya devam eden milliyetcilerin bastırılmasında sarf edilecek çabalarda İngilizlerin her türlü yardımı yapacaklarını" söylemiști. Bkz Sonyel, Kurtuluş Savașı, Cilt: I, s. 212; Amiral De Robeck'in bu görüșmeyle ilgili olarak İngiliz Dışişleri Bakanı Lord Curzon'a gönderdiği raporu için bkz. Şimşir, Ingiliz Belgelerinde Atatürk, Cilt: II, s. 29.

${ }^{24}$ Damat Ferit Paşa ve Hükümeti, Anadolu'da yeniden otorite tesis etmek için mutlaka İngilizlerle işbirliği yapmanın gereğine inanıyordu ve bu inancını Padişaha da aşılamıştı. Padişahı İngilizlerin kendisine ve Hükümetine her türlü desteği verecekleri hususunda ikna etmiști. Nitekim Tevfik Pasa ile ilgili bir çalıșmada bu konuyla ilgili olarak "Büyükbabam birçok kez Sultan Vahideddin'e Ingilizlere siğınmakla kurtuluşu beklemenin hatalı olduğunu söylemiş ve Damat Ferit Paşa'nın 'Ingilizlerden aldığı sözün' ne derece gerçek olduğunu tahkik için Ingiliz komiseriyle" görüşmüștü. Ancak İngiliz komiserinden aldığ1 cevap: "Biz Osmanl devleti ile harp halindeyiz, nasll Hükümetinize vaatlerde bulunabiliriz" ş̧eklinde olmuștu. Büyükbabam bu cevabı Padişaha bildirdiğinde, Padișah buna inanmak istemeyerek; "Bu iş o kadar gizlidir ki, sizden bile sakliyorlar demişti." Bu deyişle Damat Ferit Paşa ile İngilizler arasında bir işbirliğinin olduğunu Padişahta teyit etmekteydi. Bkz. Okday, Ahmet Tevfik Paşa, s. 51; Benzer bir anlatımda Damat Ferit Paşa'nın Sadarete getirilmesinin söz konusu olduğu günlerde Meclis-i Mebusan ikinci başkanı Hüseyin Kazım Bey, Mabeyn Baş Kâtibi Ali Fuat Bey'e "Eğer Ferit Paşa Ingilizlerden kuvvetli bir söz almış ise, Zât-l şâhâne kendisini sadarete getirsin, biz de elbirliği ile çalısırız. Fakat böyle bir söz almamıs ise kendisinin sadareti memleketçe pek fena tesir hâsıl edeceğinden bunu yapmasın" demişti. Ali Fuat Bey'in bu sözleri Padişaha nakledildiğinde, Padişahın cevabı "evet" olmuştu. Bu anlatım için, bkz. Türkgeldi, Görüp İşittiklerim, s. 260.

${ }^{25}$ Damat Ferit Paşa hakkında tafsilat için, Bkz. Ş. Can Erdem, Sadrazam Damat Ferit Pașa, Marmara Üniversitesi Türkiyat Araștırmaları Enstitüsü, Yayınlanmamıs Doktora Tezi, İstanbul-2002, s. 1-214; İnal, Son Sadrazamlar, Cilt: 4, s. 2029-2094; Türkgeldi, Görüp İşittiklerim, s. 195-249, 261-265; Cevdet Küçük, "Damat Ferit Paşa”, İslam Ansiklopedisi, Diyanet Vakfi Yayınları, Cilt: 8, İstanbul-1993, s. 436-439.

${ }^{26}$ General Milne'nin yazısı şöyledir: “...Dokuzuncu Ordunun bir teşkilât icabı olarak lâğv edildiği anlaşılmışken Dokuzuncu Ordu Kıtaatına bir Müfettiş-i Umumi ve Dokuzuncu 
verilen cevapta; merkezden verilen emirlerin ne derece yerine getirildiğini görmek, geniş bir bölgeye dağılmış olan askerî birliklerin hareketlerini denetlemek ve bölgenin asayişini temin etmek maksadıyla tıpkı Konya'da ihdas olunan Yıldırım Kıtaatı Müfettişliği gibi Üç ve On Beşinci Kolordular için de Dokuzuncu Ordu Kıtaatı Müfettişliği'nin ihdas olunduğu belirtilmekteydi ${ }^{27}$. Fakat İstanbul tarafindan verilen bu cevap İngilizleri tatmin etmemiş ve İngilizler, Mustafa Kemal Paşa ve heyetinin derhal İstanbul'a geri çağrılmasını talep etmişlerdir ${ }^{28}$. Bunun üzerine Harbiye Nezareti'nce çekilen telgrafta; "maiyet-i âliyelerindeki istimbotlardan biri ile buraya teşrifleriniz rica olunur" 29 denilerek Mustafa Kemal Paşa ve heyetinin İstanbul'a geri dönmesi istenmiştir. Mustafa Kemal Paşa'nın geri dönmeye yanaşmaması İngilizlerin İstanbul Hükümeti'ni bu hususta baskı altına almasına sebebiyet vermiş, İstanbul Hükümeti de bu baskılardan kurtulmak için Mustafa Kemal Paşa'yı İstanbul'a geri dönmesi hususunda ikna etmeye çalışmış bunu sağlamak amacıyla birçok telgraf çekilmiş ${ }^{30}$ fakat sonuç alınamamıştır. Nihayet Mustafa Kemal Paşa'nın mevcut durumu 23 Haziran'da Meclis-i Vükelâ'da görüşülmüş; hakkındaki şikâyetler hususunda dinlenilmesi için İstanbul'a gelmesi Harbiye Nezareti'nce kendisine bildirildiği halde yapılan daveti kabul etmemesi ve Anadolu halkını hükümete karşı kışkırtması gibi sebeplerden dolayı hemen görevinden alınarak yerine daha önce Bahriye Nazırı olan Hurşit Paşa'nın tayini için gerekli olan işlemlerin yapılması için Harbiye Nezareti, Mustafa

Ordu için dahi bir Erkan-ı Harbiye reisi ile büyük bir Erkân-ı Harbiye Heyetinin neden dolayı Sivas'a izam olunmakta olduğunun anlaşılamadığını zât-ı âlinize iş'âr eylemekle mübahiyim.

Bi zabitanin ne gibi vezaif ifa edeceklerinin ve mütesavver tensikat mahivetinin neden ibaret olduğunun lütfen izah buyrulmasını istirham eylerim". Bkz. Harp Tarihi Vesikaları Dergisi (HTVD), Say1: 1, Vesika No: 15, Genelkurmay Basımevi, Ankara-1952.

${ }_{27}$ HTVD, Sayi: 1, Vesika No: 16.

${ }^{28}$ General Milne, Harbiye Nezareti'ne 6 Haziran 1919 tarihli yazısında “...Kemal Paşa ile maiyeti erkânının derhal İstanbul'a avdeti için emir buyurmalarını talep eylerim" demektedir. Bkz. HTVD, Sayı: 1, Vesika No: 17.

${ }^{29}$ HTVD, Sayı: 1, Vesika No: 19; Mehmet Arif Bey, Anadolu Ínkılâbı Millî Mücadele Anıları (1919-23), Yayına Hazırlayan: Bülent Demirbas, İkinci Basım, Arba Yayınları, İstanbul-1992, s. 26; Mustafa Kemal Paşa "geri çă̆rılma" hususunda Kazım Karabekir Paşa'yı bilgilendirmiştir. Karabekir'e çektiği telgrafta; Harbiye Nezareti'nin telgrafını dikkate sunmus ve sebeb-i davetini Cevad Paşa'dan mahrem sorduğunu ve "zât-ı âlileri gibi klymetli bir generalin Anadolu vilayetlerinde dolaşmasının efkâr-l umûmiyeye iyi bir tesir bahşedemeyeceğinden bahisle İstanbul'a celp buyurulmanız İngilizler istedi" cevabın aldığını söylemiştir. Bkz. Askerî Tarih Belgeleri Dergisi (ATBD), Sayı: 79, Belge No: 1731, Genelkurmay Basımevi, Ankara-1981; Kazım Karabekir, İstiklal Harbimiz, Cilt: 1, Emre Yayınları, İst-1995, s. 173.

${ }^{30}$ Mesela 15 Haziran 1919 tarihli telgrafta; “Ístanbul'a davetiniz Hükümet-i Seniyyenin kararı neticesidir" denilmektedir. Bkz. HTVD, Say1: 1, Vesika No: 22; Yine 7 Temmuz 1919 tarihli Babıâli'den Ferit imzasıyla Samsun'a yazılan bir telgrafta da; “...Mustafa Kemal Pașa ĕger vatanını seviyorsa onun faydası için dönmelidir...” denilmektedir. Bkz. Karay, Minelbab ilelmihrab, s. 186. 
Kemal Paşa'nın hiçbir sıfat-1 resmiyesi kalmadı̆̆ından emirlerinin resmi geçerliliğinin bulunmadığının bütün vilayetlere tebliği hususunda da Dâhiliye Nezareti görevlendirilmiştir ${ }^{31}$. Dâhiliye Nazırı Ali Kemal Bey de hemen aynı gün vilayetlere gönderdiği gizli tamimde; Mustafa Kemal Paşa'nın büyük bir asker olmakla beraber "zamanın siyasetine ayak uyduramadı̆̆ın" ve İngiliz mümessil-i fevkaladesinin de ssrarı ile azledildiğini, İstanbul'a celbinin ise Harbiye Nezareti'ne ait bir vazife olduğunu bildirmekteydi ${ }^{32}$. Bundan sonra, Dâhiliye Nezareti, bölgedeki askerî ve mülkî erkânın Mustafa Kemal Paşa'ya itimat etmesi ve ona yardım etmesinden dolayı olsa gerek 29 Haziran'da Sivas vilayetine gönderdiği bir telgrafta "Mustafa Kemal Paşa'yı suret-i kat'iyede ma'zûl tanımanızı tebliğ eylerim" deme gereği duymuştur ${ }^{33}$. Ancak, Hükümetin almış olduğu bu "azil" kararını Harbiye Nazırı'nın imzalayıp Babıâli'ye göndermesi ve Sadaretçe de onaylanması gerekmekteydi. Fakat Harbiye Nazırı bu kararı Babıâli'ye göndermedi ve resmî olarak Mustafa Kemal Paşa'nın azli gerçekleşemedi $^{34}$. Bu durum Dâhiliye Nazırı Ali Kemal Bey ile Harbiye Nazırı Şevket Turgut Paşa arasında kavgaya sebebiyet vermiş, Paşa ve Ali Kemal Bey'in istifası ile sonuçlanmıştı ${ }^{35}$. Neticede Şevket Turgut Paşa'dan boşalan Harbiye Nezareti'ne Mustafa Kemal Paşa'yı azletmeyi kabul eden Ali Ferit Paşa atanmıştır ${ }^{36}$. Yeni Harbiye Nazırı da, öncekiler gibi, Mustafa Kemal Paşa'nın İstanbul'a avdetini sağlayabilmek için çalıştı fakat bütün çabalara rağmen Paşa'nın İstanbul'a dönüşü sağlanamadı. Nihayet Mustafa Kemal Paşa 7-8 Temmuz gecesi Yıldız Sarayı tarafindan telgraf başına çağrılmış ve "orada giriştiğiniz değerli teşebbüsler, her nasılsa İngilizlerce vatan müdafaası şeklinde değil, başka bir şekilde anlaşılmasindan dolayl, Hükümet üzerinde şiddetli baskılar yapılmaktadır. Bununla beraber, vatan menfaati düşüncesiyle yaptığınız girişimler, devletin esas menfaatlerini

${ }_{32}^{31}$ BOA, $M V, 216 / 54$.

32 M. Kemal Atatürk, Nutuk (1919-1927), Yayına Hazırlayan: Zeynep Korkmaz, Atatürk Araștırma Merkezi Yayınları, Ankara-2005, s. 22; Ali Fuat Cebesoy, Millî Mücadele Hatıraları, Temel Yayınları, İstanbul-2000, s. 98; Refik Halit de eserinde 23 Haziran'da Ali Kemal'in kendisini çağırdığını ve “-Üçüncü Ordu Müfettişi Mustafa Kemal Paşa'nın dün akșam Meclis-i Vükelâ'da posta umuruna müdahalesinden dolayı azline karar verildi. Artık mazuldür; merakize bildiriniz, bizi haberdar etsinler ve muâmelâtın müteessir olmamasına itina göstersinler!" dediğini, kendisinin de aldığı bu emri bütün baş müdüriyetlere tamim ẹttiğini oradan da vilayâta tebligatta bulunulduğunu yazmaktadır. Bkz. Karay, Minelbab İlelmihrab, s. 170; Atatürk'ün Söylev ve Demeçleri I-IIII, Cilt: 1, Atatürk Araştırma Merkezi Yayınları, Ankara-1997, s. 19; Mevlanzade Rifat, Ittihat Terakki Iktidarı ve Türkiye İnkılâbının İç Yüzü, Yedi İklim Yayınları, İstanbul-1993, s. 298-299.

${ }^{33}$ BOA, DH. ŞFR. 100/203.

${ }^{34}$ Karay, Minelbab İlelmihrab, s. 170.

${ }^{35}$ Karay, Minelbab İlelmihrab, s. 172-173.

${ }^{36}$ Karay, Minelbab İlelmihrab, s. 174. 
bozacak ve ülkeyi büyük tehlikeler içine atacaktır" ${ }^{37}$ denilmiş ve telgraf muhaberesi sonucunda anlaşma sağlanamaması neticesinde kendisine azledildiği bildirilmiştir" ${ }^{38} 8$ Temmuz'da çıkarılan "Iradei Seniyye"39 ile Mustafa Kemal Paşa'nın Üçüncü Ordu Müfettişliği'ne son verilmiş ve azil iradesi 13 Temmuz'da Takvim-i Vekâyi'de yayınlanmıştır ${ }^{40}$. Ayrıca Mustafa Kemal Paşa'nın yakın arkadaşı olan ve kendisi ile Samsuna çıkan Refet Bey de 13 Temmuz'da azledilmiştir ${ }^{41}$. Mustafa Kemal Paşa 8 Temmuz tarihli telgraf görüssmesi neticesinde azledildiği kendisine bildirilince hemen o vakit "sarayı ve hükümeti Ingilizlere karşı zor durumda bırakmamak için askerlik mesleğinden fedakârlık ettiğini" belirterek istifa etmiştir ${ }^{42}$. Bundan sonraki durumu hakkında Mustafa Kemal Paşa Nutuk'ta şu bilgileri vermektedir: "Durum, tarafimdan, ordulara ve millete duyuruldu. Bu tarihten sonra resmî sıfat ve yetkilerimden slyrılmış olarak, yalnız milletin sevgi ve fedakârlı̆̆ına güvenerek ve onun tükenmez feyiz ve kudret kaynağından ilham ve güç alarak vicdanî görevimize devam ettik..." ${ }^{43}$ Damat Ferit Paşa Hükümeti’nin Mustafa Kemal Paşa üzerindeki faaliyetleri azille sinırlı kalmayarak taşıdığ 1 nişanların geri alınmasına ve üstündeki Fahri Yaverlik rütbesinin de kaldırılmasına kadar varmıştır ${ }^{44}$. Fakat Mustafa Kemal Paşa, Divân-1 Harp’te

${ }^{37}$ Atatürk ile İlgili Arşiv Belgeleri (1911-1921 Tarihleri Arasına Ait 106 Belge), Başbakanlık Osmanlı Arşivi Daire Başkanlığı Yayını, Ankara-1982, Belge No: 51, s. 50, 158.

38 Yıldız Sarayı tarafından Mustafa Kemal Paşa'ya çekilen telgraf şöyledir: "Memuriyet-i aliyelerinde hasbelicab hitam verilmiş olduğundan hemen bilâ teahhür Dersaadet'e avdetleri iradei kat'iyei Hazreti Pâdisahî iktizasındandır efendim. / Serkatibi Hazreti SSehriyâri Ali Fuat", Bkz. Karay, Minelbab İlelmihrab, s. 181; 8 Temmuz 1335/1919 tarihli Heyet-i Vükelâ kararında da Mustafa Kemal Paşa'nın azli istenmistir. Bkz. BOA, DUIT, 68/13; Azille ilgili ayrıca, Bkz. M. Müfit Kansu, Erzurum'dan Ölümüne Kadar Atatürk'le Beraber, Cilt: 1, Türk Tarih Kurumu Basımevi, Ankara-1986, s. 38; Atatürk, Nutuk, s. 33; Karabekir, Ístiklal Harbimiz, Cilt: 1, s. 222; Mehmet Arif Bey, Anadolu İnkılâbı, s. 29; Zekeriya Türkmen, Yeni Devletin Şafă̆ında Mustafa Kemal (Ekim 1918Ocak 1920), Atatürk Araştırma Merkezi Yayınları, Ankara-2002, s. 132-133.

${ }^{39}$ Atatürk İle İlgili Arșiv Belgeleri, Belge No: 53, s. 51, 159.

${ }^{40}$ Takvim-i Vekâyi, 13 Temmuz 1335/1919, Nu: 3596.

${ }^{41}$ İstanbul Hükümeti, 13 Temmuz'da Refet Bey’i azletmiş ve yerine Harbiye Dairesi Reisi Miralay Selahattin Bey'i tayin etmiştir. Bkz. Takvim-i Vekâyi, 17 Temmuz 1335/1919, $\mathrm{Nu}: 3600$

${ }^{42}$ Telgraf metni için, Bkz. Atatürk İle Illgili Arssiv Belgeleri, Belge No: 54, s. 51-52, 160; Karay, Minelbab İlelmihrab, 192-193; ATBD, Say1: 79, Belge No: 1735; Yurdun dört bir yanına gönderdiği 8 Temmuz tarihli bir diğer telgrafinda da "Bundan sonra gaye- $i$ mukaddese-i milliyemiz için her türlü fedakarlıkla çalısmak üzere sine-i millette bir ferd-i mücahit suretiyle bulunmakta olduğumu tekmil Müdafaa-yı Milliye ve Redd-i İlhak Cemiyetleri'ne ve merakiz-i mülkiye ile ahz-ı asker şuabatı vasıtasiyla vatanın en ücra kössesine kadar tebliğ ve ifhamina tavassut ve delalet-i seria-yl vatanperveranelerini hassaten rica ederim" demektedir. Bkz. ATBD, Say1: 79, Belge No: 1734; Cebesoy, Milli Mücadele Hatıraları, s. 122.

${ }^{43}$ Atatürk, Nutuk, s. 33.

${ }^{44}$ BOA, DUIT, 68/13; Mustafa Kemal Paşa'nın nişanlarının geri alınması ve Fahri Yaverlik rütbesinin kaldırılması hakkında tafsilat için, Bkz. Atatürk İle İlgili Arşiv Belgeleri. Belge No: 58, 58/a, 59, 60, s. 54-57, 164-166; Türkmen, Yeni Devletin Şafağında, s. 145146; Ayrıca Alemdar gazetesindeki bir haberde, "Mustafa Kemal Paşa'nın harekât-l gayr-l 
yargılanmadığı için, nişan ve madalyalarının geri alınması bir yarg1 kararına bağlı olmayıp keyfî bir hareket arz ediyordu. Üstelik Mustafa Kemal Paşa askerlikten çıkarılmayıp istifa etmiş olarak kabul edilmişti. Bu yüzden istifa eden ve istifası kabul edilmiş olan bir askerin nișan ve madalyalarının geri alınması uygun değildi. Nitekim 4 Şubat 1920 'de Ali Rıza Paşa Hükümeti tarafindan Mustafa Kemal Paşa'nın nişan ve madalyaları geri iade edilmiştir ${ }^{45}$.

Damat Ferit Paşa, üçüncü sadareti döneminde Kuvâ-yı Milliye'ye yönelik faaliyetlerini ve suçlamalarını daha da şiddetlendirmiştir ${ }^{46}$. Mesela Dâhiliye Nazırı Adil Bey tarafından Trabzon Valisi Galip Bey'e 23 Temmuz 1919 tarihinde gönderilen ve "Hükümet-i Seniyye'nin, vatanın kurtuluşunun mütareke hükümlerinin tamamen uygulanmasıyla mümkün olacağına inandığını, bunu anlayamayan sorumsuz kişilere değer verilmemesi gerektiğ $\imath^{\prime, 47}$ yönündeki telgraf, İstanbul Hükümeti'nin hem Mütareke Dönemi'ndeki siyasetini hem de Kuvâ-yı Milliye'ye bakışını göstermesi

meşruasına iştirak eden Bahriye Nazırı Esbakı Rauf Bey'in de rütbe ve nişanlarının ref" edileceği istihbar edilmektedir. Bkz. Alemdar, 14 Ağustos 1335/1919, Nu: 142-1542.

BOA, DUIT, 68/21; ATBD, Say1: 82, Belge No: 1793, Genelkurmay Basımevi, Ankara-1981; Damat Ferit Paşa döneminde Sultan Vahdettin tarafından görevinden azledilen ve nișan ve madalyaları alınan Mustafa Kemal Pașa, Ali Rıza Pașa Hükümeti döneminde nişan ve madalyalarının geri verilmesi ile karşılaşmıştır. Bu durum Sultan Vahdettin açısından düșündürücüdür. Çünkü 8 Temmuz'da azledildiğini bildiren İrade-i Seniyye'yi imzalayan Sultan Vahdettin, 4 Subat 1920'ye gelindiğinde Mustafa Kemal Paşa'y1 istifa etmis olarak kabul etmektedir. Bu durum Hükümetlerin Vahdettin'i ne kadar etkileri altına aldıklarının da bir göstergesidir. Ali Rıza Hükümeti'nin böyle bir yola başvurmasındaki temel amaç ise, Anadolu ile iyi ilişkiler geliştirmek adına bir adım atmak, karşı taraftan bunun olumlu neticelerini almak suretiyle Ảnadolu'yu İstanbul'a raptetmeyi sağlamaktır. (Y.N.-Yazarın Notu-).

${ }^{6}$ Çünkü Kuvâ-yı Milliye Hareketi gün geçtikçe daha güçlenmektedir. Her yerden her çevreden kuvâ-yı Milliye'ye katılımlar gerçekleşmektedir. Kuvâ-yı Milliye'ye iltihak edenlerden bazıları şunlardır: 27. Tümen Eski Kumandanı Albay Kara Vasıf Bey, Washington Eski Sefiri Alfred Rüstem Bey, Eski Sıhhiye Müdürü Dr. Adnan Bey (Adıvar), Halide Edip Hanım (Adıvar), 61. Tümen K. Piyade Albay Kazım Bey (Özalp), Eski Harbiye Nazırı Kavaklı Fevzi Paşa (Çakmak). Bkz. Hamdi Atamer, "Kuvâ-yı Milliye'ye Katılanların Listesi”, Belgelerle Türk Tarihi Dergisi, Sayı: 4, Ocak-1968, s. 4-9; Rıfat Paşa, Hüsnü Paşa, Abdurrahman Seref Bey, Meshur Sair Mehmet Akif Bey (Ersoy), Vehip Pașa, Akșam Gazetesi Yazarlarından Falih Rıfkı Bey (Atay), Genelkurmay İkinci Başkanı Kazım Paşa. Bkz. Hamdi Atamer, "Kuvâ-yı Milliye'ye Katılanların Listesi", Belgelerle Türk Tarihi Dergisi, Say1: 5, Subat-1968, s. 4-7; Eski Balıkesir Mutasarrıfi Hacim (Muhittin Carıkl1). Bkz. Hamdi Atamer, "Kuvâ-yı Milliye'ye Katılanların Listesi”, Belgelerle Türk Tarihi Dergisi, Say1: 6, Mart-1968, s. 9-12; Vakit Gazetesi Müdürü İsmail Ramiz Bey, Tasvir-i Efkar Gazetesi sahibi Ebüzziya Zade Talha Bey. Bkz. Hamdi Atamer, "Kuvâ-y1 Milliye’ye Katılanların Listesi”, Belgelerle Türk Tarihi Dergisi, Sayı: 7, Nisan-1968, s. 24-27; Albay Selahattin Bey, Albay Fahrettin Bey (Altay), Albay İsmet Bey (İnönü), Albay Bekir Sami Bey, Yusuf İzzet Paşa, Hamdullah Suphi Bey (TaNuı̈ver), Rıza Nur Bey, Hakkı Behiç Bey, Yusuf Kemal Bey (Tengirşek), Ankara Müftüsü Rifat Efendi. Bkz. Hamdi Atamer, "Kuvâ-yı Milliye'ye Katılanların Listesi”, Belgelerle Türk Tarihi Dergisi, Sayı: 8, Mayıs-1968, s. 811.

\footnotetext{
${ }^{47}$ Erdem, Sadrazam Damat Ferit Paşa, s. 123.
} 
bakımından mühimdir. Dâhiliye Nazırı Adil Bey tarafından 26 Temmuz'da bu kez bütün vilayetlere gönderilen bir diğer telgrafta ise yine üstü kapalı olarak Kuvâ-yı Milliye hedef alınmakta ve "...müşkülât-ı mevcûdeyi tezyîd edecek her türlü harekâtın selâmet-i vatanı tehlikeye ilgâ edeceği derkâr olduğundan bazı mahallerde vukû'ı kemâl-i teessüfle haber alınan tahrikâta karşı îcâp edenlerin ikâzı ve muktezâ-yl hâl ve mahalle göre lâzım gelen tedâbirin cihet-i mülkiye ve askeriyece müttehiden ittihâzı ehemmü elzemdir" ${ }^{48}$ denilmekteydi.

Damat Ferit Paşa Hükümeti'nin Kuvâ-yı Milliyecileri suçlayıcı ve halk nazarındaki itibarlarını zedeleyici faaliyetlerinden birisi, onları "İttihatçılık"la suçlamasıdır. Çünkü İttihatçılar, devleti gereksiz yere Birinci Dünya Harbi'ne sokmak ve milletin istikbaliyle oynamakla suçlanıyorlard1 ${ }^{49}$. Gerçekten de Kuvâ-yı Milliye'nin lider kadrosunu oluşturan şahıslardan başta Mustafa Kemal Paşa olmak üzere- bir kısmının evveliyatında İttihatçılarla bağlantısının olması, Damat Ferit Paşa Hükümeti tarafindan büyük bir firsat olarak telâkki edilmiş, bu yolla halkın Kuvâ-yı Milliyecilere düşman olması sağlanmaya çalışılmış ve bu yönde büyük gayret sarf edilmiştir ${ }^{50}$. Nitekim mezkûr Paşa'nın bu teşebbüslerine İstanbul basınından bazı gazetelerde destek vermiş ve "İttihatçılık" suçlaması adı altında büyük bir karalama kampanyasının içerisine girilmiştir ${ }^{51}$. Meselâ 1 Kasım 1919 tarihli Alemdar Gazetesi'nde Refii Cevad imzalı "Ha Şöyle Biraz Yola Gelin" adlı makalede "Harekât-ı Milliye'de Ittihatçı dolabı görmek istemeyiz" ${ }^{52}$ denilmekte ve ittihatç1lar ciddi bir şekilde eleştirilmektedir.

${ }^{48}$ Alemdar, 27 Temmuz 1335/1919, Nu: 124-1524.

Mesela Ali Kemal, "Kimi Aldatiyorlar" adl makalesinde İttihatçların Harbi Umûmi'ye giriş noktasındaki tavırlarını şöyle dile getirmektedir: “...Bu millet anlamad, ögrenmedi mi ki uçak hin-i hacette her firildağa gelir, hatta ecnebi parmağıyla da düşer, kalkar, yanar, tutuşur, uçağın kahramanları Enver, Talat, Cemal değil midir ki daha Harb-i Umûmî zuhûr eder etmez Almanya ile hafì bir muahede akd eylediler, ve milleti, ikbalini, istikbalini düsünmeden, tașinmadan ecnebî bir devletin ihtirasına kurban ettiler..." Bkz. Peyam, Ali Kemal, "Kimi Aldatıyorlar”, 28 Eylül 1335/1919, Nu: 297-55.

${ }^{0}$ Sivas Kongresi'nin toplandığı günlerde Tan Gazetesi muhabirinin Damat Ferit Pașa'ya, Mustafa Kemal Pașa ve hareketinin mahiyeti hakkında yönelttiği suale, Pașa: Harekât-1 Mezkure'nin askerî mahiyeti haiz olmadığını ve millî bir esasa da müstenid bulunmadığını ve bir saman alevinden ve İttihat ve Terakki teşvikatından ibaret olduğunu beyan etmistir. Bkz. Alemdar, 5 Eylül 1335/1919, Nu: 164-1564; Muhaliflerden Mevlanzade Rifat'ta eserinde "Ittihat ve Terakki erkânından olan ve bu günkü cumhuriyetin kurucusu ve reisi" gibi cümleler kullanmakta ve Mustafa Kemal Paşa ve arkadaşlarını "İttihatçılık"la itham etmektedir. Bkz. Mevlanzade Rıfat, Türkiye Ínkılâbının İç Yüzü, s. 252-254.

${ }^{51}$ Şüphesiz burada zikredilmesi gereken başlica gazeteler, Alemdar, Peyam, Sabah, Türkçe İstanbul ve Peyam-l Sabah'tır.

52 Alemdar, Refii Cevad, "Ha Şöyle Biraz Yola Gelin", 1 Teşrin-i Sani (Kasım) 1335/1919, Nu: 320-2621; İttihatçılık suçlamaları ile ilgili bir diğer makalede de; İzmir'i kurtaracak olanların Sivas'ta, Ankara'da Trabzon'da toplanmak yerine Aydın, Nazilli ve Akhisar gibi yerlerde toplanmaları gerektiği vurgulanmakta ve burada da Kuvâ-yı Milliye İttihatçı bir hareket olarak nitelendirilmektedir. Bkz. Alemdar, Oğuz Tekin, "Harekât-1 
Refik Halit de "Türediler ko, aksınlar üzerimden sel gibi: Ne șehrimde yerleşsinler, ne bahçemde ziftlensinler, ne içimde köklensinler... Her tarafta veba çıksın, tufan aksın, yangın geçsin, razıyım; Ittihadı istemem; bu tavafta delilimi bezirgândan beklemem" 53 diyerek tavrını net olarak ortaya koyuyordu. Refik Halit bir diğer makalesinde de "İttihat sürüsünden yeni çobanbaşı, millet paşası $m \iota$ sizi seçip ayırdı" ${ }^{\prime 54}$ demekte ve bu makalede direkt olarak Mustafa Kemal Paşa'yı hedef almaktadır. "Ittihatçıllık" suçlamalarında ilginç bir nokta ise İtilaf Devletleri de Kuvâ-yı Milliye hareketini ittihatçıların bir uzantısı olarak görmektedirler. Mesela, Amiral De Robeck, Lord Curzon'a gönderdiği bir raporda "Itttihatçıların evladı olan Mustafa Kemal ile müzakere ümitsizdir" ${ }^{55}$ demekte ve bu da İtilaf Devletlerinin Kuvâ-yı Milliye'yi nasıl değerlendirdiklerini göstermektedir.

Görüldüğü gibi Mustafa Kemal Paşa ve arkadaşları gerek İstanbul Hükümeti ve gerekse İtilaf Devletleri tarafindan kati surette tasfiye edilmesi gereken "İttihatçı kalıntıları" olarak görülmektedir. Hatta bu mücadelenin İttihatçların bir tertibi olduğunu düşünmektedirler ${ }^{56}$. Nitekim Takvim-i Vekâyi'de yayınlanan bir beyannamede de; “...Istanbul'da hafiyyen Anadolu'da müsellahen Kuvâ-yı Milliye namıla icra-yı faaliyet eden ittihat komitesi...."57 denilmektedir. Konumuzla doğrudan alakalı olmamakla birlikte Mustafa Kemal Paşa ve arkadaşlarının "İttihatçı" olup olmadıkları hususunda kısa bir bilgi vermek yerinde olacaktır. Şüphesiz bilinen bir gerçekliktir ki gerek Mustafa Kemal Paşa olsun ve gerekse Kuvâ-yı

Milliye ve İttihatçılar”, 8 Teşrin-i Sani (Kasım) 1335/1919, Nu: 327-2628. Ayrıca Bkz. Alemdar, Refii Cevad, "Harekât-1 Milliye ve İttihat ve Terakki", 6 Teşrin-i Evvel (Ekim) 1335/1919, Nu: 295-2595.

Alemdar, Kirpi (Refik Halit), “Anadolu Diyor ki”, 8 Teşrin-i Sani (Kasım) 1335/1919, Nu: 327-2628; Nitekim Yahya Kemal de hatıratında Ali Kemal'den bahsederken "O günlerin en zehirli ithamı "ittihatçı" ithamı idi; ortalığı fazla itham edebilmek için "ittihatçı" sıfatını herkese yapışırııordu" demektedir. Bu da ittihatçılığın insanların aklında ne derece vahim çağrışımlar yaptığını göstermektedir. Bkz. Beyatlı, Siyasî ve Edebî Portreler, s. 87.

${ }^{54}$ Alemdar, Aydede (Refik Halit), “Topuna Hoş Amedi”, 2 Şubat 1336/1920, Nu: 412 2712; Mustafa Kemal Paşa'nın "İttihatçılık" sayesinde bu günlere geldiğini iddia eden yazılarda kaleme alınmıştır. Bkz. Peyam, Ali Kemal, "Harekât-1 Milliye'nin İç Yüzü”, 14 Teşrin-i Sani (Kasım) 1335/1919, Nu: 344-102; Ali Kemal bir makalesinde de "Yansin o gönül ateșe bu hale ki yanmaz / Kör olsun o gözler ki bu dem kanâ boyanmaz" dedikten sonra Ittthatçıların saltanatı on iki senedir ellerinde bulundurduklarını ve devleti acı olaylardan olaylara sürüklediklerini iddia etmektedir. Bkz. Peyam-ı Sabah, Ali Kemal, "Lanet! Lanet! Lanet!”, 15 Mayıs 1336/1920, Nu: 527-10957. ; Bir diğer makalede de Harekât-1 Milliye bir İttihatçı faaliyeti olarak kabul edilmekte ve İttihatçılık Isırgan Otu ile özdeşleştirilmektedir. Bkz. Alemdar, Refik Halit, "Isırgan Otu”, 2 Nisan 1336/1920, Nu: 471-2771.

Jaeschke, Türk Kurtuluş Savaşı Kronolojisi, s. 64; Sarıhan, Kurtuluş Savaşı Günlü̈̆̈̈̈, Cilt: 2, s. 113. 110.

Eric Jan Zürcher, Millî Mücadele’de İttihatçılık, İletișim Yayınları, İst-2003, s. 109-

${ }^{57}$ Takvim-i Vekâyi, 4 Ağustos 1336/1920, Nu: 3921. 
Milliye'nin bazı lider kadrosu olsun daha önceden İttihat ve Terakki Cemiyeti'nin içerisinde bulunmuşlardı. Fakat sırf buna dayanarak Millî Mücadele'yi bir "Ittthatçı dolabı" olarak nitelendirmek hem mesnetsiz hem de gayr-1 ilmî bir yaklaşım olmaktan öteye gitmeyecektir.

Mustafa Kemal Paşa'nın 27/28 Eylül 1919 gecesi Kerim Paşa ile yaptığ1 telgraf görüşmesinde de "İttihatçıllı" yakıştırması mevzubahis edilmiş ve Paşa, "Asil ve temiz Millî Mücadele'mizin, İttihatçıların son çırpınışları ve kanlı hareketleri olduğunu ve onların parasıly yürütüldüğünü resmen ve açıtan açığa bütün dünyaya ve yabancı gazetecilere söyleyen bu -Damat Ferit, Adil Bey ve Süleyman Şefik kastediliyor- gafillerdir" ${ }^{, 58}$ diyerek İstanbul Hükümeti'ni şiddetli bir şekilde eleştirmiştir. Kaldı ki İstanbul Hükümeti'nin yapmış olduğu "İttihatçıllk" propagandası epey taraftar toplamış olmalı ki Sivas Kongresi'nde yemin edilirken Millî Mücadele'nin İttihat ve Terakki ile kati surette bağlantısı olmadığ 1 ssrarla vurgulanmıştır ${ }^{59}$.

İttihatçılık propagandasının fayda vermemesi üzerine bu kez Kuvâ-yı Milliyeciler Damat Ferit Paşa Hükümetince "Bolşeviklik”le itham edilmeye başlanmıştır $^{60}$. Nitekim yukarıda da belirtilen Mustafa Kemal Paşa ve Kerim Paşa arasındaki telgraf görüşmesinde "Bolşeviklik" mevzuu da

${ }^{58}$ Atatürk, Nutuk, s. 123.

59 "Kongre'nin kabul ettiği yemin formülü şuydu: - Saadet ve selâmeti vatan ve milletten başka hiçbir maksadı şahsî takip etmeyeceğime, İttihat ve Terakki cemiyetinin ihyasına çalışmayacağıma, mevcut fruku siyasiyeden hiçbirinin emeli ve siyasiyesine hâdim olmıyacağıma vallahi billâhi..." Bkz. Kansu, Atatürk'le Beraber, Cilt: 1, s. 219; Ayrıca Mustafa Kemal Paşa'nın İttihat Terakki ile ilişkileri ve "İttihatçı" olmadığı hakkında tafsilat için, Bkz. Fethi Tevetoğlu, "Atatürk-İttihat ve Terakki", Atatürk Araștırma Merkezi Dergisi, Cilt: V, Sayı: 15, Temmuz-1989, s. 612-623; E. Semih Yalçın-Salim Koca, Mustafa Kemal Paşa'nın Anadolu'ya Geçişi, Berikan Yayınevi, Ankara-2005, s. 21-80; Yine millî hareketi İttihatçıların faaliyetlerinden uzak tutma teşebbüsleri hakkında tafsilat için, Bkz. Emine Kısıkl1, "Millî Mücadele Başlangıcında, Mustafa Kemal Paşa'nın Millî Hareketi, İttihat ve Terakki Faaliyetlerinde Uzak Tutma Teşebbüsleri”, Ankara Üniversitesi Türk İnkılâp Tarihi Enstitüsü̈ Atatürk Yolu Dergisi, Y11: 3, Say1: 5, Ankara-1990, s. 109-127.

604 Ağustos 1920 tarihli Takvim-i Vekâyi'de yayınlanan beyanname de Bolşeviklik mevzuunda șu bilgilere rastlanmaktadır: "...Bolșeviklerden istimdad ediyorlar. Millet- $i$ Osmaniye'ye bundan büyük hürmetsizlik olamaz. Mahza hasâil bir güzîde ve fazâil-i ahlakiyesiyle dünyanın en büyük bir devletini tesîs ve asırlarca idâme etmiş olan afîf ve edîb ve hulûk-ı necîb ve seriat-ı garra-yı muhammediveye hürmetkâr Türk kavmi, inkâr-ı hâk ve hakîkat, iştirak-ı emvâl ve zevcât, katl- nüfûs ve gasb-l emvâl esasina istinâd eden ve insaniyetten ziyâde behîmiyyete mütekarib bulunan bir meslek-i dalâlden ve Bolșevikler gibi Allah'in ve insanların düsmanlarından istimdâd etmez, bi'l-nisbe asgarî beladan azamî belaya ilticâ etmek gibi gafilâne ve mecnunâne bir harekete rıza göstermez". Bkz. Takvim-i Vekâyi, 4 Ağustos 1336/1920, Nu: 3921.

“Kuvâ-yı Milliyecilerin Bolşevik oldukları, Hükümeti Allah'ı ve mabudu tanımadıkları şeklinde propagandalar yapılmasl. Propagandaya inanan bassta Adapazarı halkı olmak üzere birçok insan baltasını kaparak "nerede bulasıklar" naralarıyla Kuvâ-yı Milliyeci avına çıkmışlardır.”, Bkz. Mehmet Temel, İsgal Yıllarında İstanbul'un Sosyal Durumu, Kültür Bakanlığı Yayınları, Ankara-1998, s. 105. 
değerlendirilmiş ve Mustafa Kemal Paşa bu hususta, "Memleketimize takım takım Bolşeviklerin girdiğini ve Millî Mücadele’nin bir Bolşevik mücadelesi olduğunu resmî olarak ilan eden ve yayan -yine burada da Damat Ferit, Adil Bey ve Süleyman Şefik kastedilmektedir- bu bahtsızlardır" ${ }^{61}$ demiştir.

Dönemin matbuatını incelediğimizde "Bolşeviklik" mevzuunun, Millî Mücadele'ye muhalif basın tarafindan, halkı bu mücadeleye karşı soğutmak maksadıyla ustaca kullanıldı̆̆ını görmekteyiz. Mesela Alemdar Gazetesi Başmuharriri Refii Cevad bir makalesinde, “...Itttihat ve Terakki'nin tarz-l idaresi memleketi mahvetmekle neticelenmiştir. Memleket bu hale geldikten sonra artık o felaketli idareye idare demek için mecnun olmall. Ittihatçllık bahusus İttihatçıllğın Anadolu'daki şimdiki şekli Bolşevikliğin kıpkızll bir şeklidir" ${ }^{62}$ demekte ve "Anadolu Hareketi"ni bu suretle en ağır şekilde itham etmiş olmaktadır.

Damat Ferit Paşa Hükümetlerinin Kuvâ-y1 Milliye'ye yönelik ithamlarından bir diğeri de onların milliyetçiliklerinin sahte olduğu üzerinedir $^{63}$. Yine gerek devletin resmî yazışmalarında olsun gerekse de matbuatta olsun Kuvâ-yı Milliye Hareketi; Kuvâ-yı Gayr-1 Milliye, Kuvâ-y1 Bağiye, sergerde, şekavet ehli, kemali çeteleri, dinsiz, fitne-i bağiye ve Anadolu'nun yeni Celâlîleri gibi ithamlara maruz kalmıştır ${ }^{64}$.

Damat Ferit Paşa üçüncü Sadaret'inde pek çok Kuvâ-yı Milliye taraftarını azletmiştir. Örneğin Ali Fuat Paşa 28 Ağustos 1919 tarihinde 20. Kolordu Kumandanlığı'ndan azledilmiştir ${ }^{65}$. Ayrıca Ödemiş Kaymakamı Bekir Sami Bey de 8 Temmuz'da görevinden azledilmiştir ${ }^{66}$.

Damat Ferit Paşa, konumuzun özünü teşkil eden IV. Sadareti döneminde Kuvâ-yı Milliye Hareketi’ne yönelik faaliyetlerini daha da katı

${ }_{62}^{61}$ Atatürk, Nutuk, s. 123.

2 Alemdar, Refii Cevad, "Bolșevik Av1”, 29 Eylül 1335/1919, Nu: 187-1587; Bir diğer Bolşeviklik suçlaması için Bkz. Alemdar, Aydede (Refik Halit), "Nakş-1 Ber Âb -Lenin Yerine Grinin-“, 3 Kanun-1 Sani (Ocak) 1336/1920, Nu: 383-2683.

3 Alemdar, Doktor Selahattin Ali, "Nasıl Millileşmeli ve Milliyetperverlik Nedir?", 1 Şubat 1336/1920, Nu: 411-2711; Peyam-ı Sabah, Ali Kemal, "Sergerdelerin Milliyetleri”, 13 Nisan 1336/1920, Nu: 495-10925; Takvim-i Vekâyi, 11 Nisan 1336/1920, Nu: 3824.

${ }^{64}$ Birçok resmî yazıșmada Anadolu Hareketi "Kuvâ-yı Milliye namı altında çıkarılan fitne ve fesad" olarak nitelendirilmektedir. Mesela Bkz. BOA, BEO, Umumi No: 347778. Matbuatta da Kuvâ-yı Milliye aleyhine kaleme alınmış birçok yazı bulmak mümkün. Bunlardan birkaç1: Alemdar, 20 Nisan 1336/1920, Nu: 488-2788; Alemdar, Refii Cevad, "Kuvâ-y1 Gayr-1 Milliye Suya Düştükten Sonra”, 2 Mayıs 1336/1920, Nu: 496-2806; Peyam, Ali Kemal, "Kimi Aldatiyorlar", 28 Eylül 1335/1919, Nu: 297-55; Peyam, Ali Kemal, "Gayr1 Meşru Kuvvetler", 21 Teşrin-i Sani (Kasım) 1335/1919, Nu: 351-109; Alemdar, Refii Cevad, “Turancilar ve Türkler Amma Hakiki Türkler”, 20 Eylül 1335/1919, Nu: 178-1578. Cilt: 1, s. 392 Takvim-i Vekâyi, 31 Ağustos 1335/1919, Nu: 3637; Karabekir, İstiklal Harbimiz,

${ }^{66}$ Takvim-i Vekâyi, 14 Temmuz 1335/1919, Nu: 3597. 
bir şekilde uygulamaya koymuştur. Nitekim, Saray'ın ve İngilizlerin tam desteğini alan Damat Ferit Paşa, plan ve programının gereği olan faaliyet ve uygulamalarına vakit kaybetmeden başladı. İlk olarak Anzavur Ahmet'e paşalık unvanını verdi ve onu tekrar Balıkesir mutasarrıflığına atadı ${ }^{67} .10$ Nisan'da ise Bursa eski valisi olan Nemrut Mustafa Paşa' ${ }_{1}{ }^{68}$, tehcir ve taktil davalarının görüldüğü İstanbul'daki Divan-1 Harb-i Örfi Başkanlığı'na getirildi ${ }^{69}$.

Damat Ferit Paşa'nın Kuvâ-yı Milliye'ye karş1 uygulamaya koyduğu plan ve programın esas1 olan karar ve uygulamalar 11 Nisan tarihli Takvim-i Vekâyi'de yayınlandı.

Takvim-i Vekâyi'de yayınlanan kararların ilki Meclis-i Mebusan'ın kapatılması ile ilgili iradeydi; 11 Nisan tarihli bu irade ile Padişah, Anayasa'nın 7 maddesinin kendisine verdiği bir hak olarak dört ay zarfında yeniden toplanmak üzere "Meclis- $i$ Mebusan' $\imath$ " kapatmıştı". Böylece Padişah ve Damat Ferit Paşa, Kuvâ-yı Milliye hareketine yönelik karar ve uygulamalarında kendileri için bir engel olarak gördükleri Meclis’ten

${ }^{67}$ Alemdar, 9 Nisan 1336/1920, Nu: 473-2784; Peyam-ı Sabah, 9 Nisan 1336/1920, Nu: 491/10921; Anzavur Ahmet ile ilgili Alemdar ve Peyam-1 Sabah'ta s1k s1k övücü tarzda yazılar çıkmaktaydı. 7 Nisan da Alemdar'da çıkan bir haberde "Biga-Gönen ve havalisini gayr-i milli çetelerden temizleyen binbaşı olarak şimdiye karş̧ gösterdiği kahramanlıkları șimdide gösterecektir" deniliyordu. Bkz. Alemdar, 7 Nisan 1336/1920, Nu: 471/2782; 8 Nisan tarihli Alemdar'da ise "Ahmet Anzavur Bey'in yeni bir muvaffakiyeti" başlığı altında onun Gönen kazasını Kuvâ-yı Milliyecilerden kurtardığı haberi yer alıyordu. Alemdar, 8 Nisan 1336/1920, Nu: 472-2783; Anzavur Ahmet, Haziran 1919'da İzmit mutasarrıflığından Balıkesir mutasarrıflığına atanmış, ancak görevine başlayamamıştı. Anzavur Ahmet, Kuvâ-yı Milliye'ye karşı yürütülen hareketlerin başını çekiyordu. Bkz. Erdem, Damat Ferit Paşa, s. $158-159$.

68 Damat Ferit Paşa'nın üçüncü sadaretinde Bursa valiliği görevine atanan Nemrut Mustafa Paşa, valilik görevine başladığ 1 ilk günlerde vilayette yaptığı bir toplantıda "Ermeni, Rum ve Müslüman halkın yanında yapılmakta olan savașların meșru olmadığını, keza birinci dünya harbinin de öyle olduğunu, dolaylsiyla bu harplerde ölen subay ve erlerin köpek ölüsünden farklı bir durumlarının" olmadığını söyleyerek sehit asker ve subaylarımıza hakarette bulunmuştu. Bu sözler Bursa ve civarındaki askeri birliklerdeki subay ve askerler arasında büyük bir infial yaratmıştı. Bunun üzerine $56 \mathrm{nc1}$ Tümen Komutanı Miralay Bekir Sami Bey tarafindan derhal Bursa'yı terk etmesi istenmiști. Böylece Nemrut Mustafa Paşa, valilikten uzaklaştırılarak Bursa'yı terk ederek İstanbul'a dönmüştü. Daha geniş bilgi için bkz. Miralay Bekir Sami Günsav'ın Kurtuluş Savaşı Antları, Hazırlayan: Muhittin Ünal, Cem Yayınları, II. Basım, İstanbul-2002, s. 163-166.

${ }^{69}$ Takvim-i Vekâyi, 10 Nisan 1336/1920, No: 3829

${ }^{70} \boldsymbol{B O A}, \boldsymbol{B E O}$, Nu: 347035, Ayrica bu İrade-i Seniyye için bkz. Takvim-i Vekâyi, 11 Nisan 1336/1920, Nu: 3824; Meclis-i Mebusan'ın kapatılmasıyla ilgili İrade-i Seniyye, 13 Nisan tarihli Alemdar gazetesinde de yayınlanmıştı. Bkz. Alemdar, 13 Nisan 1336/1920, Nu: 477-2787; Ali Rıza Paşa ve Salih Paşa Hükümetlerinde nazır olarak görev yapan Mehmet Tevfik Bey, zaten Mebusan Meclisi müzakerelerini süresiz olarak tatil ettiği için, dağılmıştı. Mebusan Meclisin fesih edilmesi sembolik bir anlam ifade ediyordu ve aynı zamanda da usulsüz bir işlemdi demektedir. Bkz. Mehmet Tevfik Bey'in (Biren) Abdülhamit, Meșrutiyet ve Mütareke Devri Hatıraları, Yayına Hazırlayan: F. Rezan Hürmen, Cilt II, Arma Yayınları, İstanbul-1993, s. 393. 
kurtulmaya ve Ankara'da toplanacağı açıklanan Meclisin açılmasını önlemeye çalışmışlard ${ }^{71}$. Alemdar gazetesi Meclis-i Mebusan'ın kapatılması kararını adeta destekler mahiyette "Mebusan Lâyık Olduğu Akibete Uğradı" başlığ ile duyurmuştu ${ }^{72}$.

11 Nisan tarihli Takvim-i Vekâyi'de Damat Ferit Paşa Hükümeti’nin bir beyannamesi de yayınlanmıştı" ${ }^{73}$. Bu beyanname "Hükümetin Pek Mühim ve Tarihi Bir Beyânnamesi" ifadesiyle gazetelerde yer almışt ${ }^{74}$. Bu beyannamede "Bir takım fitne-fesat, hırs ve menfaat düşkünü insanlar Teşkilât-ı Milliye adı altında toplanarak, ülkenin siyasi durumunu çok tehlikeli bir duruma soktukları. Bunları harp yıllarında yaptıkları suiistimal ve cinayetlerine mütarekeden sonra da devam ettikleri ve böylece Avrupa kamuoyunu aleyhimize çevirdikleri, bunun sonucunda da İstanbul'un işgal edildiğinden" bahsediliyordu. Beyannamede devamla "Teşkilât-ı Milliye denilen harekât-ı bagiyânenin Anadolu'yu korkunç bir istilaya sokmaya ve devletin başını gövdesinden ayırmaya çalıştıkları" belirtilerek, yalancı milliyet davası güdenlerin devletin en büyük düşmanları olduğu ilan ediliyordu.

Beyannamede Teşkilâtı Milliye, eşkıyalık ve isyan hareketi olarak suçlanıyordu. Bunların kanunlara karşı geldikleri, halktan zorla para ve asker topladıkları, vermeyenleri ise cezalandırdıkları zikredilerek, bir hafta zarfında bu teşkilata katılanlardan pişmanlık duyacakların Padişah tarafından affedilecekleri, diğerlerinin ise şiddetle cezalandırılacakları belirtiliyordu.

Damat Ferit Paşa yayınladığı bu beyanname ile Kuvâ-yı Milliye aleyhine kamuoyu oluşturarak, girişeceği mücadelede halkın desteğini sağlamayı amaçlıyordu.

Damat Ferit Paşa Hükümeti'nin bu beyannamesinin yanında, 11 Nisan tarihli Takvim-i Vekâyi'de bir de Şeyhülislâm Dürrizade Abdullah Efendi tarafindan, "başta Mustafa Kemal Paşa ve arkadaşları olmak üzere, Kuvâ-yı Milliye hareketi liderlerinin vatan haini olduklarl ve öldürülmelerinin dinen

71 Esasında Meclis-i Mebusan, 18 Mart 1920'de son toplantısını yapmıș ve çalışmalarına ara verme kararı almıştı. Meclis-i Mebusan'ın çalışmalarına ara vermesi ve kapatılmasıyla ilgili gelişmeler için, Bkz. Bilâl N. Şimşir, Malta Sürgünleri, İstanbul-1976, s. 20-21; 124-128; Ahmet Emin Yalman, Yakın Tarihte Gördüklerim ve Geçirdiklerim I, Yayına Hazırlayan: Erol Sadi Erdinç, İstanbul-1997, s. 676-677; Hilmi Uran, Hatıralarım, Ankara-1959, s. 126-130.

Alemdar, 13 Nisan 1336/1920, Nu: 477-2787; Vakit, 13 Nisan 1336/1920, Nu: 873. $480-2780$

Takvim-i Vekâyi, 11 Nisan 1336/1920, Nu: 3824; Alemdar, 11 Nisan 1336/1920, Nu: 480-2780.

Takvim-i Vekâyi, 11 Nisan 1336/1920, Nu: 3824; Alemdar, 11 Nisan 1336/1920, Nu: 
meşru ve farz olduğunu beyan eden" fetva da yayınlanmışt1 ${ }^{75}$. Fetva, Takvim-i Vekâyi dışında İstanbul'da yayınlanan birçok gazetede de yer almışt1 ${ }^{76}$. Nitekim Peyam-1 Sabah'ta Ali Kemal fetvayı savunan bir yazı yazarak "yalancı milliyet davası şer'i şerife aykırıdır" diyecek ${ }^{77}$, Alemdar'da çıkan yazılarda da fetva savunularak "Mustafa Kemal müstahak olduğu cezayı" buldu denilecektir ${ }^{78}$.

Şeyhülislâm Dürrizade Abdullah Efendi imzalı bu fetvada, Kuvâ-yı Milliye hareketi mensuplar1; "Íslâm Halîfesi'nin idaresi altında yaşayan ve Padişah'a bağlı olan halkı hîle ve yalanlarla kandırmak, asker toplamak, vergi koymak ve zorla halkın malını ve mülkünü almakla" suçlanmaktaydılar. Fetvada; bunların halifeye isyan ve ihanet ederek memleketin asayişini bozdukları ve bunlarla birlikte hareket edenlerin bagi oldukları belirtiliyordu. Bu Fetva'da özetle; Kuvâ-yı Milliye hareketi, eşkıya kuvvetleri olarak nitelendirilmekte, Anadolu ile İstanbul arasındaki bağları koparmak, halifenin yüceliğini zedelemek, padişaha itaatsizlik etmek, mevcut düzeni zorla değiştirmeye kalkışmak, halktan zorla mal ve eşya toplamak, halkı zorla kendine asker etmek ve nihayet vatanın birlik ve bütünlügünü bozmakla suçlanmakta ve hüküm olarak da bu asilerin öldürülmelerinin dinen farz olduğu vurgulanmaktayd ${ }^{79}$. Şüphesiz bu fetva

${ }^{75}$ Takvim-i Vekâyi, 11 Nisan 1336/1920, Nu: 3824; Alemdar, 11 Nisan 1336/1920, Nu: 480-2780; Damat Ferit Paşa Hükümetinde Dahiliye Nazırı olarak görev yapan Ahmet Reșid Bey hatıralarında, fetvanın ilan edilmeden önce hükümet üyeleri arasında uzun uzadıya tartıșıldığı ve yaratacağı sakıncalar üzerinde durulduğundan bahsetmekte ve devamla İngilizlerin fetva konusunda 1srar ettiklerini söyleyen Damat Ferit Paşa'nın, bu fetvanın ilan edileceğine dair İngilizlere söz vermiş olduğunu bu toplantıda Hükümet üyelerine açıkladığını belirtmektedir. Bkz. Ahmet Resit Rey, Canlı Tarihler, Gördüklerim Yaptıklarım, Istanbul 1945, s. 284; Fetvanın İngilizlerin 1srarı karşısında ilan edildiği şeklindeki Damat Ferit Paşa'nın iddiasını inandırıcı bulmayan Jaeschke "Foreign Office dosyalarında bu iddiayı destekleyebilecek hiçbir șey yoktur" demekte ve "fetva'nın ecnebi ısrarl ile değil garaz ve hamakat eseri olduğu malûm" diyen Ahmet Reşid Bey'i haklı bulduğunu belirtmektedir. Bkz. Gotthard Jaeschke, Kurtuluş Savaşı İle İlgili İngiliz Belgeleri, Türkçeye Çeviren: Cemal Köprülü, Türk Tarih Kurumu Basımevi, Ankara-1971, s. 153.

${ }^{76}$ Takvim-i Vekâyi, 11 Nisan 1336/1920, Nu: 3824; Alemdar, 11 Nisan 1336/1920, Nu: 480-2780; Peyam-ı Sabah, 11 Nisan 1336/1920, Nu: 493/10923; Bu fetvanın metni için bkz. İnal, Son Sadrazamlar, s. 254-255; Bıyıkoğlu, Trakya'da Millî Mücadele, Cilt: II, s.82-83; HTVD, Sayı: 35, Belge No: 875; Galip Kemali Söylemezoğlu, Başımıza Gelenler (Yakın Bir Mazinin Haturalart), Kanaat Kitabevi, İstanbul-1939, s. 216-218; Nureddin Peker, 1918-1923 İstiklâl Savașı'nın Vesika ve Resimleri (İnebolu-Kastamonu ve Havalisi Deniz ve Kara Harekâtı), İstanbul-1955, s. 166-167; Ebubekir, Hazım Tepeyran, Belgelerle Kurtuluş Savaşı Anıları, Cağdas Yayınları, İstanbul-1982, s. 148-150.

Áli Kemal'in "SSeriat, Padişah, Adalet" başlıklı yazısı için, Bkz. Peyam-ı Sabah, 11 Nisan 1336/1920, Nu: 493/10923.

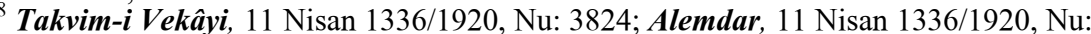
$480-2780$.

9 Dürrîzâde Abdullah Efendi'nin fetvası hakkında tafsilat icin, Bkz. Osman Akandere, "11 Nisan 1920 (1336) Tarihli Takvim-i Vekâyi'de Kuvâ-yı Milliye Aleyhinde Yayınlanan Kararlar”, Ankara Üniversitesi Türk İnkılâp Tarihi Enstitüsü Atatürk Yolu Dergisi, Y11: 12, 
ile halkın dinî hassasiyetinden faydalanılmaya çalışılmakta ve "Anadolu Hareketi"ne karşı taarruza geçmenin dinî bir gereklilik olduğu Müslümanların dikkatlerine sunulmaktadır.

Yine söz konusu Fetva da, Kuvâ-y1 Milliyecilerin kötülüklerinden memleketi temizlemenin ve halkı kurtarmanın vacip kılındığı, bu gibileri öldürmenin de meşru ve farz olduğunu zikrediliyordu. Bunlarla mücadele etmek amaciyla "Halife tarafindan görevlendirilen ve gönderilen askerlerin, görevlerini yapmamaları halinde Allah katında büyük günah işlemiş olacakları" da fetvanın son kısımlarında belirtiliyordu.

Görüleceği gibi Damat Ferit Paşa, Kuvâ-yı Milliye hareketine karşı giriştiği amansız mücadelede, bu fetva ile Anadolu'daki Müslüman halkın en zayıf noktasına yönelerek, onların saf ve masum dinî duygularını istismar ediyordu.

Bütün bunların yanında Padişah Vahdettin'in Damat Ferit Paşa'yı, dördüncü defa iktidara getirdiği ve muhtevasında Kuvâ-yı Milliye aleyhinde hükümlerin yer aldığı "Hatt-ı Hümayun" da 11 Nisan tarihli Takvim-i Vekâyi'de bir kez daha yayınlanmıştı ${ }^{80}$.

Şeyhülislâm Dürrizade tarafından çıkartılan fetvalar, Anadolu'nun birçok bölgesine İngiliz uçaklarıyla atılarak ${ }^{81}$, halkın bu fetvalardan haberdar olması ve Kuvâ-yı Milliye'ye karşı kamuoyu oluşturularak harekete geçmesi sağlanmaya çalışılmıştır.

Hükümetin yayınladığı beyanname ve özellikle şeyhülislâm Dürrizade'nin çıkarmış olduğu ve başta İngiliz uçakları olmak üzere her türlü vasıta ve yollarla ülkenin içlerine sokulmaya çalışılan fetvalar, Anadolu'da Kuvâ-yı Milliye hareketine karşı büyük bir olumsuz hava yaratmıştı. Özellikle bu beyanname ile fetvaların Anadolu'da yayılmasının hemen akabinde birçok bölgede Kuvâ-yı Milliye'ye karşı ayaklanmalar çıkmıştı Millî Mücadele'ye karşı çıkan bu isyanlardan Haçin, Pontus, Ali Batı ve Koçgiri dışındaki diğer isyanların hepsinde din, hilâfet ve Padişah birer propaganda aracı olarak kullanılmış, halkı kandırmak için istismar edilmiştir $^{82}$. Bilhassa Bolu, Düzce ve Hendek bölgesindeki isyan hareketleri

Sayı: 24, Ankara-2003, s. 441-450; Hülya Özkan, İstanbul Hükümetleri Karşıtı Faaliyetleri (4 Mart 1919-16 Ekim 1920), Genelkurmay Basımevi, Ankara-1994, s. 89-92.

${ }_{81}^{80}$ Takvim-i Vekâyi, 11 Nisan 1336/1920, Nu: 3824.

81 Alemdar, 23 Nisan 1336/1920, Nu: 487-2881; Jaeschke, Türk Kurtuluş Savaşı Kronolojisi, s. 99 .

${ }^{82} \mathrm{Bu}$ değerlendirme için, Bkz. Kenan Esengin, Millî Mücadele’de Ayaklanmalar, III. Basım, Kamer Yayınları, İstanbul-1998, s. 30. 
ile Konya İsyanı'nda Hükümetin beyannamesi ile şeyhülislamın fetvaları oldukça etkili olmuştur ${ }^{83}$.

$\mathrm{Bu}$ beyanname ve fetvalardan azami ölçüde istifade edenlerden birisi de Anzavur Ahmet Paşadır ${ }^{84}$. Damat Ferit Paşa Hükümeti ve İngilizler tarafından Kuvâ-yı Milliye hareketini yok etmek için silahlandırılan Anzavur Ahmet, halife ve din adına hareket ettiğini ${ }^{85}$ her firsatta halka göstermeye, onları etkilemeye ve iğfal etmeye çalışmıştır. Nitekim emrindeki kuvvetleri "Kuvâ-yı Muhammediye" diye adlandırmış, amacının Hilâfeti korumak olduğunu ve Halife adına hareket ettiğini gittiği her yerde söyleyerek, Kuvây1 Milliye'nin ülkeyi bölmeye yönelik bir hareket olduğu, bunların din, devlet ve Padişah düşmanı olduklarını ${ }^{86}$, kendisinin Kuvâ-yı Milliye hareketini yok etmeye yemin ettiğini anlatmaya çalışmıştır ${ }^{87}$.

Yayınlanan beyanname ve fetvalarla Anadolu halkının zihinlerini bulandıran ve birçok yerde Kuvâ-yı Milliye hareketine karşı isyanların çıkmasını sağlayan Damat Ferit Paşa, Padişahın ve Hükümetin Anadolu'da yeniden otorite sağlamak ve hâkimiyetini tesis etmek amacıyla bir takım tertiplere daha girişmişti. Bunun içinde öncelikli olarak Kuvâ-yı Milliye'ye karşı mücadele edecek askeri birlikler oluşturmaya karar vermişti ${ }^{88}$. Aslında

${ }^{83}$ Hükümet beyannamesi ile Seyhülislâm Dürrizade'nin fetvalarının çıkan isyanlarda etkili olduğuna ilişkin olarak Konya'da çıkan "Konya İsyanı iyi bir örnek olarak gösterilebilir. Bu isyanla ilgili bir raporda "hadiseden 25 gün önce Konya'nın Kumköprü bağında Cambabzade Mevlüt'ün bağ evindeki 20 kișilik bir çay ziyafetinde İstanbul'un neşrettiği fetva ve Padişahın beyannamesi bahis konusu olmuş, Halkı Kuvâyı Milliye aleyhine toplamak kararı alınmıștır. Beyanname ve fetvayı(...) köylere gönderilecekler ayrılmıs, bunlara fetva ve beyanname bulunan Istanbul gazeteleri verilmiștir...", Bkz. İmparatorluktan Cumhuriyete (Fahrettin Altay Paşa Anlattyor), Yayına Hazırlayan: Taylan Sorgun, II. Basım, Kamer Yayınları, İstanbul 1998, s. 243.

Damat Ferit Paşa Hükümeti tarafindan 8 Nisan 1920'de Anzavur Ahmet'e mir-i miranlık (paşalık) rütbesi verilerek Karesi (Balıkesir) Mutasarrıflığına tayin edilmiştir. Alemdar, 8 Nisan 1336/1920, Nu: 472-2783; Peyam-ı Sabah, 9 Nisan 1336/1920, Nu: 491/1092; Anzavur Ahmet'e paşalık rütbesi verilerek Balıkesir mutasarrıflığına tayini 13 Nisan 1336/1920 tarihli Hakimiyet-i Milliye'de haber olarak verilmiştir. Bkz. Hakimiyet-i Milliye, 13 Nisan 1336/1920, Nu: 21.

Ahmet Anzavur'un, Kuvâ-yı Milliye'ye karşı “din uğruna, Kur'ana dayanarak" mücadele yaptığını, kendisinin ve arkadaşlarının "Allah yolunda cihad ettikleri" gibi halkı etkilemeye yönelik söylemler, mütemadiyen Kuvâ-yı Milliye aleyhtarı gazetelerde yayınlaniyordu. Bkz. Alemdar, 10 Nisan 1336/1920, Nu: 474/2785; Alemdar, 15 Nisan 1336/1920, Nu: 479/2789

${ }_{87}$ Alemdar, 25 May1s 1336/1920, Nu: 519/2829.

${ }_{87}$ Anzavur Ahmet, gazete muhabirlerine verdiği bir demeçte "Anadolu halkının İttihatçıların bakiyesi Mustafa Kemal çetesi ve yardakçılarının zulüm gördüğ̈̈nü bu nedenle padişahın, Hükümetin ve vatanın uğruna hayatını vakfettiğini, hayatının sonuna kadar uğrașarak, Mustafa Kemal ve avanesini tepeleyeceğini" söylemişti. Bkz. Alemdar, 26 Nisan 1336/1920, Nu: 490-2800

88 Hüsamettin Ertürk, Kuvâ-y1 İnzibatiye'nin kurulması konusunda “....Sadâret'le beraber bizzat Damat Ferit Pasa deruhte etmisti. Ferit Pașa'nın bütün arzusu, Anadolu'da taazzuva başlayan Millî Hükümet'i ylkmak, Mustafa Kemal'i dize getirmekti. Bunun da kuvvetle olacağına inanmış, Hilâfet ordusu nâmıla bir ordu tesisine ve adına Kuvâ-yı 
kendisinin kontrolünde kurulacak düzenli bir askerî birlik için, 11 Nisan'da İngiliz Yüksek Komiseri Amiral de Robeck'le yaptığı görüşmede, ondan destek sözü de almıști ${ }^{89}$.

Kuvâ-yı Milliye hareketini, Türk'ü Türk'e kırdırarak bastırmak ve parçalamak demek olan bu planı, İngilizlerin yanında ${ }^{90}$; İngiliz Muhibleri Cemiyeti ${ }^{91}$, Hürriyet ve İtilâf Fırkası ile Askeri Nigehban ve Kızılhançerliler gibi cemiyetler de desteklemişler ve para yardımı yapmışlardır ${ }^{92}$. Kuvâ-yı İnzibatiye adiyla bir ordunun kurulmasıla ilgili kararname 18 Nisan'da Hükümet tarafından çıkarıldı ${ }^{93}$. Bu kararname ile jandarma kuvvetlerine benzer ve gönüllülerden oluşan Kuvâ-yı İnzibatiye'nin kurulması kararlaştırıld1. Kararnamede "devlet yasalarını uygulayan Hükümet memurlarını zor kullanarak görevini yapmaya engel olan ve Kuvâ-yı Milliye adını taşıyan eşkiyaları tepelemek için Kuvâ-yı Inzibatiye kurulmuştur. Kuvâ-yl İnzibatiye devletin silahl kuvvetidir. Bu kuruluş Harbiye ve Dâhiliye Nezaretine bağlı olacaktır. Aynı zamanda kolluk kuvvetlerine de yardım edecektir" deniliyordu. Bu kuvvetin subayları halen görevli olanlarla emekli ve gönüllülerden oluşacaktı1 ${ }^{94}$. Kuvâ-yı İnzibatiye Kararnamesi’nin

Inzibatiye denilmesine karar vermiş ve bu husustaki muktazi iradeyi de Sultan Vahideddin'den istihsal eylemişti" demektedir. Bkz. Samih Nafiz Tansu, Iki Devrin Perde Arkası, Anlatan: Hüsamettin Ertürk, Sebil Yayınları, İstanbul-1996, s. 377-378.

Amiral de Robeck'in İngiliz Dışişleri Bakanı Lord Curzon'a bu görüşmeyle ilgili gönderdiği raporda “Damat Ferit Pașa 'nın Anadolu'daki millî harekâtın bastırılabilmesi için, kuvvetle karssı konulması gerektiğini, bu konuda Itilaf Devletleri'nin kendisine ne ölçüde yardım edebileceklerini sorması üzerine kendisinin de İngiliz Yüksek Komiserliginin millivetçilere karşı kuvvetlerin silahlandırlmalarına müsaade edileceği ve baskaca yardımların sonradan geleceğini, milliyetçileri bastırması için İtilaf devletlerinin Hükümeti tamamen destekleyeceklerini" söylediğini belirtmektedir. Şimşir, Ingiliz Belgelerinde Atatürk, Cilt: II, s. 29.

İngilizleri denetimlerindeki Türk silah depolarından Kuvâ-yı İnzibatiye'ye silah dağıtılmasına izin vermişlerdi. Bkz. Salahi R. Sonyel, Kurtuluş Savaşı Günlerinde İngiliz İstihbarat Servisi'nin Türkiye'deki Eylemleri, Türk Tarih Kurumu Basımevi, Ankara 1995, s. 70.

91 İngiliz Muhipler Cemiyeti, Anzavur İsyanı ile Kuvâ-yı İnzibatiye ve Kuvâ-yı Muhammediye hareketleri gibi kardeşi kardeşe kırdıran menfî hadiselerin hazırlanmasında büyük rol oynamıştır. Bu değerlendirme için, Bkz. Cengiz Dönmez, Millî Mücadele’ye Karşı Bir Cemiyet, İngiliz Muhibleri Cemiyeti, Atatürk Araştırma Merkezi Yayınları, Ankara-1999, s. 150 .

92 Günay Çağlar, "Kuvây-1 İnzibâtiye”, Ankara Üniversitesi Türk İnkılâp Tarihi Enstitüsü Atatürk Yolu Dergisi, Sayı: 4, 15 Mayıs 1995, s. 344.

9318 maddelik Kuvâ-yı İnzibatiye kararnamesi aynı gün Takvim-i Vekâyi'de de yayınlanmıştı. Bkz. Takvim-i Vekâyi, 24 Nisan 1336/1920, Nu: 3835. Ayrıca Bkz. Peyam-ı Sabah, 18 Nisan 1336/1920, Nu: 500/10930; Alemdar, 18 Nisan 1336/1920, Nu: 482/2792; Kuvâ-y1 İnzibatiye Kararnamesi'nin tam metni için, Bkz. Sofuoğlu, Kuzeybatı Anadolu, s. (ekler kismi).

${ }_{94}$ Kuvâ-y1 İnzibatiye, subayları ile birlikte 250 mevcutlu bölüklerden kurulacak ve dört bölük bir tabur, dört tabur bir alay olacaktı. Bu kuvvette görev alan askerlere 30 lira, subaylara ise 60 liradan başlamak üzere 150 liraya kadar maas ödenecekti. Bkz. Türk İstiklâl Harbi, Istiklâl Harbinde Ayaklanmalar, Cilt: IV, Genel Kurmay Harp Tarihi Başkanlığı Yayınları, Ankara-1974, s. 119; Peyam-ı Sabah, 23 Nisan 1336/1920, Nu: 505-10935. 
çıkartıldığı 18 Nisan'da, çıkartılan diğer bir kararname ile de Kuvâ-yı İnzibatiye'nin emrine "tahsisat-l fevkalade" olarak 1.250830 lira para tahsis edilmişti ${ }^{95}$. Diğer taraftan 29 Nisan'da Kuvâ-yı İnzibatiye Kumandanlığı'na Ordu Kumandanı yetkisiyle, Süleyman Şefik Paşa getirildi ve kendisine ayrıca "İzmit ve Havâlisi fevkâlade Kumandanlı̆̆ı" unvanı da verildi". Bilahare de kendisinin vazife ve salahiyetine dair bir talimatname düzenlendi ${ }^{97}$. Fakat İzmit'teki görüşmede Anzavur Ahmet'in kendisine emrindeki bir asker gibi davranması Paşa'yı üzdü ve duruma tepkisini dile getirerek kimin komutan olduğunu Damat Ferit Paşa'dan sordu, lakin cevap alamadı. Bunun üzerine görevini bırakarak İzmit'ten ayrıld1 ${ }^{98}$. Paşa'dan boşalan Kuvâ-yı İnzibatiye Kumandanlığına Yarbay Senâi Bey tayin edildi ${ }^{99}$.

Kuvâ-yı İnzibatiye'nin asker ihtiyacını karşılamak için Sadrazam ve Hariciye Nazırı ve Harbiye Nazırı Vekili Damat Ferit Paşa ${ }^{100} 23$ Nisan'da bir beyanname yayınlayarak "İstanbul'da görevde ve açıta bulunan bütün subayların Harbiye Nezâretine gelerek, yoklama yaptırmalart, gelmeyenlerin askerlikle ilgili her türlü ilişkilerinin kesileceği ve seferberlikten kaçmış sayılarak Divan-ı Harbe" verileceklerini duyurdu ${ }^{101}$.

Kuvâ-yı İnzibatiye birliklerine, İstanbul'daki depolardan silah, cephane ve araç-gereç sağlandı ve 966 er ve 66 subaydan oluşan ilk Kuvâ-yı İnzibatiye alay1 29 Nisan'da İzmit'e gönderildi ${ }^{102}$.

95 Takvim-i Vekâyi, 24 Nisan 1336/1920, Nu: 3835; Vakit gazetesinde çıkan bir haberde "Kuvâ-yı Inzibatiye kararnamesi dün Takvim-i Vekâyi'de yayınlanmıștır denilerek, çıkartılan diğer bir kararname ile de Kuvâ-yı İnzibatiye için 1.250. 836 lira ödenek tahsis edildiği" belirtilmektedir. Vakit, 25 Nisan 1336/1920, Nu: 883. Ayrıca kararnamenin maddeleri için, Bkz. Sofuoğlu, Kuzeybatı Anadolu, s. 343, 439 no'lu dipnot.

${ }^{96}$ Takvim-i Vekâyi, 29 Nisan 1336/1920, Nu: 3842; Alemdar, 29 Nisan 1336/1920, Nu: 493-2803; Peyam-ı Sabah, 29 Nisan 1336/1920, Nu: 511/10941.

7 Kuvâ-y1 İnzibatiye Kumandanı Süleyman Sefik Paşa'nın vazife ve salahiyetini belirleyen talimatname için, Bkz. HTVD, Sayı: 51, Belge No: 1174.

Türk İstiklal Harbi -íç Ayaklanmalar (1919-1921)-, Cilt: VI, Genelkurmay Basımevi, Ankara-1964, s. 69.

${ }^{99}$ TiH, Cilt: VI, s. 73.

100 Damat Ferit Paşa, Sadrazam ve Hariciye Nazırlığ görevlerinin yanında 20 Nisan 1920'de Harbiye Nazırlığı görevini de vekaleten üstlenmiş̧i. Sarıhan, Kurtuluş Savaşı Günlü̈̆̈̈̈, Cilt: II, s. 493 .

${ }_{11}$ Alemdar, 24 Nisan 1336/1920, Nu: 488-2798; Cağglar, "Kuvâ-y1 İnzibatiye”, s. 345; Kuvâyı İnzibatiye'ye dahil kumandan, subay ve erler şu yemini yapıyorlardı: "Veli-yi nimetbi-minnetimiz, Padişahımı, Halife-i Müslimin Efendimiz hazretlerine ferman ve Irade-i Hümayunları dairesinde sadakatla, istikametle hizmet eyleyeceğime ve muhill-i namus her tüerlü ahval ve harekattan içtinab eyleyeceğime, bil-umum sekene-i ahalinin mal, irz, namus ve hayatlarını muhafaza ve uğur-ı Hümayunlarında hayatımı seve seve feda eyleyeceğime vallahi, billahi". Bkz. Mehmet Tevfik Bey, Mütareke Devri Hatıraları, s. 395; Gotthard Jaeschke, "Milliyetçiliğin ve Dinin İstiklal Harbindeki Rolleri”, Türk Dünyası Araştırmaları Dergisi, Sayı: 13, (Ăğustos 1981), Ankara, s. 196, (187-197). $\mathrm{Nu}$ : 511/10941

Alemdar, 29 Nisan 1336/1920, Nu: 493-2803; Peyam-ı Sabah, 29 Nisan 1336/1920, 
Kuvâ-y1 İnzibatiye birliklerinin, Kuvâ-yı Milliye'ye karşı yürüteceği askerî harekâtın başarılı olacağından emin olan Damat Ferit Paşa Hükümeti, Anadolu'da kaybolan nüfuzunu ve otoritesini kuvvetlendirmek amaciyla Anadolu Fevkalade Müfettişliği adıyla bir de müfettişlik kurdu ${ }^{103} .28$ Nisan tarihinde kurulan bu müfettişliğin başına da Müşir Zeki Paşa getirildi ${ }^{104}$. Müfettişliğin kuruluşu ile ilgili çıkartılan kararnamede "Anadolu'daki asayiş ve güvenliğin sağlanması için mülkî ve askerî konularda tam yetkili olmak üzere bir müfettişlik teşkil edildiğgi" belirtiliyordu. Diğer taraftan çıkartılan diğer bir kararname ${ }^{105}$ ile de, müfettişliğin görev ve yetkileri düzenlenmişti ${ }^{106}$. Bu kararnamede "müfettişliğin mülkî ve askerî yetkilerle donatıldiğl, asayiş ve güvenliğin temini için bütün Kuvâ-yı inzibatiye, zabıta ve gönüllü kit'aların müfettişliğin emri altında olduğu, müfettişlikçe gerekli görülen yerlerde örfi idare ilan edileceği; müfettişliğin faaliyetleri sırasında mülkî, askerî ve adlî makamlarla doğrudan görüşme yapabileceği; askerî teşkilatları lağvedip yeniden teşkile yetkili olduğu" belirtiliyordu ${ }^{107}$.

Anadolu Fevkâlade Müfettişi Zeki Paşa, göreviyle ilgili hazırlıklara başlamış, Anadolu'daki vilayetlere tamimler ve telgraflar göndererek görev ve yetkilerini bildirmeye başlamışt ${ }^{108}$. 4 Mayıs'ta bir beyanname yayınlayarak, yapacağı faaliyetleri etraflıca sıralamıştı. Bu beyannamede; ecdadın Osmanlı etrafında toplanarak muhteşem bir devlet kurduklarını hatırlatarak, kendilerinin de yine saltanat ve hilafet etrafinda toplanmaları gerektiğini belirtmiş ve “..değil tehlikeli anlarda, asûde zamanlarda bile nifak ve şikak bir hey'et-i milliyenin şüphesiz mucib-i felaketidir(...) Şu felaketli demlerimizde ihtiras peşinde koşanlar mutlaka bir ihanet-i milliyle,

103 Anadolu Fevkalade Müfettisliğinin kurulması Damat Ferit Pașa'nın Sadrazam, Hariciye Nazırı ve Harbiye Nazırı Vekili olduğu bir sırada 27 Nisan 1920'de Meclis-1 Vükela'da görüşülerek kararlaştırıldı. Bkz. Ali Arslan, "Anadolu Fevkalade Müfettişi Umumiliği" Ankara üniversitesi Türk Inkllâp Tarihi Enstitüsü Atatürk Yolu Dergisi, Cilt: 4, Sayı: 16, (Kasım 1995), s. 444. (443-453) 887.

${ }^{104}$ Takvim-i Vekâyi, 29 Nisan 1336/1920, Nu: 3840; Vakit, 29 Nisan 1336/1920, Nu:

${ }^{105} \mathrm{Bu}$ kararname 6 Mayıs 1920'de Padişah tarafından tasdik edilerek yürürlüğe girmisti. Bilahare 13 Mayıs 1920 de bu kararnameye zeyl olarak çıartılan diğer bir kararname ile müfettişliğin yetkileri artırılmıştı. Arslan, "Anadolu Fevkalade Müfettişi”, s. 444.

${ }^{106}$ Arslan, "Anadolu Fevkalade Müfettişi”, s. 444-445. Ayrıca Bkz. Zekeriya Türkmen, "Kuvâ-yı Millîye Hareketini Bastırmak Üzere İstanbul Hükümetinin Kurduğu Bir Teşkilât: Anadolu Fevkalâde Müfettişi Umumiliği”, Türk Tarihçiliği ve Prof. Dr. Aydın Taneri Armă̆ani, Ankara-1998, s. 468. (465-476)

7 Arslan, "Anadolu Fevkalade Müfettişi”, s. 445-447; Kararnamenin hükümleri için Bkz. Türkmen, "Anadolu Fevkalade Müfettisi”, s. 474-475, Ek II; Zekeriya Türkmen, Mütareke Döneminde Ordunun Durumu ve Yeniden Yapılanması (1918-1920), Türk Tarih Kurumu Basımevi, Ankara-2001, s. 266.

108 Alemdar gazetesinde yer alan bir haberde "müfettis Müsir Zeki Pasa'nın, göreviyle ilgili hazırlıklara başladı̆̆gl" bildiriliyordu. Bkz. Alemdar, 3 Mayıs 1336/1920, Nu: 5012801. 
Osmanlılığın izmihlaline çalışanlardır" diyerek kendisinin bu gibileri "memleketin selameti namina pençe-i kanuna teslim" edeceğini açıklamışt1 ${ }^{109}$.

Ankara'da Büyük Millet Meclisi'nin açıldığı günlerde, Anadolu'daki bütün otorite ve yetkilerini kaybettiğini gören Damat Ferit Paşa ve Hükümeti, ihdas ettiği Anadolu Fevkalade Müfettişliği ile bu gücü ve otoriteyi yeniden İstanbul'a kazandırmayı düşünmüsştü. Bu müfettişlik ihdası bir anlamda Padişah ve İstanbul Hükümeti'nin kanun hâkimiyetinin yani otoritesinin Anadolu'da yeniden sağlanmasına yönelik bir tedbiri idi. Fakat Damat Ferit Paşa, Kuvâ-yı İnzibatiye birliklerinden beklediği başarıyı sağlayamadı. Ahmet Anzavur, 10 Mayıs'ta Adapazarı, 13 Mayıs'ta Kandıra ve 15 Mayıs'ta Doğançay'ı ele geçirmeyi başard ${ }^{110}$. Fakat Anzavur'un bu ilerleyişi karşısında 23 Mayıs'ta Çerkez Ethem kumandasında başlayan karşı taarruz neticesinde Anzavur birlikleri mağlup edildi. Ayrıca 14 Haziran'da İzmit'ten tekrar harekâta geçen Kuvâ-yı İnzibatiye birlikleri de bir süredir Sapanca'da tertibat almış olan Ali Fuat Paşa'nın karşı taarruzu neticesinde mağlup edilmiştir. Neticede Kuvâ-yı İnzibatiye birlikleri İzmit'e gönderilen Gülcemal isimli vapurla 20 Haziran'da İstanbul'a geri götürüldüler. $\mathrm{Bu}$ başarısızlık üzerine Harbiye Nezareti tarafından 25 Haziran 1920 tarihinde Kuvâ-yı İnzibatiye birlikleri dağıtılmıştır ${ }^{111}$. Şunu da belirtmek gerekir ki Kuvâ-yı İnzibatiye birliklerinden birçok asker firar etmek suretiyle Kuvâ-yı Milliye'ye iltihak etmiştir. Hatta birçoğu bu firar esnasında yakalanıp yargılanmışlar ve birtakım cezalara da çarptırılmışlardır ${ }^{12}$.

Damat Ferit Paşa'nın IV. Sadaret'inde de pek çok Kuvâ-yı Milliye taraftarı askerî ve mülki görevlerinden azledilmişlerdir. Millî Mücadele taraftarı oldukları için görevlerinden azledilenlerden birkaçı: Resulayn Kaymakamı Fehmi Bey ${ }^{113}$, Ankara Defterdarı Yahya Galip Efendi ${ }^{114}$, Denizli Müftüsü Ahmet Hulusîi ${ }^{15}$, Bursa Müftüsü Ahmet Hamdi Efendi ${ }^{116}$,

109 Müşir Zeki Paşa'nın 4 Mayıs 1920 tarihli bu beyannamesi için Bkz. Alemdar, 5 May1s 1336/1920, Nu: 503-2803; Peyam-ı Sabah, 5 May1s 1336/1920, Nu: 517/10947; Vakit, 5 May1s 1336/1920, Nu: 893.

${ }_{110}$ Tï, Cilt: VI, s. 70.

11 TiH, Cilt: VI, s. 80. Kuvâ-yı İnzibatiye hakkında tafsilat için, Bkz. Sofuoğlu, Kuzeybatt Anadolu, s. 342-344, 350-371.

12 Kuvâ-yı İnzibatiye'den firar edip Kuvâ-yı Milliye'ye katılanlardan birkaçı için, Bkz. TíTE, Kutu No: 62, Belge No: 140; TíTE, Kutu No: 62, Belge No: 136; Takvim-i Vekâyi, 17 Temmuz 1336/1920, Nu: 3905.

${ }_{113}$ Takvim-i Vekâyi, 21 Nisan 1336/1920, Nu: 3833.

114 Takvim-i Vekâyi, 21 Nisan 1336/1920, Nu: 3833.

${ }^{115}$ Bab-1 Fetva Memurin Kalemi Müdüriyeti, Meşihat Makamına 1 Ağustos 1990 tarihli Ahmed Hulusi Bey'in azli ile ilgili bir yazı gönderdi. Bu yazıda; "Müftü Ahmet Hulusi'nin müftülük görevi ile bağdasmayan ve eskkva çetesi olan Kuvâ-yı Millive harekâtına silahlı olarak fiilen katıldı̆̆g, işlenen cinayet ve işkencelerin tertipleyicisi ve teşvikçisi olduğu güvenilir kaynaklardan ögrenildiğ $i$, bu nedenle de adıgeçen şifahen alınan bir "irade-i 
Isparta Müftüsü Hüseyin Hüsnü (Özadamar), Ușak Müftüsü Ali Rıza (Bodur), Burhaniye Müftüsü Mehmet (Tarhan), Antalya Müftüsü Ahmet Hamdi, Sinop Müftüsü İbrahim Hilmi Efendi ${ }^{117}$, Erkan-1 Harbiye Kaymakamı Yusuf Rasih Bey ${ }^{118}$, 14. Kolordu Kumandanı Yusuf İzzet Paşa, Miralay İzmirli İsmet, Miralay Bekir Sami Bey, İsmail Fazıl Paşa, Hüseyin Selahattin, 12. Kolordu Kumandanı Fahrettin Bey ${ }^{119}$, Manastırl1 Remzi Bey, Binbaşı İsmail Hakkı, Tolçalı Süleyman, Süvari Binbaşısı Asitaneli Adil, Binbaşı Rizeli Raşid Bey, Gelibolulu Bican Efendi, Piyade Binbaşısı Cemal Bey $^{120}$, Kartallı Hüseyin Avni Bey'dir ${ }^{121}$. Cafer Tayyar Paşa da 21 Nisan 1920 'de görevinden azledilmiştir ${ }^{122}$. Akşin'in verdiği bilgiye göre; Damat Ferit Hükümetleri tarafindan görevlerinden azledilen mutasarrıf ve kaymakamın sayısı otuzu buluyordu ${ }^{123}$.

Yine Damat Ferit Paşa'nın Kuvâ-yı Milliye hareketini ve bu hareketin lider kadrosunu yok etmek amaciyla verdiği amansız mücadelenin bir halkasını da, Kuvâ-yı Milliye hareketine sıcak bakan ve destekleyenlerin tutuklanmalarını ve İngilizler tarafından Malta'ya sürgüne gönderilmelerini sağlamak oluşturuyordu. 8 Nisan'da İngiliz Amirali de Robeck'le yaptı̆̆ 1 görüşmede ele alınan konulardan birisi de "bazı siyasi hasımlarının tutuklanması" olmuştu. Nitekim İngiliz Amirali bu görüşmeyle ilgili, Dışişleri Bakanı Curzon'a gönderdiği raporunda "Ayylldız Cemiyeti üyelerine" karşı ortaklaşa tedbirler almak amacıyla Ferit Paşa'nın bu kimselerin adlarını gizlice kendilerine bildirileceğinden bahsetmiştir ${ }^{124}$. Damat Ferit Paşa, 22 Nisan'da hazırladığı ve gizli tutulan "kara listeyi" İstanbul'daki Yüksek Komiser Vekili Amiral Webb'e vermiş ve listede yer alan isimlerin İtilaf devletlerince tutuklanarak Malta'ya gönderilmelerini talep etmiştir ${ }^{125}$. Listede tutuklanmaları istenenler arasında Kuvâ-yı Milliye

seniyye" ile görevinden azledildiği bildirilmektedir". Bkz. Ali Sarıkoyuncu, Millî Mücadele'de Din Adạmları, Cilt: 1, Diyanet İşleri Baş̧anlığı Yayınları, Ankara-1995, s. 123. ${ }_{16} \boldsymbol{B O A}, \boldsymbol{D H} . \dot{I} . \boldsymbol{U M}, 11-7 / 9-6 ; \boldsymbol{B O A}, \boldsymbol{D H}$. I. UM, 19-14/1-18; Ahmet Hamdi Efendi hakkında tafsilat için, Bkz. Günay Çağlar, "Millî Mücadele'de Fetvalar Olayına Değişik Bir Açıdan Bakış", Atatürk Üniversitesi Türkiyat Araştırmaları Enstitüsü̈ Dergisi, 75. Y1l Özel Say1s1, Say1: 11, Erzurum-1999, s. 268-270.

Ali Sarıkoyuncu, "Şeyhülislam Mustafa Sabri’nin Millî Mücadele ve Atatürk İnkılâpları Karşıtı Tutum ve Davranışları”, Atatürk Araştırma Merkezi Dergisi, Cilt: XIII, Sayı: 39, Kasım-1997, s. 794.

${ }_{11}$ BOA, BEO, Umumi No: 348269.

119 Takvim-i Vekâyi, 21 Haziran 1336/1920, Nu: 3883.

${ }^{120}$ Takvim-i Vekâyi, 13 Haziran 1336/1920, Nu: 3878.

${ }_{121}$ Takvim-i Vekâyi, 17 Temmuz 1336/1920, Nu: 3905.

122 Peyam-ı Sabah, 23 Nisan 1336/1920, Nu: 505/10935.

${ }^{123}$ Sina Akşin, İstanbul Hükümetleri ve Millî Mücadele -Mutlakıyete Dönüş (19181919)-, Cilt: 1, Tựrkiye İş Bankası Kültür Yayınları, Ankara-1998, s. 447.

${ }_{124} 4$ Şimşir, İngiliz Belgelerinde Atatürk, Cilt: II, s. 26. 211-212.

Şimşir, Ingiliz Belgelerinde Atatürk, Cilt: II, s. 92; Şimşir, Malta Sürgünleri, s. 
hareketinin önde gelen simalarından; Mustafa Kemal, Ali Fuat, Kazım Karabekir, İsmail Fazıl, Nihat Paşalar ile Cafer Tayyar, Behiç, Mehmet Selahattin, Selahattin Adil, Ömer Lütfi, Kazım, İsmet Beyler gibi miralay rütbesindeki isimler bulunuyordu ${ }^{126}$.

İngiliz Yüksek Komiser Vekili Amiral Webb konuyu ve tutuklanması istenen kiş̧ilerin yer aldığ listeyi, 22 Nisan'da İngiliz Karadeniz Orduları Başkumandanı General Milne'ye bildirmişti. Amiral Webb yazısında, listede yer alan bazı isimlerin İtilaf devletlerinin ulaşamayacakları bölgelerde olduğunu, bir kısmının da Türk makamlarınca tutuklanmalarının uygun olacağını, eski sadrazamlardan İzzet Paşa'nın tutuklanmasının uygun olmayacağını da kendi görüşü olarak General Milne belirtmiştir. İngiliz yetkililerinin kendi aralarındaki bu yazışmaları bilahare İngiliz Dışişleri Bakanlığı'na gönderilmişti. İngiliz Dışişleri'nin Damat Ferit Paşa'nın listesinde tutuklanması istenilen kişilerle ilgili değerlendirmeleri oldukça ilginçtir. Nitekim Mustafa Kemal Paşa'nın "tutuklanmasını" telkin etmenin saçma bir fikir olduğunu söyleyeceklerdir ${ }^{127}$. Yine de Yakup Şevki Paşa gibi listede yer alan birkaç kişi İngilizler tarafindan tutuklanarak Malta'ya gönderilmiştir ${ }^{128}$.

Damat Ferit Paşa, Kuvâ-yı Milliye'ye karşı bir yandan yukarıda bahsettiğimiz, siyasî ve askerî tedbirlere başvururken, diğer yandan bu hareketin ileri gelenleri hakkında da bazı plan ve tertiplere girişiyordu. $\mathrm{Bu}$ plan ve tertiplerin başında da, Millî Mücadele önderlerini hukukî anlamda da suçlu göstermek geliyordu.

\section{Kuvâ-yı Milliye İleri Gelenleri Hakkında Verilen İdam Kararları}

Damat Ferit Paşa, 4 üncü defa sadarete gelmesinden kısa bir süre sonra 8 Nisan'da İngiliz amirali De Robeck'le görüşmüştü. Bu görüşmede “milli hareketi bastırmak programıyla" başa geçtiğini belirten Damat Ferit Paşa, bu hareketin liderlerine karşı "Padişahın manevi nüfuzundan başka silah kullanacă̆ını" açıklamışt1 ${ }^{129}$.

Damat Ferit'in ifade ettiği bu başka silahlar çok geçmeden 10-11 Nisan günleri arka arkaya ilan edilen Şeyhülislâm Dürrizâde Abdullah Efendi

126 Bu isimlerin yanında Hasan Rıza, Ahmet İzzet, Galip paşalar ile Hayri Bey, Seyit Bey, Ahmet Rıza Bey ve Talat Paşa, Enver Paşa, Yakup Şevki Paşa ve Cavit Bey gibi isimlerde vardı. Bu liste için Bkz. Şimşir, Ingiliz Belgelerinde Atatürk, Cilt: II, s. 93; Şimşir, Malta Sürgünleri, s. 211-212. 214-2 125

Şimşir, Ingiliz Belgelerinde Atatürk, Cilt: II, s. 94; Şimşir, Malta Sürgünleri, s.

Y2. Yakub Şevki Paşa, 21 Nisan'da tutuklanmıştı. Bkz. Sarıhan, Kurtuluş Savaşı Günlü̈̆̈̈̈, Cilt: II, s. 494 ve Cilt: II, s. 28-29.

${ }^{29}$ Şimşir, Ingiliz Belgelerinde Atatürk, Cilt: II, s. 26. 
tarafindan yayınlanan "Fetvâ-yı Şerîfe" ile "Hükümet Beyannamesi" idi. Aslında bunlardan önce bizzat Padişahın, Damat Ferit Paşa'yı sadarete tayin ettiği "Hatt-l Hümayun" da; Anadolu'da milliyet namı altında yapılan karışıklıkların, ülkenin siyasi durumunu tehlikeye düşürdüğü, bunlara karş1 şimdiye kadar alınan barış yollu tedbirlerin fayda etmediğinden bahsedilerek "iğtişaşat-ı vâkıanın malum olan mürettib ve müşevvikleri hakkında ahkâm-ı kanuniyenin icrası" istenmiş ve aldatılarak bu harekete katılanlar hakkında genel af çıkartılacağı belirtilmişti ${ }^{130}$.

Şeyhülislamın fetvasında ise; Kuvâ-yı Milliye hareketi ileri gelenleri "hak tanımayan, cani, bagi, şaki ve aynı zamanda Saltanat ve Hilafet'i yıkmaya çalışanlar" olarak suçlanmakta, bunların öldürülmelerinin ise dinen meşru ve farz olduğu belirtilmekteydi ${ }^{131}$.

Damat Ferit Paşa'nın yayınlattığı Hükümet Beyannamesi'nde ise; bir takım kişiler olarak nitelendirilen Kuvâ-yı Milliye ileri gelenlerinin "yalnız hırs ve menfaat sevkile Teşkilât- Milliye ünvanı altında" fitne ve fesat hareketine giriştiklerinden bahsedilmekte ve yine bu isyanın elebaşlarının "payitaht ile Anadolu arasindaki muhabere (haberleşme) ve muvaredeyi (ilişkiyi)" kesmeye çalışarak en büyük vatan hainliğini yaptıkları belirtiliyordu. Beyannamede devamla, Kuvâ-y1 Milliye ileri gelenleri; anayasayı ve devletin kanunlarını ayaklar altına alan, Allah'ın emirlerine ve İslâm hukukuna karşı gelen kişiler olarak suçlanıyorlardı. Beyannamede bu kişiler yola gelmezlerse "şer-i şerif ve kanun-ı münif (kurallar) mucibince ve Hatt-ı Hümayun ile tebliğ olunan Irade-i Seniyye-i Hazret-i Hilafetpenahiye uygun olarak yok edileceklerdir" denilmekteydi.

Beyannamenin son kısmında ise, isyan harekâtının düzenleyicileri ve özendiricileri olarak ifade edilen Kuvâ-yı Milliye önderlerinin "iğfalat (kandirmalarına) ve tehdidatına (korkutmalarına)" kapilarak ve yaptıklarının sonucunun tehlikeli olacağını düşünmeyerek onlara katılanlardan, bir hafta içerisinde pişmanlıklarını açıklayıp, padişaha bağlılıklarını gösterenlerin af edilecekleri açıklanmaktaydı.

Damat Ferit Paşa, beyannamesini isyan olarak nitelendirdiği Kuvâ-y1 Milliye hareketinin "düzenleyicileri ve özendiricilerinin" (yani Kuvâ-y1 Milliye ileri gelenlerinin) ve onlarla birlikte hareket etmekte israr edecek olan "asilerin şer'an ve kanunen" yok edileceği ve bunların en ağır ceza ile cezalandırılacaklarını ilan ederek bitiyordu ${ }^{132}$.

${ }^{130}$ Hatt-1 Hümayun için Bkz. Takvim-i Vekâyi, 2 Nisan 1336/1920, Nu: 3820; İnal, Son Sadrazamlar, s. 2051-2052.

${ }_{31}$ Seyhülislam Dürrizade Abdullah'ın fetvası için Bkz. Takvim-i Vekâyi, 11 Nisan 1336/1920, Nu: 3824

${ }^{32}$ Beyanname için Bkz. Takvim-i Vekâyi, 11 Nisan 1336/1920, Nu: 3824 
Yukarıda belirttiğimiz, "Hatt-ı Hümayun", "Fetvâ-yı Şerife" ve "Hükümet Beyannamesi"nde yer alan ifadelerden; Padişah, Damat Ferit Paşa ve Hükümeti'nin Kuvâ-yı Milliye ileri gelenleri hakkında hukukî anlamda da bir şeyler yapacaklarının kesin işaretlerini vermektedir.

Damat Ferit Paşa Hükümeti'nin beyannamesinde belirtilen "bir hafta içinde pişman olarak, padişaha bağlılıklarını gösterenlerin affedileceğine" ilişkin sürenin bitmesinden sonra İstanbul gazetelerinde Kuvâ-yı Milliye ileri gelenlerinin "Divan-ı Harbi Örfi'ye" verildiklerine ilişkin haberler çıkmaya başlamıştı. Nitekim Alemdar gazetesi bu konuda "Hükümetin beyannamesi ile belirlenen, Anadolu'daki isyanın tertip ve teşvikçilerinden Mustafa Kemal ve hempaları, Divan-ı Harb-i Örfi'ye tevdi edilmiştir" haberini veriyordu ${ }^{133}$. Peyam-1 Sabah gazetesi ise "Mustafa Kemal ve hempalarl Divan-ı Harb-i Örfi'ye verildi" başlığılla bu haberi duyuruyordu ${ }^{134}$.

Böylece Kuvâ-yı Milliye ileri gelenleri haklarında, İstanbul'da Divan-1 Harb-i Örfi'de yargılama süreci başlamıştı.

A) Mustafa Kemal Paşa ve Bazı Kuvâ-yı Milliye Ileri Gelenleri Hakkında Verilen İdam Kararı

Mustafa Kemal Paşa ve bazı Kuvâ-yı Milliye ileri gelenlerinin yargılanmaları İstanbul'daki 1 Numaralı Divan-1 Harb-i Örfi'ce (İdare-i Örfiye 1. Divan-1 Harbi) yapılmıştı ${ }^{135}$. Bu mahkeme, Mütareke döneminin başlarından beri tehcir ve taktil davalarına bakıyordu ${ }^{136} .10$ Nisan 1920 'de bu Divan-1 Harb-i Örfi'nin başkanlığına Bursa eski valisi olan ve "KürtNemrut" lakabıyla tanınan Mustafa Paşa atanmışı ${ }^{137}$. Mahkemenin üyelerini

133 Alemdar, 23 Nisan 1336/1920, Nu: 491-2791; Aynı mahiyette haberi Vakit'te de görüyoruz. Bkz. Vakit, 23 Nisan 1336/1920, Nu: 881.

${ }_{135}$ Peyam-ı Sabah, 23 Nisan 1336/1920, Nu: 505/10395.

135 İstanbul'daki 1 Numaralı Divan-1 Harb-i Örfi (İdare-i Örfiye 1. Divan-1 Harbi) hakkında yapılmış bir çalışma için Bkz. Metin Ayışığı, "Bir Askeri Mahkeme: İstanbul Birinci Divan-1 Harbi Örfîsi" Yedinci Askeri Tarih Semineri Bildirileri I, Ankara-2000, s. 381-390.

36 İstanbul 1 Numaralı Divan-1 Harbi Örfi'de tehcir ve taktil suçlamalarıyla ilgili görülen davalar için Bkz. Tarık Zafer Tunaya, Türkiye'de Siyasal Partiler, Cilt. III, Hürriyet Vakf1 Yayınları, Istanbul-1989, s. 556-565; Taner Akçam, Insan Hakları ve Ermeni Sorunu (Ittihat Terakki'den Kurtuluş Savaşı'na), İmge Kitabevi Yayınları, İstanbul-1999; Taner Akçam, "Divan-1 Harbi Örfi'lerin Kurulması-İstanbul Yargılamaları", Tarih ve Toplum, Sayı: 137, (Mayis 1995), s. 47-52.

37 Nemrut Mustafa Paşa'nın atanmasıyla ilgili İrade-i Seniyye için Bkz. Takvim-i Vekâyi, 10 Nisan 1336/1920, No: 3829.

Tevfik Paşa'nın son sadareti döneminde, 14 Kasım 1920'de İstanbul Bir Numaralı divan-1 harbi eski başkanı "Nemrut" lakaplı Mustafa Paşa ve üç arkadaşını tevkif etmiş ve 1 Subat 1921 tarihinde Yüksek Askeri Mahkeme tarafından t ay hapis cezasına carptırılmıstı. Ancak Padişah Vahideddin tarafindan 7 Şubat 1921 tarihli bir irade ile Nemrut Mustafa Paşa affedilmiştir. Ayışı̆̆ı, "İstanbul Birinci Divan-ı Harbi Örfîsi”" s. 388.; Nemrut Mustafa 
ise; erkânı harbiye mirlivalarından Recep Paşa, 2 Numaralı Divân-1 Harb-i Örfi azasından Süvari Miralay Recep Bey, Miralay Ferhat Bey ve Kaymakam Fettah Bey'den oluşturmuştur ${ }^{138}$. Hükümet, 23 Nisan 1920 tarihinde kabul ettiği kararname ile "ülkenin içinde bulunduğu durum"u bahane ederek Divân-1 Harb-i Örfilere olağanüstü yetkiler vermiştir. Bu yeni düzenlemeye göre mahkeme; önceden baktığı tehcir ve benzeri davalara ilaveten ülkenin asayişini bozup, iç ve dış emniyetini ihlal edenleri yargılamakla da yetkili kılınmışıır ${ }^{139}$. Nitekim devletin kurumları da bozulan asayişin düzelmesinin, ancak Kuvâ-yı Milliyecilerin yargılanıp tenkili ile mümkün olacağını düşünmektedirler. Mesela İstanbul Emniyet Genel Müdüriyeti'nden Adliye Nezareti'ne gönderilen 22 Mayıs 1920 tarihli bir yazıda; "Millî Blok, Millî Kongre, Millî Birlik, Millî Harekât, Kuvâ-y1 Milliye adı altında olarak Osmanlı Devleti tebaasını ve memleket halkını Padişah ve Hükümet aleyhine silahlı olarak isyan ettirip bi'l-vasıta bütün Anadolu'da insan öldürme, mal yağmalama ve tarife sığmaz çeşitli cinayetler işlemek suretiyle aslında halifelik makamının ve bütün İslam aleminin razı olmamasına ve karşı çıkmasına rağmen devleti içine sürükledikleri Umûmî Harp'te uğranılan feci yenilgi neticesi olmak üzere hükümetin, yükümlü tutulduğu ve siyasî hayatını mahveden barış şartlarını galip devletler nezdinde def'ine veya hiç olmazsa mümkün olduğu kadar hafifletilmesine bütün siyasî mesaisini harcamaya mecbur bulunduğu en mühim dakikalarda olsun zulüm kılıçlarının artıkları bulunan milletten utanmaları ve yaptıklarına pişman olmaları din ve insanlık icabı iken tam tersine Umûmî Harp esnasında işledikleri ve işlettikleri cinayetlere ara vermeksizin isyanlarını günden güne hızlandırmak suretiyle iç emniyeti karmakarışık ve bütün doğunun siyasî ve insanî hayatına suikast eden adları ilişik listede yazılı kimseler, halen cinayet ortakları bulunan isyan ve fesat erbabı ile faaliyet ve haberleşmede bulundukları sabit olduğundan bozulan sükûn ve asayişin geri gelmesinin ve devamının sağlanması bu kişilerin bir dakika evvel yargılanıp kanunî cezalarının icrasına bağlı bulunduğu"140 belirtilmekte ve "ülkenin içinde bulunduğu asayiş sorununu çözmek" için Mahkeme'nin derhal harekete geçmesi beklenmektedir.

Paşa'nın tutuklanarak yargılanması ile ilgili ayrıntılı bir bilgi olarak bkz. Feridun Ata, Bir İşbirlikçinin Portresi Nemrut Mustafa Paşa, Temel Yay., İstanbul 2008, s. 66-78. ${ }^{38}$ Ferudun Ata, İsgal İstanbul'unda Tehcir Yarglamalart, Türk Tarih Kurumu Basımevi, Ankara-2005, s. 256-257.

139 Ata, Tehcir Yargllamalari, s. 258.

140 Ata, That Sertoğlu, "Millî Mücadele'ye Yardım Ettikleri İçin Cezalandırılmak İstenenlere Dair Yayınlanmamıs Belgeler", Hayat Tarih Mecmuası, Y11: 14, Say1: 2, Subat1978, s. 47; Ayrıca Kuvâ-yı Milliyeci oldukları için ve Milli Mücadele'ye yardım ettikleri için cezalandırılmak istenen 88 kişinin isimleri için, Bkz. Aynı Yer, s. 48-49. 
Kuvâ-yı Milliye mensuplarını yok etmeyi planlayan, bu amaca ulaşmak noktasında yapısında da değişikliklere tabi tutulan ve Nemrut Mustafa Paşa Divanı lakabıyla şöhret kazanan bu Divan-1 Harbi Örfi, Kuvâ-yı Milliye'yi destekledikleri için İstanbul' da "teğmenden generallere, memurdan, emniyet amirine kadar" birçok devlet adamını yargılamış ve yine Kuvâ-yı Milliye yanlısı yüzlerce subayı gıyaplarında idama mahkûm etmiştir ${ }^{141}$.

Zaten haklarında Meclis-i Vükela'ca, Harbiye, Dâhiliye ve Hariciye nezaretlerine verilen emirler gereğince tutuklama kararı bulunan, yakalandıkları anda hemen İstanbul'a gönderilmeleri istenen ${ }^{142}$ Mustafa Kemal Paşa ve Kuvâ-yı Milliye ileri gelenlerinin yargılamalarına 24 Nisan'da başlanmıştır. Nemrut Mustafa Paşa Divanı tarafından gıyaplarında sürdürülen davanın görüşmeleri 11 Mayıs'ta tamamlanmış ve karar açıklanmıştır. Nitekim 13 Mayıs tarihli Peyam-1 Sabah gazetesi "Divan-1 Harbi Örfi Riyasetinden" başlıklı haberiyle Kuvâ-yı Milliyeciler hakkında açılan davanın sonuçlandırıldığını belirtmiş ${ }^{143}$ ve "Iddam Kararı-Mustafa Kemal ve Arkadaşlarının İdamı" başlığıyla da mahkemenin verdiği hüküm mazbatasının yani karar tutanağının tamamını vermiştir ${ }^{144}$.

İstanbul 1 Numaralı Divan-1 Harbi Örfi'nin Kuvâ-yı Milliye ileri gelenleri hakkında açmış olduğu ve idam kararı vererek sonuçlandırdığı bu ilk davada yargılananlar şu isimlerden oluşuyordu: Mustafa Kemal Paşa (Üçüncü Orduyu Hümayun Müfettişliği'nden azledilmiş ve askerlik görevinden çıkartılmış), Kara Vasıf Bey (Yirmi Yedinci Fırka Kumandanı ve Miralaylıktan emekli), Ali Fuat Paşa (Yirminci Kolordu'nun Eski Kumandanı ve Mirliva), Midillili Alfred Rüstem Bey (Eski Washington Sefiri ve Eski Ankara Mebusu), Dr. Adnan Bey (Eski Sihhıye Müdürü), Halide Edip Hanım (Eski Darülfünun Garp Edebiyatı Muallimesi) ${ }^{145}$.

Altı kișiden oluşan bu ilk idam kararında ilk dikkati çeken isim elbette ki Millî Mücadele hareketinin lideri ve bu kararın verildiği tarihte Büyük

${ }^{141}$ Ayışı̆̆ 1 , “İstanbul Birinci Divan-ı Harbi Örfîsi”’ s. 386.

${ }_{142} \boldsymbol{B O A}, \boldsymbol{M V}, 216 / 95$; Alemdar gazetesindeki bir yazıda da; Mustafa Kemal ve Rauf Beylerin hareketine destek veren Demirci Mehmet Efe ve Hacı Sükrü Bey'in ve ayrıca bu harekete destek veren kim olursa olsun herkesin yakalanarak Divân-1 Harbe sevkinin Dahiliye Nezareti'nce Vilayetlerden istendiği hakkında bilgi verilmektedir. Bkz. Alemdar, 31 Temmuz 1335/1919, Nu: 127-1527.

143 Peyam-l Sabah, 13 May1s 1336/1920, Nu: 525/10955; Alemdar, 13 May1s 1336/1920, Nu: 507-2816.

${ }_{44}$ Peyam-ı Sabah, 13 May1s 1336/1920, Nu: 525/10955; Alemdar bu haberi "Mustafa Kemal ve Hempalarının İdam Kararı" başlığıyla okuyucularına duyurmuştur. Bkz. Alemdar, 13 May1s 1336/1920, Nu: 507-2816.

${ }_{45} \mathrm{Bu}$ isimlerin yer aldığı İrade-i Seniyye için Bkz. Takvim-i Vekâyi, 27 Mayıs 1336/1920, Nu: 3864; Atatürk'le ilgili Arşiv Belgeleri, s. 83, Belge No: 87. 
Millet Meclisi Reisi ${ }^{146}$ ve aynı zamanda İlk İcra Vekilleri Heyeti Reisliği ${ }^{147}$ görevini de üstlenmiş olan Mustafa Kemal Paşa'dır ${ }^{148}$. Yine aynı "idam kararı"nda idama mahkûm edilmiş olan Adnan Bey de (Adıvar) Sıhhıye ve Muaveneti İçtimaiye Vekâletine (Sağlık Bakanı) atanmıș bulunmaktaydı. Mustafa Kemal Paşa ve arkadaşlarının işgallere karşı bir direniş hareketi oluşturmaları ve işgalci kuvvetlerle mücadeleye girişmeleri Damat Ferit Paşa Hükümeti tarafından bir isyan olarak algılanmış, nihayetinde de "isyancılar" Divân-1 Harbi Örfi'ye sevk edilmişlerdir. Divân-1 Harbi Örfi'de gıyaplarında görülen dava da Nemrut Mustafa Paşa heyeti tarafından idam cezasına çarptırılmışlardır. Nemrut Mustafa Paşa ve heyetine göre; Mustafa Kemal Paşa ve arkadaşları, Osmanlı Devleti'nin varlığına ve birliğine karşı isyan etmiş ve en ağır şekilde cezalandırılmaları gereken kişilerdir. Nitekim açıklanan idam kararı; "Kuva-yı Milliye unvanı tahtında çıkardıkları fitne ve fesadın ve Kanuni Esasî hilâfinda ahaliden cebren para toplamak ve asker almakta ve hilâfina hareket edenlere işkence ve cefaya cüret gibi fesayih irtikâp etmek suretiyle emniyet-i dâhiliyeyi ihlâl eyleyenlerin mürettip ve müssevviklerinden" ${ }^{149}$ olmakla suçlamakta ve bu cümlelerle başlamaktadır. Açılanan ve gazetelerde de yayınlanan bu idam kararında, idam cezasına çarptırılan bu altı kişi hakkında tahkikat yapıldığ 1 belirtilmekte ve yapılan tahkikat neticesinde de; isyankâr, devletin varlığı ile ilgili sorunları olan kişilerle birlik ve beraberlik içerisinde olduklarının görüldüğü ifade edilmiştir. Yine isyancılarla birlik olmaları hasebiyle, "teba-ı sadıka-ı şahaneden" olan masum ve saf Anadolu halkını kandırdıkları da bu idam kararında Mustafa Kemal ve arkadaşlarına yöneltilen suçlamalardan bir kısmıdır. Divân-1 Harbi Örfi tarafından açıklanan idam kararının gerekçesine

${ }^{146}$ Mustafa Kemal Paşa, Büyük Millet Meclisi’nin 24 Nisan 1336/1920 günü yapmış olduğu beşinci oturumda Büyük Millet Meclisi Başkanlığına aday gösterilmiş ve yapılan oylama sonucu, bessinci oturumda bulunan 120 mebustan 110'unun oyunu alarak Meclis Başkanlığına seçilmişti. Bu seçimle ilgili olarak Bkz. TBMM $\boldsymbol{Z C}$, Devre I, İçtima Senesi I, Cilt: 1, 3. Basılış, TBMM Matbaası, Ankara-1959, s. 38.

47 Büyük Millet Meclisine Ankara Mebusu olarak katılan Mustafa Kemal Paşa, 24 Nisan'da "teşkilâtı Hükümet hakkında" bir teklif sunmuştu. Bu teklifin 4 üncü maddesinde "Türkive Büyük Millet Meclisi tesrîi ve icrai salâhiyetleri câmidir Meclisten tefrik ve tevkil edilecek bir heyet umuru Hükümeti rüyet eder. Meclis Reisi be heyetin de reisidir." denilmekteydi. TBMM ZC, Cilt: 1, 24. 4 1336/1920, İ: 2, C: 3, s. 32.

1482 Mayıs 1920'de Büyük Millet Meclisi İ́cra Vekillerinin seçilmesine dair 3 Numaralı kanunu kabul ederek ilk İcra Vekillerini seçip Hükümeti kesin olarak kurduktan sonra Mustafa Kemal, Büyük Millet meclisi sifatıyla İcra Vekilleri heyeti toplantılarına da başkanlık etmeye başladı. 20 Ocak 1921 tarihinde teşkilatı esasiye Kanunu ile İcra vekilleri heyeti reisliği makamı ihdas edilip Fevzi Paşa bu göreve seçilinceye kadar İcra vekilleri heyeti reisliğini bizzat yaptı. 5 Mayıs 1920 tarihinde Türkiye Büyük Millet Meclisinin ilk kabinesi Mustafa Kemal Paşa başkanlığında toplandı. Bkz. İhsan Ezherli, Türkiye Büyük Millet Meclisi (1920-1998) ve Osmanlı Meclis-i Mebusant (1887-1920), 2. Bask1, TBMM Kültür, Sanat ve Yayın Kurulu Yayınları, Ankara-1998, s. 44.

Peyam-l Sabah, 13 May1s 1336/1920, Nu: 525/10955; Alemdar, 13 May1s 1336/1920, Nu: 507-2816. 
göre Mustafa Kemal Paşa ve arkadaşları; senelerden beri eşkıyalıkla meşgul olan şahıslarla birlik içerisinde olmak, I. Dünya Savaşı zamanında birçok fecaat işleyen, tehcirle birlikte de Müslüman ve gayr-1 müslim pek çok Osmanlı tebaasını yok edip "emvâl-i menkule" ile "gayr-i menkulleri" ni gasp eden ve Osmanlı Devleti'ni dünya nazarında küçük düşüren İttihat ve Terakki ile ittifak etmek, Kanun-1 Esasi aleyhine hareket etmek, halkı zorla silah altına almak, halktan zorla vergi toplamak, kendilerine karşı gelenlere akla gelmeyecek işkenceler uygulamak ve mallarını gasp etmek, birçok kasaba yakıp yıkmak ve masum halkını da katletmekle suçlanmaktadırlar. Ayrıca Anadolu'nun çeşitli yerlerinde görev yapan Osmanlı Devleti yetkililerinin yani sivil ve askerî memurların da görev yapmalarına engel olunduğu, onların görev mahallerinde terke mecbur edildikleri belirtilmektedir. Görevlerinden terke mecbur edilen memurların yerlerine de kendi yakınlarından kişileri memur ettikleri dile getirilmektedir. Ziraat Bankaları, postaneler, belediyeler ve mal sandıkları ile eytam sandıklarında pek çok külliyetli miktarları gasp ettikleri ve böylelikle kendi iktidarlarını sağlamaya çalıştıkları iddia edilmektedir. "Fesatamiz" ve "fitneengîz" nutuklar irat etmek, beyannameler neşretmek, Devlet' in asayişini bozmak ve "Hilafet", "Saltanat" ve "Memâlik-i Osmaniye"nin muhaberatını kesmekle suçlanan Mustafa Kemal Paşa ve arkadaşları nihayetinde de asker ve halkı Hükümet aleyhine isyana teşvik etmekle suçlanmaktadırlar. Halkı isyana teşvik etmekle "hükûmetin gayet mühim ve nazik olan vaziyet-i siyasiyesini ihlâle cüret ettikleri”"nin açıkça görüldüğünden bahsedilmektedir. Hükümet'in itilaf Devletleri nazarında zor durumda bırakıldığında bahsedilmekte "ülkenin içinde bulunduğu" durumdan dem vurulmakta ve nihayet ülkenin kötü gidişatının tek müsebbibi olarak Mustafa Kemal Paşa ve arkadaşları gösterilmektedir ${ }^{150}$.

Açıklanan idam kararında Ali Fuat Paşa'nın Kuvâ-yı Milliye'nin kumandanı olduğundan bahsedilmekte ve "Fuat Paşa'nın bizzat kuvve-i müsellah-ı bağiyenin kumandanlı̆̆ında bulunmuş olduğu şahadat-l mevcudeden ve kendilerinin neşretmiş oldukları beyanname-i vesair evrakmatbua münderecatından" anlaşıldığ 1 dile getirilmektedir ${ }^{151}$.

Nihayetinde Mustafa Kemal Paşa ve arkadaşları, Mülkiye Ceza Kanunname-i Hümayunu'nun 45. Maddesinin 1. F1krası, 55. Maddesinin 4. Fıkrası ve 56 Maddesi mucibince idam cezasına çarptırılmışlardır ${ }^{152}$. Gıyabî

150 Peyam-l Sabah, 13 May1s 1336/1920, Nu: 525/10955; Alemdar, 13 May1s 1336/1920, Nu: 507-2816.

151 Peyam-1 Sabah, 13 May1s 1336/1920, Nu: 525/10955; Alemdar, 13 May1s 1336/1920, Nu: 507-2816.

${ }^{152}$ Mülkiye Ceza Kanunname-i Hümayunu'nun ilgili maddeleri şöyledir: 45. Maddenin 1. F1krası: Eşhas-1 müteaddide bir cinayet veya cünhayı müttehiden ika eder veyahut ef'al-i 
olarak yargılanan Mustafa Kemal Paşa ve arkadaşlarının mallarının da haczedilmesine "glyaben ve müttefikan karar veril"miştir ${ }^{153}$.

Millî Mücadele Hareketi'nin önderi Mustafa Kemal Paşa ve arkadaşları hakkında Nemrut Mustafa Paşa Divanı'nca verilen bu idam kararı Sadrazam ve Harbiye Nazırı Vekili olan Damat Ferit Paşa tarafından 16 Mayıs'ta Padişah'a sunulmuş ${ }^{154}$ ve nihayet 24 Mayıs 1920 tarihinde Padişah tarafindan onaylanmak ${ }^{155}$ suretiyle yürürlüğe girmiştir. 24 Mayıs'ta onaylanan Mustafa Kemal Paşa ve arkadaşları hakkındaki idam kararına ilişkin “Irade-i Seniyye” 27 Mayıs'ta Takvim-i Vekâyi' de yayınlanmıştır ${ }^{156}$.

\section{B) Fevzi Paşa (Çakmak) Hakkındaki Verilen İdam Kararı}

Mustafa Fevzi (Çakmak) Paşa ${ }^{157}$, Millî Mücadele Hareketi'ne sonradan katılmasına rağmen başından itibaren Millî Mücadele'nin gerekliliğine inanan ve bu konuda Mustafa Kemal Paşa ile hem fikir bir kişiliktir. 24 Aralık 1918 tarihinde Erkân-1 Harbiye-i Umumiye Reisi (Genelkurmay

müteaddideden mürekkep olan bir cinayet veya cünhada bir takım eşhasdan her biri cürmün husulü maksadıyla ef'ali mezbûreden birini veya birkaçını icra eylerse eșhas-1 mezkûreye hemfiil denilir ve cümlesi fail-i müstakil gibi mücazat olunur. 55. Maddesinin 4. F1krasi: Her kim bizzat veya bilvasıta teba-i Devlet-i Aliyye ve sekene-i memâlik-i mahruseyi Zâti Hazreti Padişahî veyahut Hükûmet-i Osmaniye aleyhine müsellehan isyan ettirmek üzere tahrik edip de maksadı olan kaziyye-i isyan ile fiile çıkar ise idam olunur. 56. Maddesi: Her kim memalik-i Mahruse ahalisini yekdiğeri aleyhine silahlandırarak çıanlarla tahrip ve izaba yahut mahallerde gasb ve garât ve tahrib-i memleket ve katl-i nüfus ef'alini ikaa mütecasir olup da kaziyye-i fesat tamamiyle fiile çıkar veyahut madde-i fesadın icrasına başlanmış olur ise ol kimse kezalik idam olunur. Bkz. Peyam-ı Sabah, 13 May1s 1336/1920, Nu: 525/10955; Alemdar, 13 May1s 1336/1920, Nu: 507-2816.

153 Peyam-l Sabah, 13 May1s 1336/1920, Nu: 525/10955; Alemdar, 13 May1s 1336/1920, Nu: 507-2816.

${ }_{154}$ Atatürk ile İlgili Arşiv Belgeleri, Belge No: 85, s. 195. 347564.

155 Atatürk ile Ilgili Arşiv Belgeleri, Belge No: 87, s. 197; BOA, BEO, Umumî No:

${ }_{156}$ Takvim-i Vekâyi, 27 May1s 1336/1920, Nu: 3824; Vakit, 28 May1s 1336/1920, Nu: 901; Mustafa Kemal ve arkadaşları hakkında verilen idam kararının Mustafa Kemal Paşa tarafından nasıl karşılandığının anlaşılması açısında Halide Edip Hanım'ın hatıratına bakmak faydalı olacaktır: "Büyük odaya gittiğimde Mustafa Kemal Paşa ile Dr. Adnan el ele yazlhanenin yaninda oturuyorlar, Albay Ismet de yazıhaneye dayanmis, ayakta duruyordu. Dr. Adnan'a bu yeni şerefi nasıl karşıladığını sorduğum zaman, Mustafa Kemal Paşa Adnan'a dönerek: "Bizi mahkum edenlerin hiçbir siyasî değeri yok. İdama mahkum olmak hoșuma gitmedi. Sen ne düșünüyorsun?" diye sordu. Adnan da: "Benim de hoșuma gitmedi" dedi. Ben tekrar: "Bu karar şöhretimizi artıracaktır." Dedim. Albay İsmet dedi ki: "Tersine, onların memlekette siyasî kıymeti vardır. İstanbul ve İmir gibi illerde bize karşı sevgi artarsa da, henüz kararlarını vermemiş olan halk arasında kötü etki yapar. Özellikle ihtilal halinde olan yerlerde Padişahın ve İngilizlerin "teveccühünü" kazanmak isteyenler hücuma geçeceklerdir. Biz İstanbul gazetelerinin bu günlerde Anadolu'ya girmesine engel olmallyzz." Bkz. Halide Edip Adıvar, Türk'ün Ateşle Imtihanı, 11. Basım, Atlas Kitabevi, Istanbul-1994, s. 115 .

${ }^{i 57}$ Fevzi Paşa'nın askerî ve siyasî faaliyetleri hakkında genis bilgi için, Bkz. Hayrullah Gök, Mareşal Fevzi Çakmak'ın Askerî ve Siyasî Faaliyetleri (1876-1950), Genelkurmay Basimevi, Ankara-1997, s. 1-84. 
Başkanı) olan Fevzi Paşa, İzmir'in işgal edileceği haberlerinin geldiği bir ortamda her türlü işgal hareketine "ateşle karşı koymak lâzım geldiğini" beyan etmiştir ${ }^{158}$. İşgallere millî mukavemetle karş1lık verilmesi gerektiği inancında olan Fevzi Paşa, İtilaf Devletlerinin baskıları neticesinde Damat Ferit Paşa Hükümeti tarafından 14 Mayıs 1919'da görevinden alınmıştır ${ }^{159}$. Daha sonra Fevzi Paşa 1. Ordu Kıtaatı Müfettişliği görevine tayin edilmiştir ${ }^{160}$. Mustafa Kemal Paşa 15 Mayıs 1919'da vedalaşmak maksadıyla Fevzi Paşa'yı ziyaret etmiştir. Bu ziyaret esnasında alınan kararlara göre; üç ordu müfettişliğinin teşkil edilmesi, silahların teslim edilmemesi, Anadolu'da millî bir iradenin vücuda getirilmesi ve Kuvâ-yı Milliye'nin vücuda getirilmesi neticesinde işgallere karşı mukabil taarruza geçilmesi kararlaştırılmıştır ${ }^{161}$. Nihayetinde Fevzi Paşa 3 Şubat 1920 tarihinde Harbiye Nazırlığı'na atanmıştır ${ }^{162}$. Fevzi Paşa Harbiye Nazırı olur olmaz Anadolu'nun ihtiyaç duyduğu silah ve cephanenin gizli yollarla gönderilmesi işinde büyük gayretler sarf etmiştir. İstanbul'un işgal edilmesi ve Salih Paşa Hükümeti'nin de 2 Nisan 1920'de istifa etmesi sonucu açığa alınan Harbiye Nazırı Fevzi Paşa "artık yapacak işinin kalmadĭ̆ Anadolu'ya geçmiş, daha kendisi Ankara'ya vasıl olmadan Büyük Millet Meclisi azalığına seçilmiştir ${ }^{163}$. Fevzi Paşa, 2 Mayıs 1920'de İcra Vekilleri Heyeti içerisinde Müdafaa-i Milliye Vekilliği’ne (Millî Savunma Bakanı) seçilmiştir ${ }^{164}$.

Fevzi Paşa'nın Harbiye Nazırlı̆̆ı'ndan alındıktan sonra Anadolu'ya geçmesi ve ilk İcra Vekilleri Heyeti içerisinde Müdafaa-i Milliye Vekili sıfatıyla yerini alması Damat Ferit Paşa Hükümeti tarafından tepki ile karşılanmıştır. Nihayetinde Fevzi Paşa, 1. Divân-1 Harbi Örfi'ye verilmiş ve gıyabından yargılanmıştır. Gıyabında yürütülen dava 24 Mayıs 1920'de sonuçlanmış ve 1. Divân-1 Harbi Örfi tarafından açıklanmıştır ${ }^{165}$. Divân-1 Harbi Örfi tarafından açıklanan karara göre Fevzi Paşa; "Kuvâ-yı Milliye namı altına çıkarılan fitne ve fesadın mürettiplerine iltihak etmek" için İstanbul'dan firar etmek, 27 Nisan'da Ankara'ya ulaşması ile birlikte

\footnotetext{
${ }^{158}$ Gök, Fevzi Çakmak, s. 25-26.

${ }^{159}$ Gök, Fevzi Çakmak, s. 28.

${ }^{160}$ Gök, Fevzi Çakmak, s. 28.

${ }^{161}$ Selahattin Tansel, Mondros'tan Mudanya'ya, Cilt: 1, İstanbul 1991, s. 232-233(37 No'lu dipnot); Gök, Fevzi Çakmak, s. 28.

${ }_{62}$ Gök, Fevzi Çakmak, s. 31; Fevzi Paşa'nın Harbiye Nazırlı̆̆ı'na atanması Mustafa Kemal Paşa tarafından da olumlu karşılanmıştır. Nitekim 7 Şubat 1920'de Rauf Bey'e gönderdiği bir şifre telgrafta; “..bizce Cemal Paşa'nın ayrılması bir sorun değildir. En çok Fevzi Paşa ile çalışabiliriz kanısındayız...” demiştir. Bkz. Atatürk, Nutuk, Cilt: III, (19191927)Belgeler, Yay. Haz. İsmet Gönülal, Ankara-1984, s. 187.

163 Gök, Fevzi Çakmak, s. 32-39.

${ }_{164}$ Hakimiyet-i Milliye, 5 May1s 1336/1920, Nu: 27.

165 Alemdar, 26 May1s 1336/1920, Nu: 520-2830; Vakit, 26 May1s 1336/1920, Nu: 899; İkdam, 27 May1s 1336/1920, Nu: 8364.
} 
"ahaliyi hükûmet-i meşrua-i Osmaniye aleyhine müsellah-ı isyana teşvik ve gayrete mücaseret eden güruh-u eşkiyaya iltihak ve bügat-l merkûme tarafindan teşkil edilmiş ve Büyük Millet Meclisi namı verilmiş olan Meclise dâhil ol"mak ve İstanbul'un işgali hakkında fesad-amîz bir nutuk irat etmek $^{166}$ ve ayrıca Müdafaa-i Milliye Vekilliği namı ile Harbiye Nazırlığı'na soyunmakla suçlanmaktadır ${ }^{167}$. İdam kararında Fevzi Paşa ve Kuvâ-yı Milliye Hareketi, memleketin içerisinde karışıklık çıkarmak suretiyle "devletin vaziyyet-i siyasiye ve i'tibar-ı maliyesinin bir kat daha haleldar olmasina sebebiyet ver"enler olarak dile getirilmektedir. Ayrica bu idam kararında; Fevzi Paşa nankörlükle suçlanmaktadır: Fevzi Paşa'nın az bir zaman içinde Feriklik (Orgenerallik) rütbesine kadar ulaştığından, Osmanlı Devleti'nin nimetleriyle donanıp Harbiye Nazırlı̆̆ı'na kadar yükseldiğinden bahsedilmekte ve bu durumun nankörlükten başkaca bir şey olamayacağ vurgulanmaktadır. Kararda Fevzi Paşa'nın Hilafet ve Saltanat'a açıcça karşı koyduğu ve mücadeleye giriştiği, "baği $i$ lere ise sadakatle bağlı olduğundan dem vurulmakta, Fevzi Paşa'nın bu durumunun Dersaadet'te bulunup Harbiye Nazırı olduğu sıralarda dahi vaki olduğu, "baği" olarak dillendirilen Mustafa Kemal ve arkadaşları yani Kuvâ-yı Milliye ile "teşrik-i mesai" içinde bulunduğu dile getirilmektedir ${ }^{168}$.

Yukarıda anlatılan suçlardan hükümlü olan Fevzi Paşa'nın, suçlarının “ăgırlı̆̆l” dolayısıyla Mülkiye Ceza Kanunname-i Hümayunu'nun 45. Maddesi'nin 1. F1krası, 55. Maddesi'nin 4. F1krası ve 56. Maddesi mucibince askerlik mesleğinden çıkartılmasına, haiz olduğu bütün nişan ve madalyalarının alınmasına, firarda bulunması hasebiyle "emvalinin haczettirilmesi" ne ve idamına karar verilmiştir ${ }^{169}$.

Fevzi Paşa hakkında 1. Divân-1 Harbi Örfi tarafından 24 Mayıs'ta verilen yukarıdaki karar 27 Mayıs 1920'de Padişah Sultan Vahdettin tarafından çıkarılan bir "İrade-i Seniyye" ile onaylanmış ve yürürlüğe girmiştir ${ }^{170}$. Bu "İrade-i Seniyye" sureti 30 Mayıs’ta Takvim-i Vekâyi’de yayınlanmıştır ${ }^{171}$.

${ }^{166}$ Fevzi Paşa'nın Divân-ı Harbi Örfi tarafından idam kararında belirtilen dolayısıyla da idam cezasına çarptırılmasında etkili olan Meclis’te yapmış olduğu konuşma metni için, Bkz. Atatürk'ün Tamim Telgraf ve Beyannameleri IV, Atatürk Kültür, Dil ve Tarih Yüksek Kurumu Atatürk Araştırma Merkezi Yay., Ankara 1991, s. 326-327.

167 Alemdar, 26 May1s 1336/1920, Nu: 520-2830; Vakit, 26 May1s 1336/1920, Nu: 899; İkdam, 27 Mayıs 1336/1920, Nu: 8364.

${ }^{68}$ Alemdar, 26 May1s 1336/1920, Nu: 520-2830; Vakit, 26 May1s 1336/1920, Nu: 899; Ikdam, 27 Mayis 1336/1920, Nu: 8364.

${ }^{69}$ Alemdar, 26 May1s 1336/1920, Nu: 520-2830; Vakit, 26 May1s 1336/1920, Nu: 899; Íkdam, 27 Mayis 1336/1920, Nu: 8364. 903.

${ }^{70}$ Takvim-i Vekâyi, 30 May1s 1336/1920, Nu: 3866; Vakit, 31 Mayıs 1336/1920, Nu:

${ }^{171}$ Takvim-i Vekâyi, 30 Mayıs 1336/1920, Nu: 3866. 
C) 1. Divân-ı Harbi Örfi Riyasetince Yargılanan Kuvâ-yı Milliye'nin Önde Gelen Simaları (17 Kişilik Liste)

Millî Mücadele Hareketi'nin gün geçtikçe gelişmesi ve Anadolu'da muktedir bir iktidar vücuda getirmesi, Damat Ferit Paşa ve Hükümeti'ni çileden çıkartmış, Kuvâ-yı Milliyecilerin Divân-1 Harbi Örfi'ler vasıtasıyla idam dahil birçok cezalara çarptırılma sürecini de hızlandırmıştır. 1. Divân-1 Harbi Örfi Riyaseti 30 Mayıs 1920'de muhakemeleri görülmek üzere 17 kişilik Kuvâ-yı Milliye Hareketi'nin önde gelen simalarını mahkemeye çağırmıştır. Mahkemeye çağrılan bu 17 kişilik liste şu isimlerden oluşmaktadır: 12. Kolordu Kumandanı İzmirli Fahreddin Bey bin İsmail, 3. Kolordu Kumandanı Asitaneli Hüseyin Selahaddin Bey bin Vehbi, 2. Kolordu Kumandanı Priştineli Cafer Tayyar Bey bin Emin, 14. Kolordu Kumandanı Mirliva Yozgatlı Yusuf İzzet Paşa bin İbrahim, Harbiye Nezâret-i Celilesi Esbak Müsteşarı Miralay İsmet, Yozgad Mebus-u Sabıkı İsmail Fazıl Paşa, Erzurum Mebus-u Sabıkı Celaleddin Arif Bey, Esbak Mebuslardan Hamdullah Subhi Bey ${ }^{172}$, Karacabey Müftü-i Sabıkı Mustafa Fehmi Efendi, Esbak Mebuslardan Cami Bey, Esbak Mebuslardan Bekir Sami Bey, Hakkı Behiç Bey, Sinop Mebus-u Sabıkı Rıza Nur Bey ${ }^{173}$, Kastamonu Mebus-u Sabıkı ve Adliye Müsteşar-1 Esbakı Yusuf Kemal Bey, Eskişehir Mutasarrıf-1 Esbakı Fatin Bey ${ }^{174}$, Ankara Müftü-i Sabıkı Mehmet Rifat Efendi ${ }^{175}$ ve Bursa'da Frrka Kumandanı Miralay Bekir Sami Bey ${ }^{176}$.

${ }^{172}$ Hamdullah Suphi Bey hakkında tafsilat için, Bkz. Enver Behnan Şapolyo, "Millî Mücadele'de Hamdullah Suphi”, Türk Kültürü̈, (Hamdullah Suphi Tanriöver Özel Sayıs1), Türk Kültürü Araştırma Enstitüsü, Sayı 45, Temmuz-1966, 799-801.

${ }^{173}$ Riza Nur Bey, o dönemi hatıratında şöyle anlatmaktadır: "Biz Hükümeti teşkil edince Padisah ve Ingilizler her ne yapabileceklerse yapmağa tesebbüs ettiler. Salih Pasa'yı atıp Ferit Paşa'yı Sadrazam yaptılar. Ferit Paşa Şeyhülislam Dürrizâde'nin imzastyla bir fetva neşrederek bunda bizi yani Heyet-i Vekile azasın huruc alessultan töhmetiyle itham edip, idamımıza karar verdiler. Hasılı idam cezasını yedik." İdam cezasının kendisi ve arkadaşları nezdinde bir tesir yapmadığını da şu cümlelerle izah etmektedir: "Şunu söyliyeyim ki, bana da bu yediğim idam cezası kuru sıkı bir tesir yaptı. Baktım idama mahkum olan arkadașlar da hiç müteessir görünmediler. Zaten ele geçersek bu idam cezasız da idam edileceğimiz muhakkak idi. Bunu da biliyorduk." Bkz. Rıza Nur, Hayat ve Hatıratım, Cilt: III, Yay. Haz. Heider Schmit, Altındağ Yayınevi, İstanbul-1967, s. 637.

${ }^{74}$ Eskişehir Mutasarrıfi Fatin Bey'in 20.3.1920 tarihinde Kastamonu valiliğine çektiği açık telgraf kendisi hakkında verilen idam kararında etkili olmuş olabilir. Fatin Bey'in Kastamonu Valiliği'ne çektiği telgraf şöyledir: “Ístanbul'un bașta Ingilizler olduğu halde düveli itilafiye tarafindan işgali ve milletvekillerinden birçoğunun caniyane bir suretle tevkifleri ve bir takım vesaiti hainane ile İslam hanelerinin taharrisi velhasil İslamlar hakkında bir medeniyet maskesi ile düveli mezkurenin irtikap eyledikleri fecayi ve mezalim bütün alemi islamı dilhun ve dağidar eylediği gibi bu tesirat bilhassa kurbiyeti dolaylsıyla Eskisehir livasında daha ziyade tecelli ederek her tarafta toplanan Kuvâ-yı Milliye galeyan ve heyecan ile meşbu olduklarl halde Anadolu Şarki ve garbi arasında benderi ticaret ve haizi ehemmiyet olan Eskişehir de bulunan 1000'e yakın İngiliz kuvvetlerini abluka ederek 24. Firka kumandanı muhterem Mahmut beyefendi ile müstereken Ingiliz kumandanina verdiğimiz ültimatomda milletin galeyan ve heyecanı tasvir ve kuvvetlerinin bu mübarek ve muazzez ve fedakar kuvvetler tarafindan abluka edilmiş olduğundan iki saate kadar 
Tabii olarak bu 17 kiși 1. Divân-1 Harbi Örfi Riyaseti'nin bu ilanını dikkate almamış ve mahkemede hazır bulunmamıştır. Gıyaben yapılan muhakemenin 6 Haziran 1920'de sonuçlanması ile bu 17 kișiden müteşekkil vatansever Kuvâ-yı Milliyeciler hakkında idam kararı alınmıştır ${ }^{177}$. Alınan bu idam kararında 11 Mayıs'ta Mustafa Kemal Paşa ve arkadaşları, 24. Mayıs'ta da Fevzi Paşa ile ilgili verilen kararlara dikkat çekilmiş ve bu 17 kişilik grubunda Mustafa Kemal Paşa, Fevzi Paşa ve arkadaşları ile işbirliği içerisinde oldukları dolayısıyla da Kuvâ-yı Milliye'nin elebaşı oldukları vurgulanmıştır. İdam kararında; bu 17 kişi meşrutiyetten beri birçok facianın sorumlusu olarak gösterilmektedir. Memleketin zor dönemlerinde "sıkıyı gör"düklerinde yabancı ülkelere firar eden ya da bir yerlere gizlenen, zemin ve zaman müsait olunca da ortaya çıkıp memleketi karıştırmayı kendilerine bir görev olarak kabul eden kişiler olarak tanımlanmaktadır. Bu 17 kişi, İttihat ve Terakki Cemiyeti'nin yârân ve müntesibi olarak anlatılmakta, Harbi Umumî'de açılan yaraların tamir edilmeye başlandığı bir dönemde, kurmuş oldukları cemiyetler vasıtasıyla İstanbul Hükümeti'nin devletin kurtulması yönünde almıș ve alacak olduğu önlemleri yok etmek için çaba harcadıkları ve milletin birlik ve bütünlüğünü bozdukları dile getirilmektedir. Yine idam kararında; bu 17 kişinin "Fetevâ-yı Şerife", "Hükümet Beyannamesi" ve "Hatt-l Hümayun"lar vasıtasılla giriştikleri yanlış yoldan dönmeleri hususunda uyarıldıkları fakat bunların "nedamet" duyup "Saltanat-ı Seniyye'nin cenah-ı adaletine iltica" edecelekleri yerde

memleketi terk ve İstanbul'a hareket etmedikleri takdirde dökülecek kandan mesul olacakları izah edilmesi üzerine ehali ve hükümetin kuvvei maneviyesini kırmak için her firsattan bilistifade nümayişler yapan bu haksız ve mütecaviz millet derhal memleketi terk edeceklerini ve ancak Izmit'e kadar yollarda düçarı tecavüz edilmemeleri esbabinın istikmalini rica eylemiş olduğundan o suretle müracaatlart kabul olunarak ihzar eyledikleri trenle hareket etmekte bulundukları binaenaleyh Eskişehir livası ehalisinin ve civardan gelen Kuvâyı muavenenin bu fedakarlı ve vatanperverliklerinin kariyyelere varincaya kadar neșir ve tefhim edilmesini bilhassa arz ve istirham eylerim. Eskişehir Mutasarrıfi Fatin." Kastamonu Valiliği'ne çekilen bu telgrafa Kastamonu Valisi aynı gün cevap vermiş ve șunları demiştir: "Eskişehir Mutasarrıflı̆̆ına. Fedakar ve muhterem ehalinizin gösterdiği azim ve metanetten ve Eskişehir'in sizin gibi hamiyetperver bir amire mazhariyetinden dolayı Kastamonu Vilayeti halkı namına kemali șükranla beyan takdirat ve tebrikat eylerim. Bu azim ve irade bizde mevcut oldukça bütün müskülata rağmen biavnillahi teala ibrazı zafer ve muvaffakiyet edeceğimize kanaatı umumiyemiz büyüktür. Dinini ve vatanın bir hubbü layemut ile seven bu milleti mükerremeye Cenabı Hakkın tevkifatını ihsan buyuracağına süphe yoktur. Bu vilavette de aynı azim ve niyetin layezal bir zeminde payidar olduğunu zikr etmekle kesbi fahr eder ve mazhariyeti mübeccelinizden naşi Livanız ve klymetli ehalinizi selamlarim efendim. Kastamonu Valisi Cemal." Bkz. Peker, 1918-1923 İstiklâl Savașı'nın Vesika ve Resimleri, s. $158-159$.

${ }^{75^{\circ}}$ Ankara Müftüsü Mehmet Rıfat Efendi'nin idam cezasına çarptırılmasında Mustafa Sabri'nin etkili olduğu muhtemeldir. Bkz. Sarıkoyuncu, "Şeyhülislam Mustafa Sabri'nin Tutumu...", s. 794.

${ }_{176}$ Vakit, 25 May1s 1336/1920, Nu: 898; İkdam, 25 May1s 1336/1920, Nu: 8362.

177 Alemdar, 25 Haziran 1336/1920, Nu: 549-2859; Peyam-ı Sabah, 25 Haziran 1336/1920, Nu: 566/10996; Vakit, 25 Haziran 1336/1920, Nu: 929. 
Hükümet ve Saltanat'a başkaldırdıkları, hatta bir ihtirasları neticesi olarak "eşhâs- $\iota$ şerîre"den müteşekkil bir Meclis topladıkları, Meclis'in vükelası sıfatıyla da bir hükümet ve idare teşkil ettikleri, bu suretle de Osmanlı Devleti'nin emniyet ve asayişini "hercümerç" ettikleri aktarılmaktadır ${ }^{178}$.

Devlet ve milletin hayat ve bekasına kast eden kişiler olarak görülen Kuvâ-yı Milliyecilerden Bekir Sami Bey'in Bursa'da, Karamürsel'de, Abbas Hilmi Bey'in de Geyve, Adapazarı ve Sapanca'da faaliyet gösteren "çeteler ${ }^{179}$ "in riyasetini yaptıkları, bu durumun ülkede asayişin yok edilmesine yönelik çalışmalar olduğu dikkatlere sunulmak istenmektedir. Ayrıca Yusuf Kemal Bey (İktisat Bakanı) ve Rıza Nur (Millî Eğitim Bakanı) Beylerin Ankara'ya katılmalarıyla birlikte çeşitli nazırlıklar elde ettikleri, Mustafa Fehmi Efendi'nin "o idare-i mel'unanenin şeyhülislamlığı" demek olan Umur-1 Şeriyye Vekaleti'ni (Din İşleri ve Vakıflar Bakanı) ve İsmet Paşa'nın da Erkan-1 Harbiye-i Umumiye Riyaseti'ni (Genelkurmay Başkanı) elde ettikleri, bu durumun da, bu kişilerin Mustafa Kemal Paşa'nın başlattığ 1 Millî Mücadele Hareketi'nin bilfiil içinde olduklarının delili olduğu anlatılmaktadır. Nihayetinde bu 17 kişilik grubun "suçları" sabit görülmüş ve 6 Haziran 1920'de Mülkiye Ceza Kanunname-i Hümayunu'nun 45. Maddesi'nin 1. F1kras1, 55. Maddesi'nin 4. F1kras1 ve 56. Maddesi mucibince asker olanların askerlik mesleğinden çıkartılmalarına, haiz oldukları bütün nişan ve madalyalarının alınmasına, firarda bulunmaları hasebiyle "cümlesinin mallarının haczettirilmesi"ne ve idamlarına karar verilmiştir ${ }^{180}$.

Kuvâ-yı Milliye'nin önde gelenlerinden olan bu 17 kişi hakkında 1 . Divân-1 Harbi Örfi tarafından 6 Haziran'da verilen yukarıdaki karar 15 Haziran 1920'de Padişah Sultan Vahdettin tarafından çıkarılan bir "İrade-i Seniyye" ile onaylanmış ve yürürlüğe girmiştir ${ }^{181}$. Bu "İrade-i Seniyye" sureti 21 Haziran'da Takvim-i Vekâyi'de yayınlanmışıır' ${ }^{182}$.

Millî Mücadele Hareketi'nin önde gelenleri hakkında verilen bu idam kararları ile Mustafa Kemal Paşa Başkanlığı'ndaki Büyük Millet Meclisi

178 Alemdar, 25 Haziran 1336/1920, Nu: 549-2859; Peyam-ı Sabah, 25 Haziran 1336/1920, Nu:566/10996; Vakit, 25 Haziran 1336/1920, Nu: 929.

79 1. Divân-1 Harbi Örfi Riyaseti'nce "çete" olarak tanımlandıkları için biz oradaki anlatıma uygun olarak tırnak işareti içerisinde "çete" tabirini kullanmayı uygun gördük. Millî Mücadele'nin düzensiz ordu dönemini kapsayan bu tür hareketler bizce "Milis Kuvveti" olarak tanımlanmaktadır: Doğrusu da "Milis Kuvveti" denmesidir.

180 Alemdar, 25 Haziran 1336/1920, Nu: 549-2859; Peyam-ı Sabah, 25 Haziran 1336/1920, Nu:566/10996; Vakit, 25 Haziran 1336/1920, Nu: 929.

${ }_{182}^{181} \boldsymbol{B O A}, \boldsymbol{B E O}$, Umumi No: 347778.

182 Takvim-i Vekayi, 21 Haziran 1336/1920, Nu: 3883; Alemdar, 22 Haziran 1336/1920; Nu: 549-2849; Peyam-ı Sabah, 22 Haziran 1336/1920; Nu: 563/10993; Vakit, 22 Haziran 1336/1920, Nu: 926. 
Hükümeti, 1. Divân-1 Harbi Örfi Riyaseti dolayısıyla da Damat Ferit Paşa Hükümeti tarafından idama mahkum edilmiştir: 1. Divân-1 Harbi Örfi'nin ilki 11 Mayıs, ikincisi 24 Mayıs ve üçüncüsü 6 Haziran'da olmak üzere vermiş olduğu kararlar neticesinde ilk Büyük Millet Meclisi Hükümeti üyeleri, başkanı Mustafa Kemal Paşa da dahil olmak üzere idama mahkum edilmiştir.

D) Divân-ı Harbi Örfilerce Yargılanan ve Çeşitti Cezalara Çarptırılan Diğer Kuvâ-yı Milliyeciler

Millî Mücadele Hareketi'ne çok değerli hizmetleri bulunan önemli bazı Kuvâ-yı Milliyeciler, Kuvâ-yı Milliye Hareketi'nin baş düşmanlarından olan Damat Ferit Paşa, Peyam-1 Sabah Gazetesi Başyazarı Ali Kemal ve İngiliz Muhibleri Cemiyeti'nin kurucusu Sait Molla'ya suikast girişiminde bulunmaktan yargılanmışlardır ${ }^{183}$. Suikast tertibinin başarılı olamaması neticesinde Dramalı Rıza ve Bahriye Yüzbaşısı Halil İbrahim Beyler tutuklanmışlardır ${ }^{184}$. Birçok Kuvâ-yı Milliyeci tutuklu, birçoğu da gıyaben olmak üzere Divân-1 Harbi Örfi'den yargılanmışlardır. Yargılama sonucunda; 56. Frrka Kumandanı Bandırmalı Bekir Sami, Karesi Mutasarrıflı̆̆ından Mütekait Uşaklı Hacim (Muhittin Çarıklı), Binbaşı Manastırlı Remzi, Bursa Polis Müdürü Nuri Efendi, Kayıkçı Ahmet, Dramalı Rıza Bey ${ }^{185}$, Bahriye Yüzbaşılarından Halil İbrahim, Asitaneli Tevfik, Üsküdar Belediyesi'nin Doğancılar Mevkii Memuru Asitaneli Mehmet Ali, Sahra Topçu Binbaşılığından Mütekait Üsküdarlı İhsan, Harbiye Dairesinde Binbaşı İsmail Hakkı, İstanbul Jandarma Taburu Kumandanlığından Mütekait Tolçalı Süleyman, Ziraat Bankası çalışanlarından Asitaneli Ahmet Halim Beyler, Şehremaneti Memurin-i Sabıkasından İbrahim Ağa, Bursa Yenişehirli Hasan, Bursalı Çoban İsmail, Muhafız İkinci Alayının Birinci Taburunun Üçüncü Bölüğünde Müstahdem Yüzbaşı Gelibolulu Bican Efendi, Dersaadet Jandarma Taburu Kumandanı Binbaşı Rizeli Raşid, Süvari Binbaşısı Asitaneli Adil ve Piyade Binbaşısı Cemal Bey'den asker olanların 9 Haziran tarihli mazbata-i hükmiyede muharrer olduğu üzere askerlikten tardlarıyla bunlardan Hacim, Mehmed,

183 Osman Akandere-Ferudun Ata, Dramalı Rıza Bey ve Millî Mücadeledeki Hizmetleri, Temel Yayınları, İstanbul-2008, s. 147; Suikastın görünürdeki sebebi, itilaf Devletleri ile sürdürülen sulh antlaşmasının yani Sevr'in imzasının önüne geçmekti. Bu suikastı gerçekleştirmek üzere Dramalı Rıza Bey, Bahriye Yüzbaşısı Halil İbrahim Bey ve kimlikleri hususunda açı bilgi bulunmayan Bursa Yenişehir'den Hasan ve Bursalı Çoban İsmail görevlendirilmiştir. Bkz. BOA, DUIT, Nu: 75/5-117.

${ }^{84} \boldsymbol{B O A}$, DUIT, Nu: 79/5-117; Dramalı Riza ve Halil İbrahim Beylerin vermiş oldukları ifadeler neticesinde pek çok kişi tutuklanmıştır. Bkz. BOA, DUIT, Nu: 79/5-117; Alemdar, 1 Haziran 1336/1920, Nu: 528/2828; Vakit, 1 Haziran 1336/1920, Nu: 904; Peyam-ı Sabah, 1 Haziran 1336/1920, Nu: 544/10974.

185 Dramalı Rıza Bey'in Millî Mücadele'deki yeri hakkında geniş bilgi için, Bkz. Akandere-Ata, Dramalı Riza Bey, s. 41-213. 
Nuri ve Remzi’nin mülkiye kanununa göre Halil İbrahim, Tevfik, Mehmet Ali, Binbaşı İhsan, İsmail Hakkı, Tolçalı Süleyman, Ahmet Halim, İbrahim Ağa, Hasan ve İsmail'in idamlarına, Adil, Raşid, Bican ve Cemal'in onar sene küreğe konulmasına karar verilmiștir ${ }^{186}$. Mahkeme, Dramalı Rıza Bey'in suikast tertibi suçundan muafiyetine, ancak Kuvâ-yı Milliye namı altında faaliyet gösteren "isyancılardan" olması ve "cinayet-i azimenin mürettip ve müşevviki" olması sebebiyle idamına karar verilmiştir ${ }^{187}$. Mahkeme'nin vermiş olduğu bu karar 11 Haziran 1920'de Padişah Sultan Vahdettin tarafindan tasdik edilmiş ve bununla ilgili "Irade-i Seniyye" 13 Haziran 1920'de Takvim-i Vekâyi'de yayınlanmıştır ${ }^{188}$. İdam kararı Padişah tarafından onaylanınca derhal uygulamaya geçilerek 12 Haziran'da tutuklu bulunan Dramalı Rıza, Halil İbrahim, Mehmet Ali ve Tevfik (Sükutî) Beyler idam edilmişlerdir ${ }^{189}$.

Bunlardan başka Kuvâ-yı Milliye taraftarı olduğu için Divân-1 Harbi Örfi Riyasetince çeşitli cezalara çarptırılan pek çok kişi mevcuttur: Mesela, Kartallı Hüseyin Avni bin Mehmet, Kuvâ-yı Milliye'ye iltihak için kıtasından firar ile Bursa'ya kaçmak suçundan askerlik mesleğinden çıkartılmak suretiyle gıyaben yedi sene küreğe mahkûm edilmiştir ${ }^{190}$. Kuvây1 İnzibatiye'nin içerisinde bulunup da Kuvâ-yı Milliye'ye iltihak etmek için firar eden Yüzbaşı Behzad Efendi bin Refik de altı ay hapse mahkûm edilmiş ve işkence görmüştür. Akabinde de bir yolunu bulup Anadolu'ya tekrar firar etmiştî ${ }^{191}$. Yine, birçok isim sırf Kuvâ-yı Milliye'ye mensup olmaları hasebiyle idama mahkûm edilmişlerdir ${ }^{192}$.

Bazı Kuvâ-yı Milliye efradı da dağlarda ve kırlarda silahlı olarak gezmek, rast geldikleri yolcuları soymak, dağa adam kaldırmak, ülkenin asayişi bozmak gibi suçlardan yargılanıp ağır hapis cezalarına

${ }^{186}$ BOA, DUIT, Nu: 79/5-117; Takvim-i Vekayi, 13 Haziran 1336/1920, Nu: 3878

187 BOA, DUIT, Nu: 79/5-117; Takvim-i Vekayi, 13 Haziran 1336/1920, Nu: 3878.

${ }^{188}$ Takvim-i Vekayi, 13 Haziran 1336/1920, Nu: 3878.

${ }^{189}$ Vakit, 13 Haziran 1336/1920, Nu: 917; Alemdar, 13 Haziran 1336/1920, Nu: 5402840

${ }_{190}$ Takvim-i Vekayi, 17 Temmuz 1336/1920, Nu: 3905.

191 TITE, Kutu No: 62, Belge No: 140; Bazı iltihaklar için, Bkz. TíTE, Kutu No: 62 , Belge No: 136.

Takvim-i Vekayi, 29 Temmuz 1336/1920, Nu: 3916; Takvim-i Vekayi, 1 Eylül 1336/1920, Nu: 3944; Mirliva Asitaneli Nurettin Paşa b. İbrahim Paşa, Mirliva Diyarbakırlı Kazım Paşa b. Hakkı, Kaymakam Taşköprülü Hüseyin Hüsnü Bey b. Abdullah, Miralay Bursalı Bahaeddin b. Seyyid Muhammed, Miralay Asitaneli Behiç Bey b. Cemil ve Erkan-1 Harbiye Kaymakamlarından Firuz Ağalı Seyfi Bey b. Rıza da Kuvấ-yı Milliye’ye iltihak suçundan giyaben idama mahkûm edilmişlerdir. Bkz. Alemdar, 17 Ağustos 1336/1920, Nu: 602-2902. 
çarptırılmışlardır ${ }^{193}$. Yine, Divân-1 Harb-i Örfî tarafından Kuvâ-yı Milliye’ye yardım ettiği gerekçesi ile de birçok kimse suçlu bulunmuş ve cezalandırılmıştır. Mesela Divân-1 Harb-i Örfî Eskişehirli Hacı Veli'yi Kuvâ-yı Milliye'ye yardım ettiği, Kuvâ-yı Milliye tarafından mebus seçildiği ve oğlunu Sivas Kongresi'ne göndermiş olduğu gerekçesi ile yedi sene küreğe mahkûm etmiştir ${ }^{194}$.

E) 1. Divân-ı Harbi Örfilerce Verilen Bu İdam Kararlarının Uygulanabilirliği

Millî Mücadele'nin önderleri ve Kuvâ-yı Milliye mensupları haklarında çıkarılan bu idam kararları Büyük Millet Meclisi'nde değerlendirilmiştir: Elaziz Mebusu Hüseyin Bey 15 Temmuz 1920'de, “Damat Ferit Hükümeti zamanında Dersaadet Divân-ı Harp Örfisinde verilen hükümlerin keenlemyekün addolunmasına dair" bir teklif vermiştir ${ }^{195}$. Meclis Reisi tarafından böyle bir teklif olduğunun okunması üzerine meclisteki milletvekilleri "zaten keenlemyekün"dür sesleriyle ${ }^{196}$ bu idam kararlarının zaten yok hükmünde olduğunu açıkça dile getirmişlerdir. Layiha Encümeni'ne gönderilen teklif değerlendirilmiş ve neticede "Dersaadette bulunan eşhas haklarında sadır olarak keenlemyekün addi lazımgelen hüküm ve mukarreratın âdemi tatbik ve infazına nasıl ki buraca imkânı maddî olmadĭ̆ gibi taşrada bulunan bu kabil mahkumin haklarındaki hükmün de bittabi kıymet ve mahalli takbik bulamayacağl derkardır. Binaenaleyh girişilen şu mücahadede hak ve hakikatin inşallah muvaffakiyetle tecelli ettiği takdirde Hükümeti mezkurenin değil cezaları, gayri muhik ve muvafik ittihaz edilmiş bilcümle muamelatı da bittabi hükümsüz kalacağına dair bir kanun kabul edildiği cihetle şimdilik şayan-ı dikkat olmayan mezkûr teklifin reddine" karar vermiştir ${ }^{197}$. Görüldüğü gibi Büyük Millet Meclisi Divân-1 Harbi Örfi'nin vermiş olduğu kararın yanında Damat Ferit Paşa dolayısıyla da İstanbul Hükümeti'ni de "keenlemyekün”

${ }^{193}$ BOA, BEO, Umumi No: 349174; BOA, DH. EUM. AYŞ. 38/43; Takvim-i Vekayi, 22 Eylül 1336/1920, Nu: 3962; Takvim-i Vekayi, 5 Teşrin-i Evvel (Ekim) 1336/1920, Nu: 3972. ; Takvim-i Vekayi, 11 Temmuz 1336/1920, Nu: 3900.

94 BOA, BEO, Umumi No: 348153; Takvim-i Vekayi, 17 Temmuz 1336/1920, Nu: 3905; Peyam-ı Sabah, 30 May1s 1336/1920, Nu: 542/10972; Kuvâ-y1 Milliyecilerin tutuklanmalarının istenmesi, tutuklamalar, Divân-1 Harplere sevkler, kararların padişah tarafından onaylanması vs. hakkında birkaç örnek: Bkz. BOA, $\boldsymbol{M V}, 221 / 164 ; \boldsymbol{B O A}, \boldsymbol{M V}$, 219/110; BOA, DH. EUM. AYS, 62/56; BOA, DH. EUM. AYS, 45/46; BOA, DH. EUM. $\boldsymbol{A Y S}, 44 / 90 ; \boldsymbol{B O} \boldsymbol{A}, \boldsymbol{B E O}$, Umumi No: 348629; BОA, BEO, Umumi No: 349076; ВОA, BEO, Umumi No: 348255.

${ }^{95}$ TBMM ZC, Devre: 1, İçtima Senesi: 1, Cilt: 1, 21. 7. 1336/1920, İ: 38, C: 1, 3. Bas1lis, TBMM Matbaas1, Ankara-1981, s. 370.

${ }_{996}$ TBMM ZC , Devre: 1, İçtima Senesi: 1, Cilt: 1, 21. 7. 1336/1920, İ: 38, C: 1, s. 370.

197 TBMM ZC, Devre: 1, İçtima Senesi: 1, Cilt: 3, 18. 8. 1336/1920, İ: 52, C: 1, 3. Bası1ış, TBMM Matbaası, Ankara-1981, s. 302. 
olarak addetmektedir. İstanbul Hükümeti'nin "keenlemyekün” olarak addedildiği bir durumda Divân-1 Harbi Örfi'nin verdiği kararın "keenlemyekün" olarak addedilmesinin bir ifadesinin olmayacağ 1 vurgulanmıştır. Ayrıca memleketin daha büyük ve önemli işlerinin olduğu, bu gibi önemsiz şeylerle uğraşılmaması gerektiği Nafiz Bey aracılığıyla dile getirilmiştir. Nafiz Bey konuşmasında "Meclisi Âli gayesine vasıl olduktan ve memleketi kurtardiktan sonra böyle şeyler mevzuubahis olabilir. Ĕger Meclis gayesine vasil olmazsa o zaman memleket maazallah bitmiştir",198 diyerek bu husustaki kati görüşünü dile getirmiştir.

Hakikaten de Millî Mücadele'nin önderleri hakkında verilen bu idam kararları, Mustafa Kemal Paşa'nın ülkenin kurtuluşu yönündeki çalışmalarına engel teşkil edecek bir mahiyet arz etmekten uzak kalmaktan öteye gidememiştir. Çünkü idam kararlarının çıktığı dönem itibariyle Mustafa Kemal Paşa yeni bir Devlet'in muştusu olan Büyük Millet Meclisi'ni açmış, "İcra Vekilleri Heyeti Reisi" sıfatıyla vatanın düşman işgalinden kurtulması için mücadelesine devam etmektedir. O dönem itibariyle Damat Ferit Paşa Hükümeti de, Divân-1 Harbi Örfi tarafından verilen gıyabî idam kararlarını uygulamaya koyamayacağının bilincindedir. Yukarıda da değinildiği gibi Damat Ferit Paşa tarafından çıkartılan bu idam kararları uygulanabilirlik noktasında olmadığı için "keenlemyekün" yani yok hükmünde olmaktan öteye geçememiştir. Çünkü Anadolu'nun kontrolü Büyük Millet Meclisi'nin elindedir, dolayısıyla da Anadolu'da İstanbul Hükümeti'nin otoritesi mevcut değildir. Damat Ferit Paşa Hükümeti'nin böylesi idam kararları çıkartmasındaki temel maksat; İngilizleri mutlu, kendilerini de teselli etmekten başka bir şey değildir. Damat Ferit Paşa Hükümeti'nin idam kararlarını çıkarttırmasındaki temel düşüncesi; "İttihatçılık"la, "Bolşeviklik"le itham ettikleri, "Fetvâ-yı Şerife" çıkartmak suretiyle öldürülmelerinin farz olduğunu ilan ettikleri, hatta "Kuvâ-yı Inzibatiye" teşkil etmek suretiyle tenkil etmeyi umdukları fakat hiç birisinde başarılı olamadıkları Mustafa Kemal Paşa ve arkadaşlarını, bu defa da hukukî olarak hükümlü haline sokmak ve "şirin" gözükmeyi şiar edindikleri İngilizlere "biz elimizden gelen herşeyi yapma yolunda azimliyiz, fakat ne

198 Abdulkadir Kemali Bey'in (Kastamonu) asılanlar ne olacak? "İzahat versinler" hususundaki sualine Nafiz Bey (Canik) söz almıș ve "Efendim, İstanbul'da bir Hükümetin mevcut olmadiğı Meclis-i Âlice kabul edilmisti. Simdiye kadar cereyan eden müzakerat bu esasa müptenidir. Binaenaleyh İstanbul'da Hükümet taslağı bulunan Damat Ferit'in teşkil ettiği bir Divanı harbin verdiği hüküm de tabiativle keenlemvekündür. Bunu Meclisi Âlide mezuubahis etmeye mahal yoktur. Meclisi Âli gayesine vasil olduktan ve memleketi kurtardıktan sonra böyle şeyler mevzuubahis olabilir. Eğer Meclis gayesine vasıl olmazsa o zaman memleket maazallah bitmiștir. Binaenaleyh reddini talep ediyorum. (Müzakere kâfi sadalarl)." Demiştir. Bkz. TBMM ZC, Devre: 1, İçtima Senesi: 1, Cilt: 3, 18. 8. 1336/1920, İ: 52, C: 1,3 , s. 302. 
yapsak başarılı olamıyoruz" deme hakkına sahip olmaktır. Dönem itibariyle de Milli Mücadele'ye karşı tutumuna baktığımızda "elimden geleni yapıyorum" deme hakkına da sahip olduğu rahatlıkla söylenebilir.

Damat Ferit Paşa Hükümeti haricinde hiçbir İstanbul Hükümeti Mustafa Kemal Paşa ve arkadaşları yani Millî Mücadele Hareketi ile ciddî bir sürtüşme içerisine girmemiştir. Nitekim Damat Ferit Paşa'dan sonra Hükümet'e gelen Tevfik Paşa, Damat Ferit Paşa'nın Kuvâ-yı Milliye'ye yönelik girişimleri sonucunda ortaya çıkan durumu düzeltmek için çaba sarf etmiştir. Damat Ferit Paşa, "Hükümet Beyannamesi" ve "Fetvâ-yı Şerife" ile Kuvâ-yı Milliye Hareketi'nin "isyancılardan" müteşekkil bir grup olup öldürülmelerinin farz olduğunu ilan etmişti. Yukarıda detaylıca incelediğimiz bu "Fetvâ-yı Şerife" ve "Hükümet Beyannamesi”"nin ardından da Kuvâ-yı Milliyecileri Divân-1 Harbi Örfi'de yargılatmak suretiyle idam cezasına çarptırmıştı. Tevfik Paşa iktidara gelince, bu belirtmiş olduğumuz olumsuz durumun önüne geçmek ve Kuvâ-yı Milliye ile tekrar bağlantı kurmak için girişimlerde bulunmuştur. Öncelikle Kuvâ-yı Milliye Hareketi'ne bakış değişmiştir: Önceden "Kuvâ-yı Băgiye”, "Kuvâ-yı Gayr-ı Milliye" vb. ithamlara maruz kalan Kuvâ-yı Milliye Hareketi bu dönemde İstanbul Hükümeti tarafindan da vatanın kurtuluşu için mücadele eden kuvvetler olarak kabul edilmiştir. Harbiye Nazırı Ziyaeddin imzalı bir belgede Kuvâ-yı Milliye Hareketi; "vatanın savunulması için teşsekkül etmiş bir kuvvet" olarak tanımlanmaktadır. "Düşman tecavüzlerine karşl vatan ve milletin namusunu kahramanca savunma ve koruma ile meşgul bulun"dukları da ayrıca vurgulanmaktadır. Ziyaeddin Paşa, Kuvâ-yı Milliye mensupları haklarında daha önceden verilen kararların kesinlikle adaletle bağdaşmayacağını, o kararların aksine Kuvâ-yı Milliye Hareketi'nin alkışlanmaya değer ve tebrike şayan işler yaptığını belirtmiştir. Kuvâ-yı Milliyeciler hakkındaki kovuşturmaların kaldırılmasını da istemiştir ${ }^{199}$. Neticede Divân-1 Harbi Örfi Heyeti, 7 Mayıs 1921 tarihinde "vatanin savunulması gibi çok saygıya değer bir hadiseyle çelişmekte olan bu durumun (Kuvâ-yı Milliye aleyhindeki kararlar kastediliyor) kaldırlmasını kutsal vatanımızın selameti ve esas vazifemiz itibariyle çok gerekli görmekte olduğumuzu ve bu töhmetlere dayanarak mallarının üzerine konulmuş olan haczin kaldırılmasını da eshabının aileleri için açık bir hak" olarak gördükleri yönünde bir karar almıştır ${ }^{200}$.

Görüldüğü gibi Damat Ferit Paşa Hükümeti'nden sonra gelen Tevfik Paşa Hükümeti Dönemi'nde Kuvâ-yı Milliye Hareketi'ne İstanbul'un bakışı

${ }^{199}$ Hamdi Atamer, "Millî Mücadele’ye Katılanlar Hakkında Askerî Yargıtay Kararları”, Belgelerle Türk Tarihi Dergisi, Sayı: 3, İstanbul-1967, s. 5.

${ }^{200}$ Atamer, "Askerî Yargitay Kararlart", s. 6. 
tamamen değişmiştir. Tevfik Paşa Hükümeti, Kuvâ-yı Milliye Hareketi'ni, "vatanın müdafaası adına teşkil edilmiş bir hareket" olarak algılamış ve iyi ilişkiler kurma yönünde gayret göstermiştir.

\section{SONUÇ}

Damat Ferit Paşa, IV. Sadareti öncesinde "Itttihatçılık", "Bolşeviklik", "Yalancı Milliyetçilik"le itham ettiği Kuvâ-yı Milliyecileri, IV. Sadaretinde "Hükümetin Beyannamesi", "Padişahın Hatt-ı Hümayunu" ve Şeyhülislam Dürrizâde Abdullah Efendi'ye çıkartmış olduğu "Fetvâ-yı Şerife" aracılığıyla etkisiz hale getirmeye çalışmıştır. Özellikle Dürrizâde'nin çıkardığı Fetvâ-yı Şerife aracılığıyla Mustafa Kemal Paşa ve arkadaşları; "dinsizlik", "devlete ve millete düşmanlık"la suçlanmış, nihayetinde de öldürülmelerinin "farz" olduğu Anadolu insanına duyurulmuştur. Böylelikle halkın dinî duyguları siyasî hesaplar uğruna kullanılmaya çalışılmıştır.

Damat Ferit Paşa, Kuvâ-yı Milliye Hareketi'ni tenkil etmek maksadıyla bir de Kuvâ-yı İnzibatiye adını verdiği birlikler vücuda getirmiştir. İngilizler tarafindan da desteklenen bu birlikler sayesinde Kuvâ-yı Milliye'nin ortadan kaldırılmasını sağlamaya çalışmış fakat başarılı olamamıştır. Nihayetinde bütün çabalarına rağmen üstesinden gelemediği Kuvâ-yı Milliye Hareketi'ni bu sefer hukukî yönden mahkûm etme yolunda çalışmalara girişmiştir: Öncelikle 1. Divân-1 Harbi Örfi'nin başına Nemrut Mustafa Paşa'yı getirmiştir. Nemrut Mustafa Paşa'nın başkanlık ettiğgi 1. Divân-1 Harbi Örfi, Mustafa Kemal Paşa ve yakın arkadaşları başta olmak üzere pek çok Kuvây1 Milliye mensubunu, memleketin kurtuluşu için mücadele etmek "suçundan" yargılayıp idam dâhil olmak üzere çeşitli cezalara çarptırmıştır: İlk olarak Mustafa Kemal Paşa ve arkadaşları gıyaben yargılanmışlar ve "Mülkiye Ceza Kanunname-i Hümayunu" gereğince (24 Mayıs) "idamlarına" karar verilmiştir. Ardından Fevzi Paşa (27 Mayıs), onun ardından da aralarında İsmet Bey, Rıza Nur ve Hamdullah Suphi gibi önemli simalarında bulunduğu 17 kişi yargılanmış ve (15 Haziran) "idama" mahkûm edilmiş̧lerdir. Böylelikle Büyük Millet Meclisi’nin ilk İcra Vekilleri Heyeti üyeleri, başkanı Mustafa Kemal Paşa da dâhil olmak üzere 1. Divân-1 harbi Örfi Riyaseti, nihayetinde de Sultan Vahdettin tarafindan idama mahkûm edilmiştir. Bu mahkûmiyet neticesinde de "idama mahkûm edilmiş bir Hükümet" ile karşı karşıya kalınmıştır.

Damat Ferit Paşa'ya göre memleketin kurtuluşu için işgallere sessiz kalınması, "büyük devletlerle" iyi ilişkiler içerisinde olunması gerekmektedir. Mustafa Kemal Paşa ve arkadaşları da, bu "iyi ilişskiler kurma" yolunda büyük bir engel olarak görülmektedir. Fakat bağımsızlığa gölge düşüren bu işgallere sessiz kalmayıp bilfiil mücadeleye girişmeyi 
gerekli gören ve canların feda edilmesi neticesinde de olsa, işgalci kuvvetlerin değil Anadolu'nun iradesine göre, "millî iradeye müstenit" bağımsız bir hayat sürmek isteyen Mustafa Kemal Paşa ve arkadaşları, Damat Ferit Paşa'nın bütün engellemelerine rağmen azimle mücadelelerine devam etmişler ve nihayetinde de "tam bağımsız" bir Türkiye Cumhuriyeti Devleti'ni kurmayı başarmışlardır.

\section{KAYNAKÇA}

Arşivler

Ankara Üniversitesi Türk İnkılâp Tarihi Enstitüsü Arşivi (TITTE)

Başbakanlık Osmanlı Arşivi (BOA)

\section{Gazeteler,}

Alemdar

Hâkimiyet-i Milliye

Ikdam

Peyam

Peyam-ı Sabah

Takvim-i Vekayi

Vakit

Dergiler ve Zabut Cerideleri

Askerî Tarih Belgeleri Dergisi (ATBD)

Harp Tarihi Vesikaları Dergisi (HTVD)

TBMM ZC, Devre I, İçtima Senesi I, Cilt: 1, 3. Basııış, TBMM Matbaası, Ankara1959.

TBMM ZC, Devre: 1, İçtima Senesi: 1, Cilt: 1, 21. 7. 1336/1920, İ: 38, C: 1, 3. Basılış, TBMM Matbaası, Ankara-1981.

TBMM ZC, Devre: 1, İçtima Senesi: 1, Cilt: 3, 18. 8. 1336/1920, İ: 52, C: 1, 3. Basılış, TBMM Matbaası, Ankara-1981.

\section{Kitaplar}

ADIVAR, Halide Edip, Türk'ün Ateşle Imtihanı, 11. Basım, Atlas Kitabevi, İstanbul-1994. 
AKANDERE-Osman Ferudun Ata, Dramalı Rıza Bey ve Millî Mücadeledeki Hizmetleri, Temel Yayınları, İstanbul-2008.

AKÇAM, Taner, Insan Hakları ve Ermeni Sorunu (Ittihat Terakki’den Kurtuluş Savaşı'na), İmge Kitabevi Yayınları, İstanbul-1999.

AKŞİN, Sina, İstanbul Hükümetleri ve Millî Mücadele -Mutlakıyete Dönüş (1918-1919)-, Cilt: 1, Türkiye İş Bankası Kültür Yayınları, Ankara-1998.

ATA, Ferudun, İsgal İstanbul'unda Tehcir Yargılamaları, Türk Tarih Kurumu Basımevi, Ankara-2005.

ATA, Feridun, Bir İşbirlikçinin Portresi Nemrut Mustafa Paşa, Temel Yay., İstanbul 2008.

ATATÜRK, M. Kemal, Nutuk, Cilt: III, (1917-1927), Belgeler, Yay. Haz. İsmet Gönülal, Ankara-1984.

ATATÜRK, M. Kemal Nutuk (1919-1927), Yayına Hazırlayan: Zeynep Korkmaz, Atatürk Araştırma Merkezi Yayınları, Ankara-2005.

Atatürk ile Ilgili Arşiv Belgeleri (1911-1921 Tarihleri Arasına Ait 106 Belge), Başbakanlık Osmanlı Arşivi Daire Başkanlığ Yayını, Ankara-1982.

Atatürk’ün Söylev ve Demeçleri I-III, Cilt: 1, Atatürk Araştırma Merkezi Yayınları, Ankara-1997.

Atatürk'ün Tamim, Telgraf ve Beyannameleri IV, Türk Tarih Kurumu Basımevi, Ankara 1991.

BARDAKÇI, Murat, Şahbaba (Osmanoğullarının Son Hükümdarı VI. Mehmed Vahideddin'in Hayatı, Hatıraları, Özel Mektuplart), Pan Yayınları, 1. Baskı, İstanbul-1988.

BEYATLI, Yahya Kemal Siyasî ve Edebi Portreler, Baha Matbaası, İstanbul-1968.

BIYIKOĞLU, Tevfik, Atatürk Anadolu’da I, Türkiye İş Bankası Kültür Yayınları, Ankara 1959.

BIYIKOĞLU, Tevfik, Trakya'da Millî Mücadele, Cilt: II, 2. Bask1, Türk Tarih Kurumu Basımevi, Ankara-1987.

CEBESOY, Ali Fuat, Millî Mücadele Hatıraları, Temel Yayınları, İstanbul-2000.

DANIŞMAN, H. Basri, Artçı Diplomat-Son Osmanlı Hariciye Nazırlarından Mustafa Reşit Paşa, Arba Yayınları, İstanbul-1998.

DANIŞMEND, İsmail Hami, İzahlı Osmanlı Tarihi Kronolojisi, Cilt: IV, İstanbul1972.

DÖNMEZ, Cengiz, Millî Mücadele’ye Karşı Bir Cemiyet, Ingiliz Muhibleri Cemiyeti, Atatürk Araştırma Merkezi Yayınları, Ankara-1999. 
ESENGIN, Kenan, Millî Mücadele'de Ayaklanmalar, III. Basım, Kamer Yayınları, İstanbul-1998.

EZHERLİ, İhsan, Türkiye Büyük Millet Meclisi (1920-1998) ve Osmanlt Meclis-i Mebusanı (1887-1920), 2. Baskı, TBMM Kültür, Sanat ve Yayın Kurulu Yayınlar1, Ankara-1998.

GÖK, Hayrullah, Mareşal Fevzi Çakmak'ın Askerî ve Siyasî Faaliyetleri (18761950), Genelkurmay Basımevi, Ankara-1997.

Imparatorluktan Cumhuriyete (Fahrettin Altay Paşa Anlattyor), Yayına Hazırlayan: Taylan Sorgun, II. Basım, Kamer Yayınları, İstanbul 1998.

İNAL, İbnülemin Mahmut Kemal, Son Sadrazamlar, Cilt: 4, 3. Baskı, Dergâh Yayınları, İstanbul-1982.

JAESCHKE, Gotthard, Kurtuluş Savaşı Ile Ilgili Ingiliz Belgeleri, Türkçeye Çeviren: Cemal Köprülü, Türk Tarih Kurumu Basımevi, Ankara-1971.

JAESCHKE, Gotthard, Türk Kurtuluş Savaşı Kronolojisi, 2. Baskı, Türk Tarih Kurumu Basımevi, Ankara-1989.

KADRİ, Hüseyin Kazım, Meşrutiyetten Cumhuriyet'e Hatıralarım, Haz. İsmail Kara, İletişim Yayınları, İstanbul-1991.

KANSU, M. Müfit, Erzurum'dan Ölümüne Kadar Atatürk’le Beraber, Cilt: 1, Türk Tarih Kurumu Basımevi, Ankara-1986.

KARABEKİR, Kazım, İstiklal Harbimiz, Cilt: 1, Emre Yayınları, İstanbul-1995.

KARAY, Refik Halid Minelbab İlelmihrab (Mütareke Devri Anıları), 2. Bask1, İnk1lâp Kitabevi, İstanbul-1992.

Mehmet Arif Bey, Anadolu Ínkılâbı Millî Mücadele Anıları (1919-23), Yayına Hazırlayan: Bülent Demirbaş, İkinci Basım, Arba Yayınları, İstanbul-1992

Mehmet Tevfik Bey'in (Biren) Abdülhamit, Meşrutiyet ve Mütareke Devri Hatıraları, Yayına Hazırlayan: F. Rezan Hürmen, Cilt II, Arma Yayınları, İstanbul-1993.

Mevlanzade Rıfat, Ittihat Terakki İktidarı ve Türkiye İnkılâbının İç Yüzü, Yedi İklim Yayınları, İstanbul-1993

Miralay Bekir Sami Günsav'ın Kurtuluş Savaşı Anıları, Hazırlayan: Muhittin Ünal, Cem Yayınları, II. Basım, İstanbul-2002.

NUR, Rıza, Hayat ve Hatıratım, Cilt: III, Yay. Haz. Heider Schmit, Altındağ Yayınevi, İstanbul-1967.

OKDAY, Şefik, Büyükbabam Son Sadrazam Ahmet Tevfik Paşa, İstanbul-1986. 
ÖZKAN, Hülya, İstanbul Hükümetleri Karşıtı Faaliyetleri (4 Mart 1919-16 Ekim 1920), Genelkurmay Basımevi, Ankara-1994.

ÖZSOY, Osman Saltanat'tan Cumhuriyet'e Giden Yolda Kurtuluş Savaşı'nın Perde Arkası, Aksoy Yayıncılık, İstanbul-1999.

PEKER, Nureddin, 1918-1923 İstiklâl Savaşı'nın Vesika ve Resimleri (İneboluKastamonu ve Havalisi Deniz ve Kara Harekâtt), İstanbul-1955

REY, Ahmet Reşit, Canlı Tarihler, Gördüklerim Yaptıklarım, İstanbul-1945.

SARIHAN, Zeki, Kurtuluş Savaşı Günlü̆ğü, Cilt: II, Türk Tarih Kurumu Basımevi, Ankara-1994.

SARIKOYUNCU, Ali, Millî Mücadele'de Din Adamları, Cilt: 1, Diyanet İşleri Başkanlığı Yayınları, Ankara-1995.

SOFUOĞLU, Adnan, Kuvâ-yı Milliye Döneminde Kuzeybatı Anadolu(1919-1921), Genelkurmay Basımevi, Ankara-1994.

SONYEL, Salahi R, Kurtuluş Savaşı ve Dış Politika, Cilt: I, 2. Baskı, Türk Tarih Kurumu Basımevi, Ankara-1987.

SONYEL, Salahi R, Kurtuluş Savaşı Günlerinde İngiliz İstihbarat Servisi'nin Türkiye'deki Eylemleri, Türk Tarih Kurumu Basımevi, Ankara 1995.

SÖYLEMEZOĞLU, Galip Kemalî, 30 Senelik Siyasî Hattralarım (Üçüncü ve Son Cilt) 1918-1922, Ülkü Matbaası, İstanbul-1953.

SÖYLEMEZOĞLU, Galip Kemali, Başımıza Gelenler (Yakın Bir Mazinin Hatıralart), Kanaat Kitabevi, İstanbul-1939.

ŞIMŞSiR, Bilâl N,. Ingiliz Belgelerinde Atatürk, Cilt: 2, Türk Tarih Kurumu Basımevi, Ankara-1975.

ŞİMŞİR, Bilâl N,. Malta Sürgünleri, İstanbul-1976.

TANSEL, Selahattin, Mondros'tan Mudanya'ya Kadar, Cilt: 1, Milli Eğitim Bakanlığı Yay., İstanbul 1991.

TANSU, Samih Nafiz, İki Devrin Perde Arkası, Anlatan: Hüsamettin Ertürk, Sebil Yayınları, İstanbul-1996.

TEMEL, Mehmet İsgal Yillarında İstanbul'un Sosyal Durumu, Kültür Bakanlı̆ğ Yayınları, Ankara-1998.

TEPEYRAN, Ebubekir, Hazım, Belgelerle Kurtuluş Savaşı Anıları, Çağdaş Yayınları, İstanbul-1982.

TUNAYA, Tarık Zafer, Türkiye'de Siyasal Partiler, Cilt. III, Hürriyet Vakfı Yayınları, İstanbul-1989. 
Türk İstiklal Harbi -íç Ayaklanmalar (1919-1921)-, Cilt: VI, Genelkurmay Basımevi, Ankara-1964.

Türk İstiklâl Harbi, İstiklâl Harbinde Ayaklanmalar, Cilt: IV, Genelkurmay Harp Tarihi Başkanlığı Yayınları, Ankara-1974.

TÜRKGELDİ, Ali Fuat, Görüp İşittiklerim, Türk Tarih Kurumu Basımevi, Ankara1949.

TÜRKMEN, Zekeriya, Mütareke Döneminde Ordunun Durumu ve Yeniden Yapılanması (1918-1920), Türk Tarih Kurumu Basımevi, Ankara-2001.

TÜRKMEN, Zekeriya, Yeni Devletin Şafağında Mustafa Kemal (Ekim 1918-Ocak 1920), Atatürk Araştırma Merkezi Yayınları, Ankara-2002.

URAN, Hilmi, Hattralarım, Ankara-1959.

YALÇIN, E. Semih - Koca, Salim, Mustafa Kemal Paşa'nın Anadolu'ya Geçişi, Berikan Yayınevi, Ankara-2005.

YALMAN, Ahmet Emin, Yakın Tarihte Gördüklerim ve Geçirdiklerim I, Yayına Hazırlayan: Erol Sadi Erdinç, İstanbul-1997.

ZÜRCHER, Eric Jan, Milli Mücadele'de İttihatçılık, İletişim Yayınları, İst-2003.

Tezler

ERDEM, Ş. Can, Sadrazam Damat Ferit Paşa, Marmara Üniversitesi, Türkiyat Araştırmaları Enstitüsü, Yayınlanmamış Doktora Tezi, İstanbul-2002.

Makaleler

AKANDERE, Osman, "11 Nisan 1920 (1336) Tarihli Takvim-i Vekâyi’de Kuvâ-y1 Milliye Aleyhinde Yayınlanan Kararlar", Ankara Üniversitesi Türk İnkılâp Tarihi Enstitüsü Atatürk Yolu Dergisi, Y11: 12, Say1: 24, Ankara-2003.

AKÇAM, Taner, "Divan-1 Harbi Örfi'lerin Kurulması-İstanbul Yargılamaları", Tarih ve Toplum, Say1: 137, (May1s 1995).

ARSLAN, Ali, "Anadolu Fevkalade Müfettişi Umumiliği", Ankara Üniversitesi Türk İnkllâp Tarihi Enstitüsü Atatürk Yolu Dergisi, Cilt: 4, Sayı: 16, Kasım, Ankara-1995.

ATAMER, Hamdi, "Kuvâ-yı Milliye'ye Katılanların Listesi”, Belgelerle Türk Tarihi Dergisi, Sayı: 4, Ocak-1968.

ATAMER, Hamdi, "Kuvâ-yı Milliye'ye Katılanların Listesi”, Belgelerle Türk Tarihi Dergisi, Sayı: 5, Şubat-1968.

ATAMER, Hamdi, "Kuvâ-yı Milliye'ye Katılanların Listesi”, Belgelerle Türk Tarihi Dergisi, Sayı: 6, Mart-1968. 
ATAMER, Hamdi, “Kuvâ-yı Milliye'ye Katılanların Listesi”, Belgelerle Türk Tarihi Dergisi, Say1: 7, Nisan-1968.

ATAMER, Hamdi, “Kuvâ-yı Milliye'ye Katılanların Listesi”, Belgelerle Türk Tarihi Dergisi, Sayı: 8, Mayıs-1968.

ATAMER, Hamdi, “Millî Mücadele'ye Katılanlar Hakkında Askerî Yargıtay Kararları”, Belgelerle Türk Tarihi Dergisi, Sayı: 3, İstanbul-1967

AYIŞIĞI, Metin, "Bir Askeri Mahkeme: İstanbul Birinci Divan-1 Harbi Örfîsi" Yedinci Askeri Tarih Semineri Bildirileri I, Ankara-2000.

ÇAĞLAR, Günay, "Kuvây-1 İnzibâtiye", Ankara Üniversitesi Türk Inkılâp tarihi Enstitüsü Atatürk Yolu Dergisi, Sayı: 4, 15 Mayıs 1995.

ÇAĞLAR, Günay, "Millî Mücadele'de Fetvalar Olayına Değişik Bir Açıdan Bakıș”, Atatürk Üniversitesi Türkiyat Araştırmaları Enstitüsü Dergisi, 75. Yıl Özel Sayı1, Sayı: 11, Erzurum-1999.

JAESCHKE, Gotthard, "Milliyetçiliğin ve Dinin İstiklal Harbindeki Rolleri”, Türk Dünyası Araştırmaları Dergisi, Sayı: 13, (Ağustos), Ankara-1981.

KISIKLI, Emine, “Millî Mücadele Başlangıcında, Mustafa Kemal Paşa'nın Millî Hareketi, İttihat ve Terakki Faaliyetlerinde Uzak Tutma Teşebbüsleri”, Ankara Üniversitesi Türk İnklâp Tarihi Enstitüsü Atatürk Yolu Dergisi, Y1l: 3, Say1: 5, Ankara-1990.

KÜÇÜK, Cevdet, “Damat Ferit Paşa”, İslam Ansiklopedisi, Diyanet Vakfı Yayınları, Cilt: 8, İstanbul-1993.

SARIKOYUNCU, Ali, “Şeyhülislam Mustafa Sabri’nin Millî Mücadele ve Atatürk İnkılâpları Karşıtı Tutum ve Davranışları”, Atatürk Araştırma Merkezi Dergisi, Cilt: XIII, Say1: 39, Kasım-1997.

SERTOĞLU, Midhat, “Millî Mücadele’ye Yardım Ettikleri İçin Cezalandırılmak İstenenlere Dair Yayınlanmamış Belgeler”, Hayat Tarih Mecmuası, Yıl: 14, Sayı: 2, Şubat-1978.

SERTOĞLU, Mithat, “ Son Osmanlı Padişahı VI. Mehmet Vahideddin ”, Hayat Tarih Mecmuası, Y1l:11, Cilt: 2, Sayı: 7, (1 Temmuz 1975).

ŞAPOLYO, Enver Behnan, “Millî Mücadele'de Hamdullah Suphi”, Türk Kültürü̈, (Hamdullah Suphi Tanrı̈̈ver Özel Sayısı), Türk Kültürü Araştırma Enstitüsü, Sayı 45, Temmuz-1966. 
TEVETOĞLU, Fethi, "Atatürk-İttihat ve Terakki”, Atatürk Araştırma Merkezi Dergisi, Cilt: V, Say1: 15, Temmuz-1989.

TÜRKMEN, Zekeriya, "Kuvâ-y1 Millîye Hareketini Bastırmak Üzere İstanbul Hükümetinin Kurduğu Bir Teşkilât: Anadolu Fevkalâde Müfettişi Umumiliği", Türk Tarihçiliği ve Prof. Dr. Aydın Taneri Armağanı, Ankara-1998. 


\section{EKLER}

EK-1

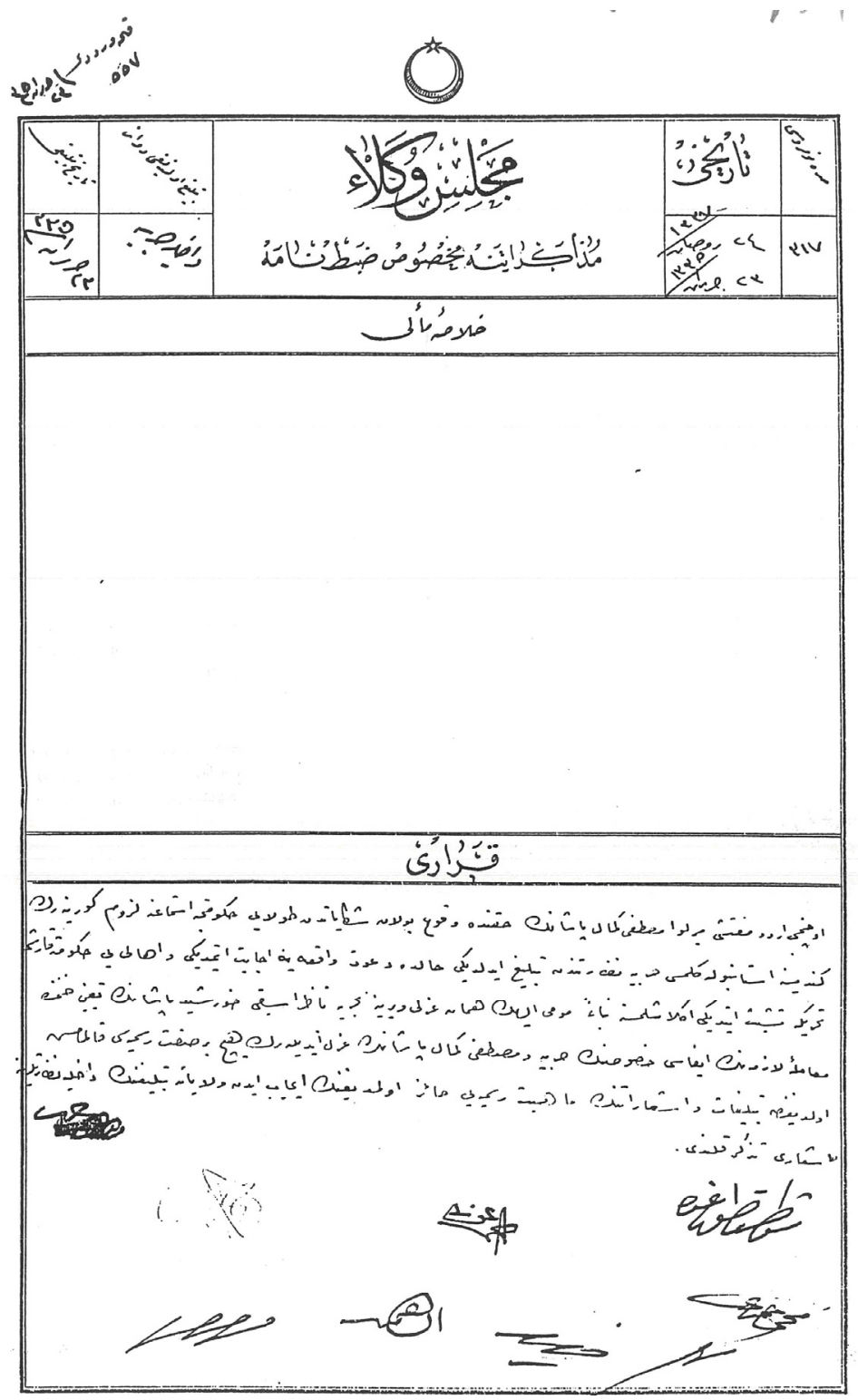

BOA, MV, 216/54

Mustafa Kemal Paşa'nın azledilerek yerine Bahriye Nazırı Hurşit Paşa'nın tayini hakkında Meclis-i Vükela kararı. 
EK-2

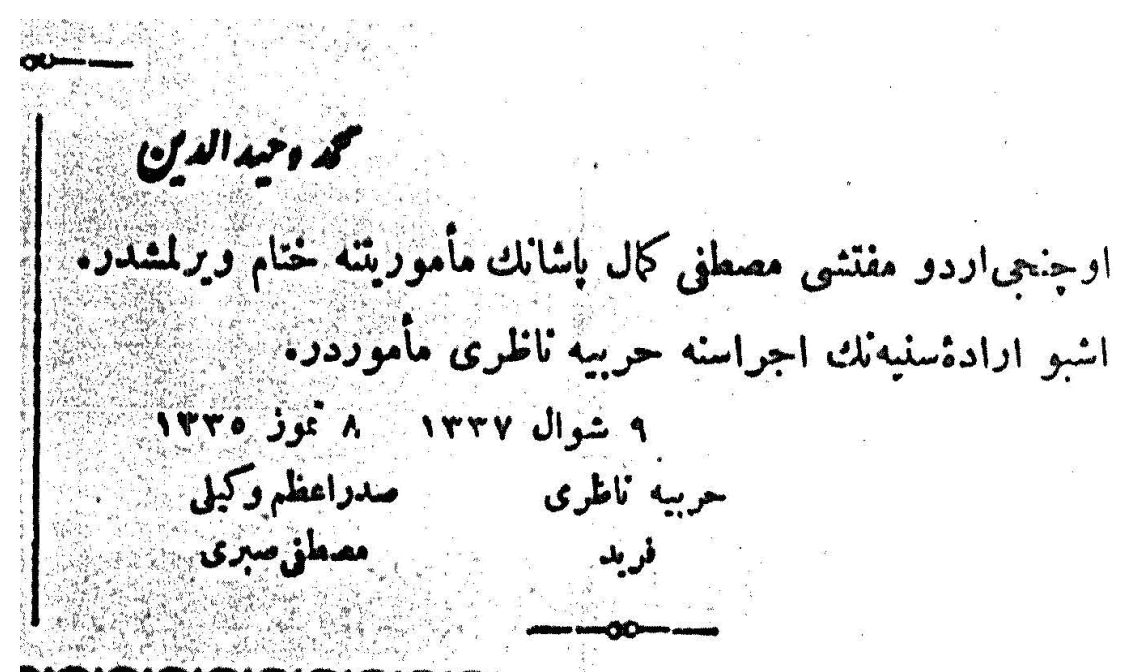

Takvim-i Vekayi, 13 Temmuz 1335/1919, Nr: 3596.

Mustafa Kemal Paşa'nın Üçüncü Ordu Müfettişliği'nden azledildiğine dair Takvim-i Vekâyi'de yayınlanan İrade-i Seniyye sureti. 
EK-3

إد'

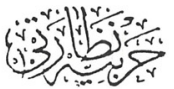

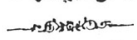

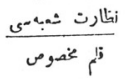

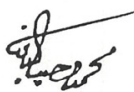

IIए.

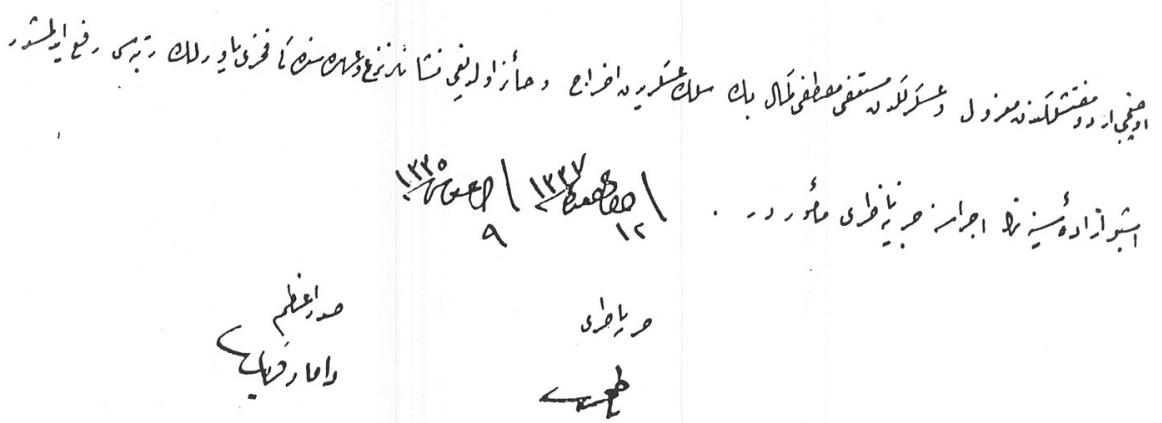

BOA, DUIT, 68/13

Mustafa Kemal Paşa'nın askerlik mesleğinden azli, nişan ve madalyaları ile fahri yaverlik rütbesinin de kaldırılması hakkında 9 A ğustos 1335/1919 tarihli İrade-i

Seniyye. 


\section{EK-4}

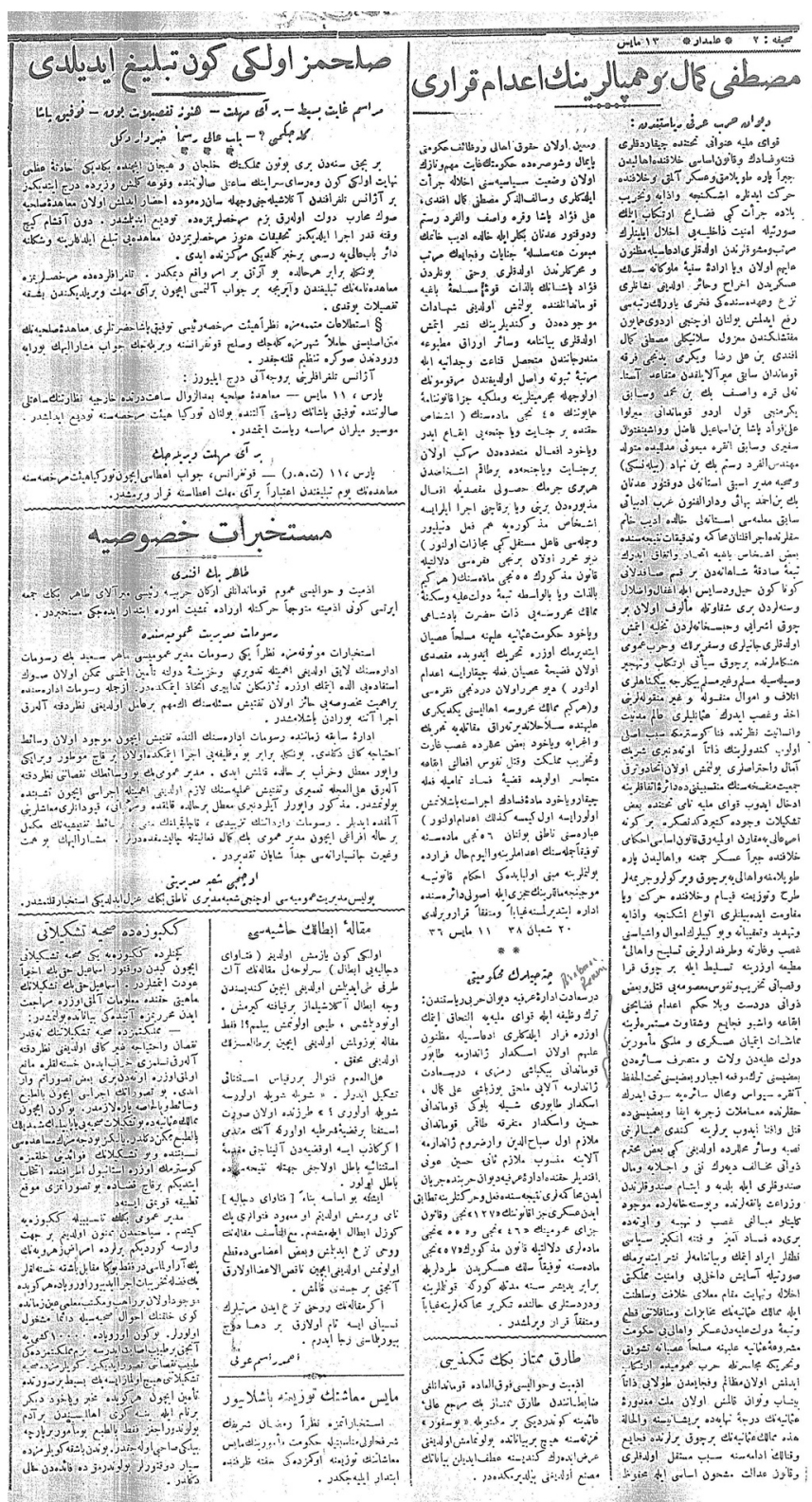

Alemdar, 13 May1s 1336/1920, Nr: 507-2816.

Mustafa Kemal Paşa ve arkadaşları hakkında 1. Divân-1 Harbi Örfi Riyaseti'nce verilen idam kararı. 


\section{EK-5}

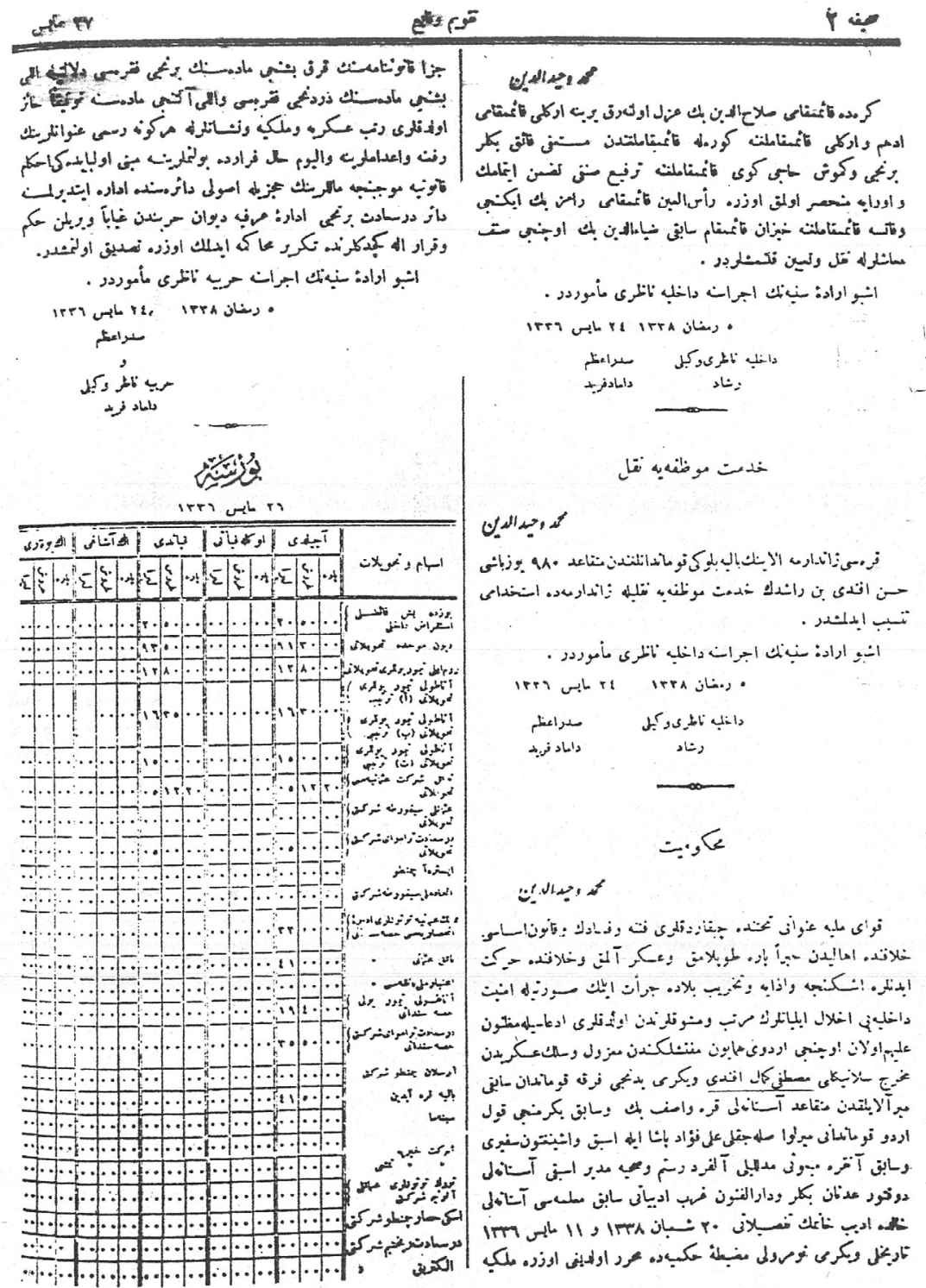

Takvim-i Vekâyi, 27 Mayıs 1336/1920, Nr: 3864.

Mustafa Kemal Paşa ve arkadaşları hakkında 1. Divân-1 Harbi Örfi Riyaseti'nce verilen idam kararının Sultan Vahdettin tarafından onaylandığını gösteren İrade-i Seniyye sureti. 


\section{EK 6}

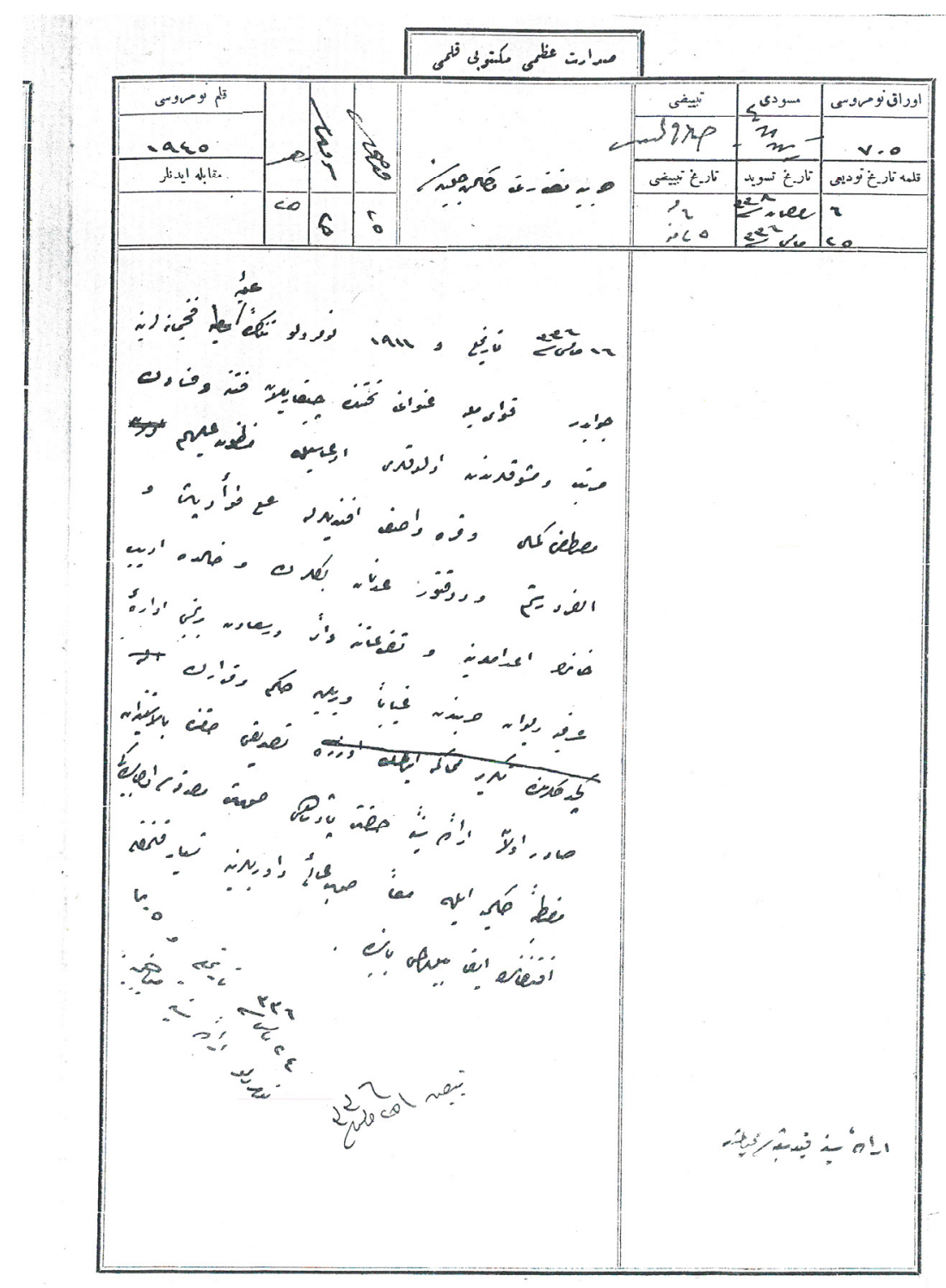

BOA, BEO. Umumî No: 347564

Mustafa Kemal paşa ve arkadaşlarının idam cezasına çarptırılmaları hakkındaki Divan-1 Harbi Örfi kararı ve İrade-i Seniyye ile onayının Harbiye Nezareti tarafından gereğinin yapılması hakkında belge. 


\section{EK-7}

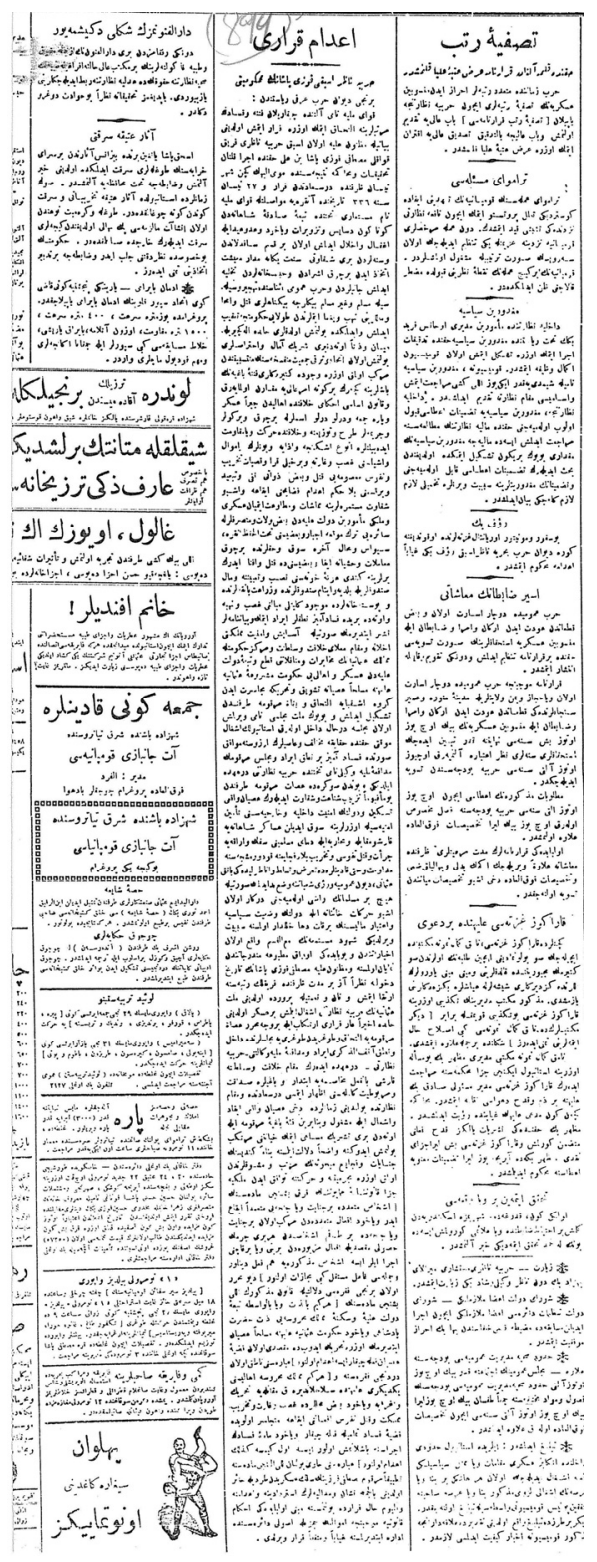

Vakit, 26 Mayıs 1336/1920, Nr: 899.

Mareşal Fevzi Çakmak hakkında 1. Divân-1 Harbi Örfi tarafından verilen idam kararı. 


\section{EK-8}

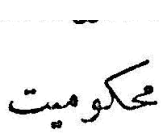

\section{نمان}

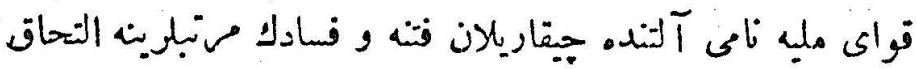

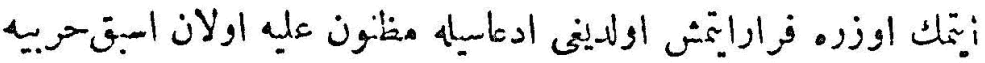

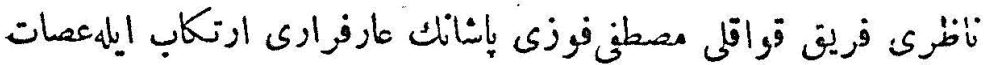

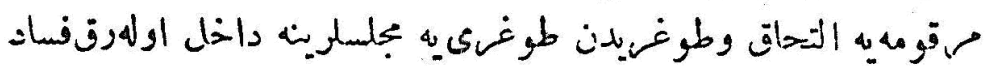

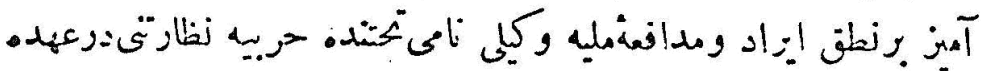

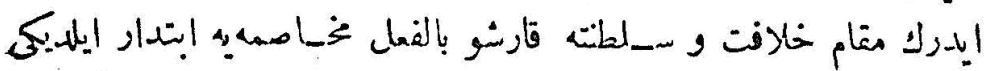

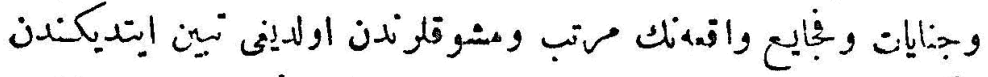

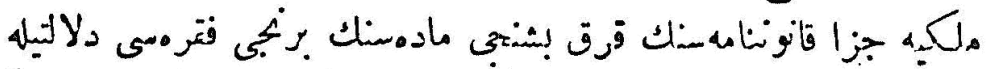

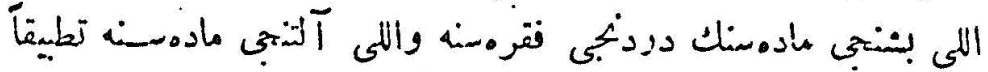

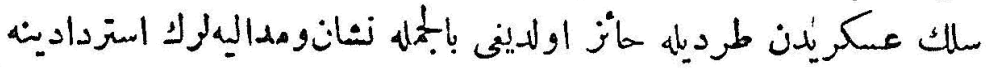

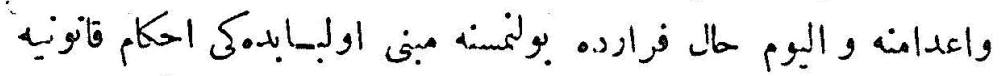

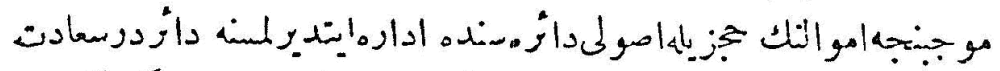

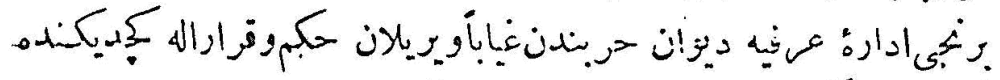

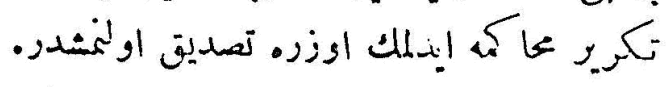

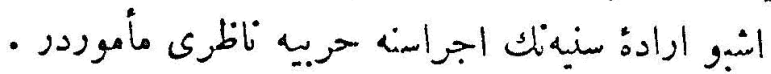

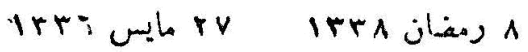

صدراعظم

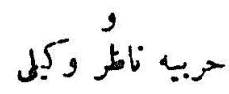

دالماد فريد وكل

Takvim-i Vekâyi, 30 Mayıs 1336/1920, Nr: 3600.

Mareşal Fevzi Çakmak hakkında verilen idam kararının Sultan Vahdettin tarafından onaylandığını gösterir İrade-i Seniyye sureti. 
EK-9

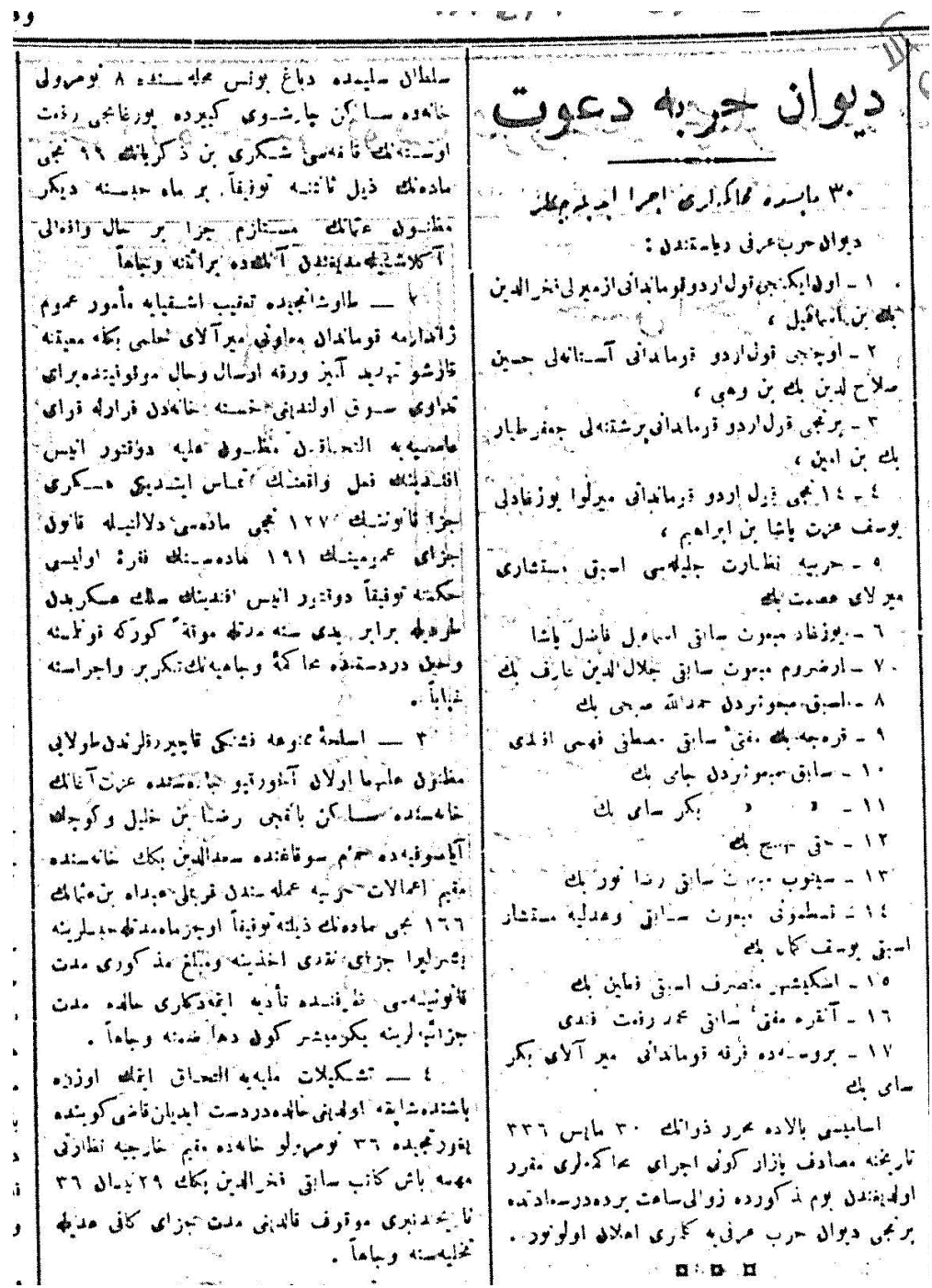

Vakit, 25 Mayıs 1336/1920, Nr: 898.

Kuvâ-yı Milliye'nin önde gelenlerinden İsmet İnönü, Celalettin Arif ve diğerlerinin (17 kişilik liste) Divân-1 harbe icabet etmeleri yönünde Vakit gazetesinde çıan haber. 
EK-10

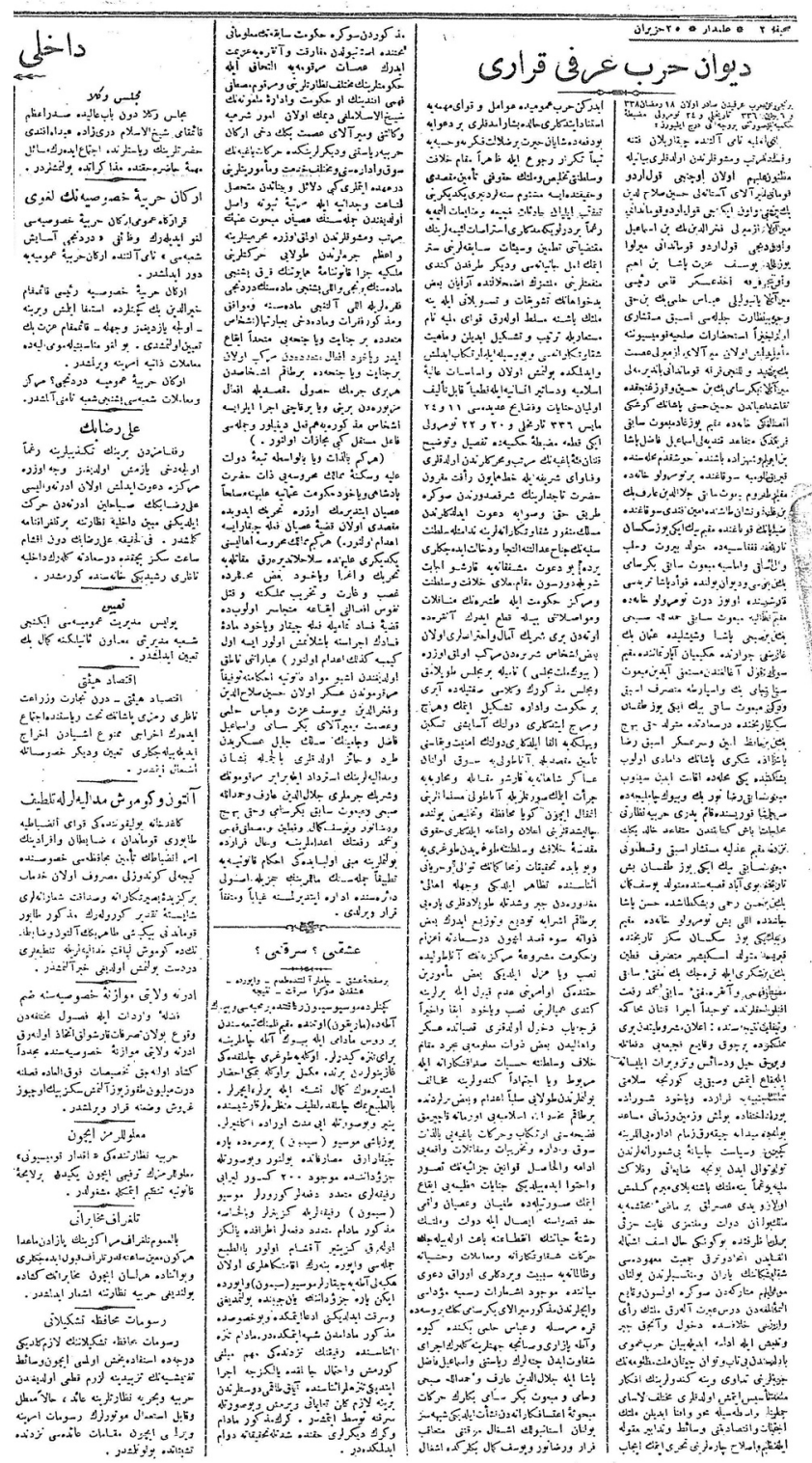

Alemdar, 25 Haziran 1336/1920, Nr: 549-2859.

Kuvâ-yı Milliye'nin önde gelenlerinden İsmet İnönü, Celalettin Arif ve diğerleri (17 kişilik liste) hakkında 1. Divân-1 Harbi Örfi Riyaseti’nce verilen idam kararı. 


\section{EK-11}

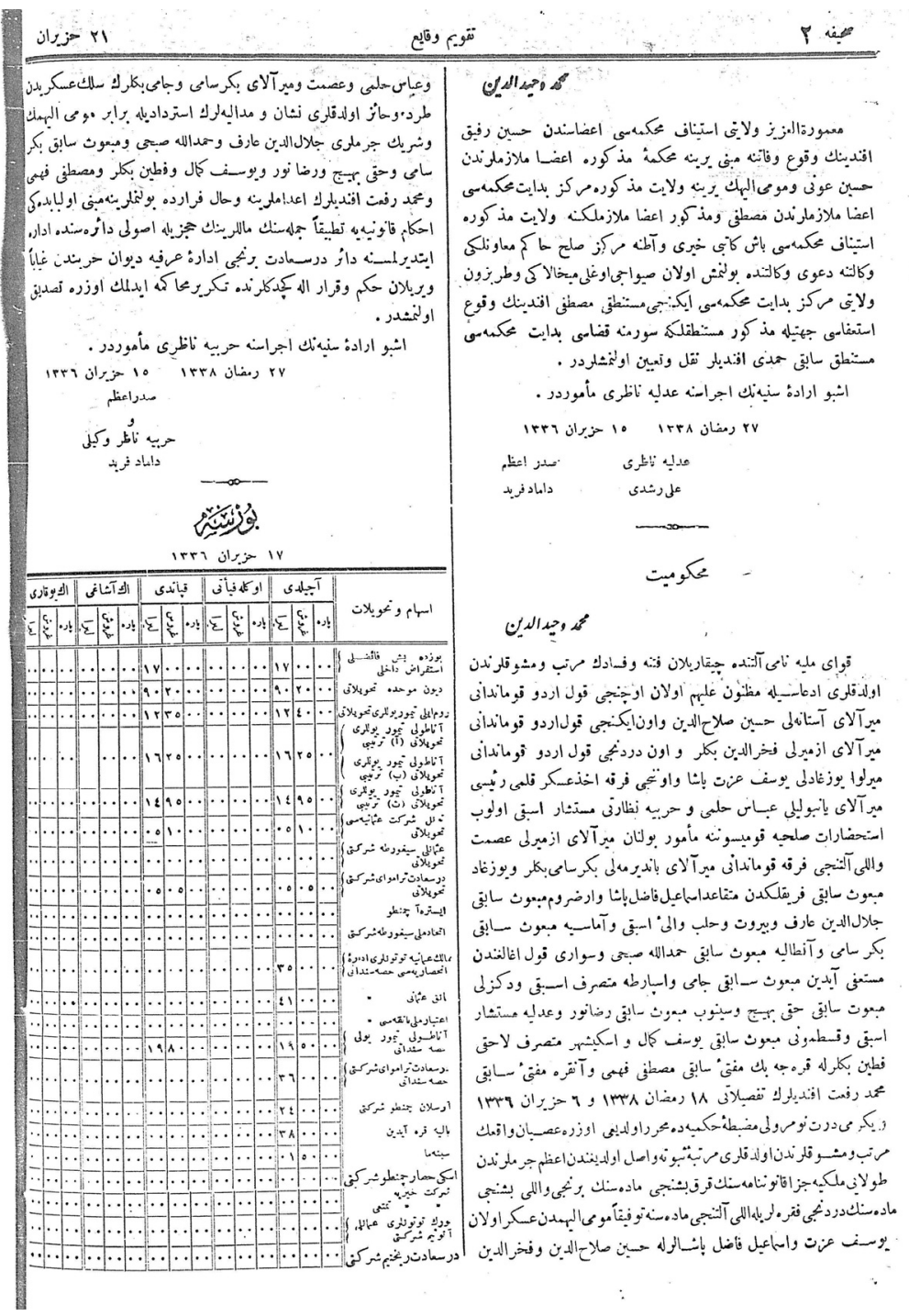

Takvim-i Vekayi, 21 Haziran 1336/1920, Nr: 3883.

Kuvâ-yı Milliye'nin önde gelenlerinden İsmet İnönü, Celalettin Arif ve diğerleri (17 kişilik liste) hakkında 1. Divân-1 Harbi Örfi Riyaseti'nce verilen idam kararının Sultan Vahdettin tarafından onaylandığını gösterir İrade-i Seniyye sureti. 
EK 12

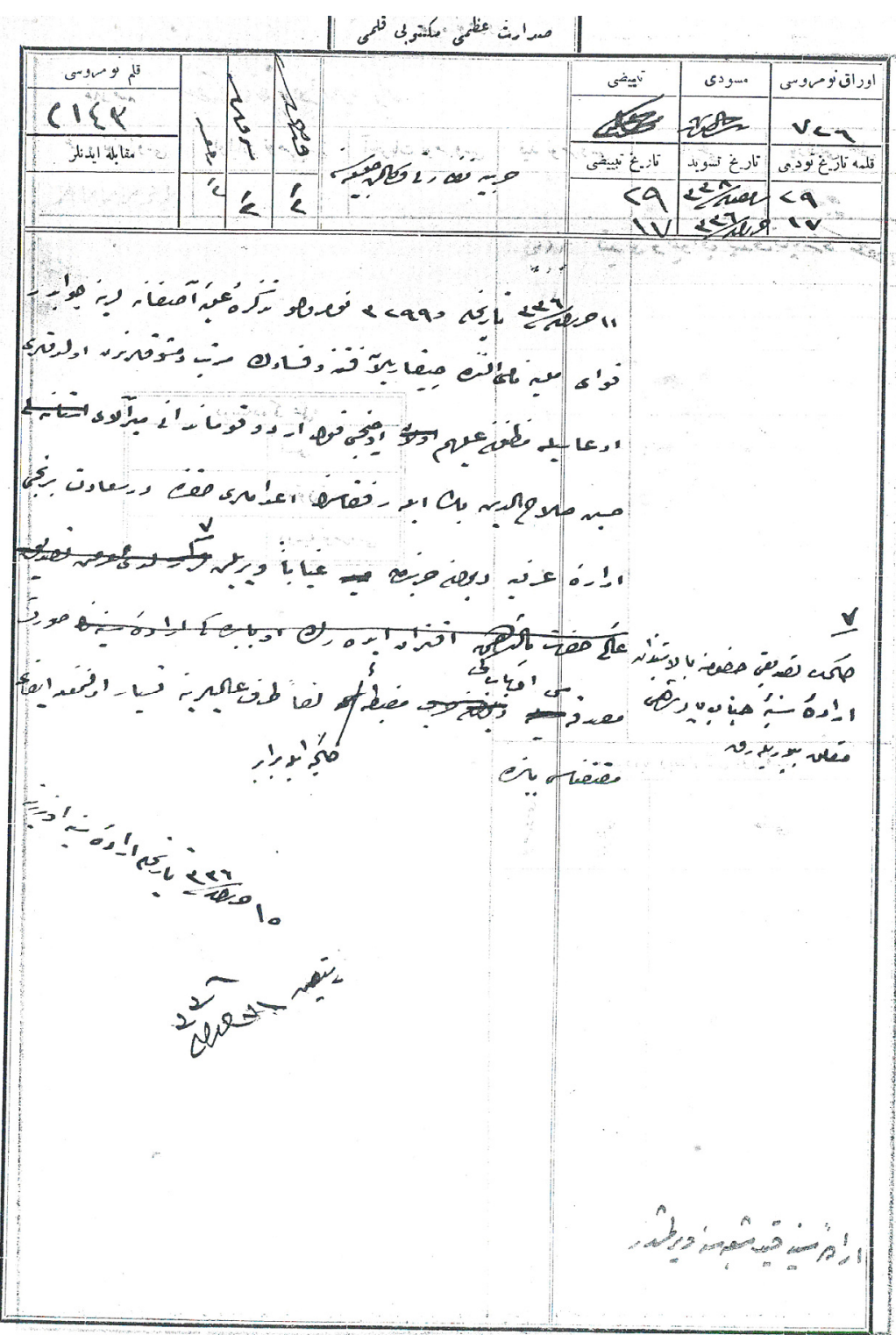

BOA, BEO. Umumî No: 347778

Miralay Hüseyin Selahattin Bey ile arkadaşlarının idam cezasına çarptırılmaları hakkındaki Divan-1 Harbi Örfi kararı ve İrade-i Seniyye ile onayının Harbiye Nezareti tarafından gereğinin yapılması hakkında belge. 


\section{EK 13}

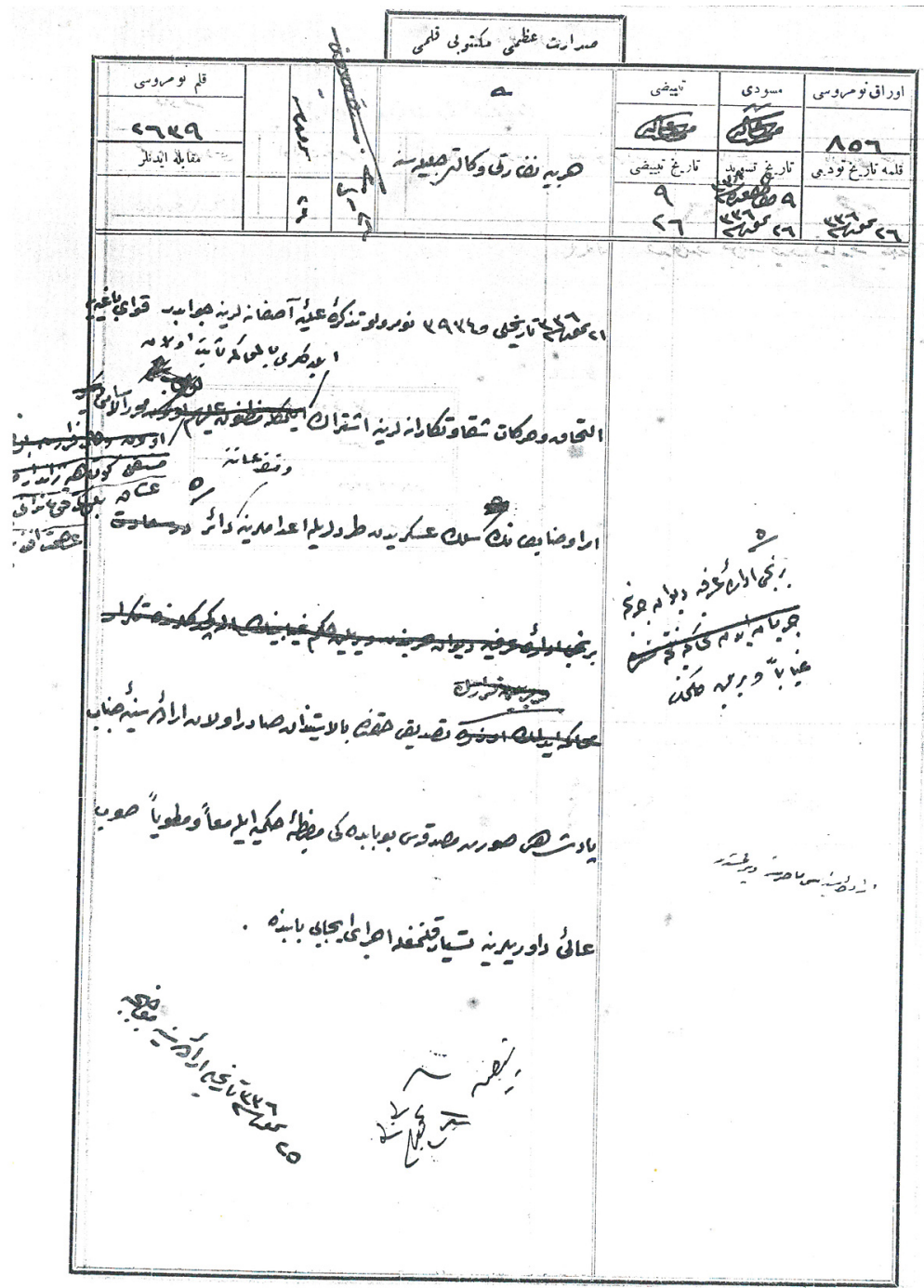

BOA, BEO. Umumî No: 348255

Kuvâ-yı Milliye hareketine katılan ve faaliyetlerde bulunan ümera ve zabitin hakkında askerlik mesleğinden ihraç ve idamlarına dair Divan-1 Harbi Örfi kararı ve

İrade-i Seniyye ile onayının Harbiye Nezareti tarafından gereğinin yapılması hakkında belge. 